\title{
9. LOW HYDROTHERMAL IMPACT IN VOLCANICLASTIC SEDIMENTS OF THE NORTH AOBA BASIN: SITES 832 AND $833^{1}$
}

\author{
Martine Gérard ${ }^{2}$ and Alain Person ${ }^{3}$
}

\begin{abstract}
Volcaniclastic sediments of North Aoba Basin (Vanuatu) recovered during Ocean Drilling Program (ODP) Leg 134 show a mineralogical and chemical overprint of low grade hydrothermal alteration superimposed on the primary magmatic source compositions. The purpose of this study was to identify authigenic mineral phases incorporated in the volcaniclastic sediments. to distinguish authigenic chemical and mineralogical signals from the original volcaniclastic mineralogical and chemical compositions, and to determine the mechanism of authigenic minerals formation.

Mineralogical, micro-chemical and bulk chemical analyses were utilized to identify and characterize authigenic phases and determine the original unaltered ash compositions. 117 volcaniclastic sediment samples from North Aoba Basin Sites 832 and 833 were analyzed. Primary volcaniclastic materials accumulated in North Aoba Basin can be divided into three types. The older basin-filling sequences show three different magmatic trends: high $\mathrm{K}$, calc-alkaline, and low $\mathrm{K}$ series. The most recent accumulations are rhyodacitic composition and can be attributed to Santa Maria or Aoba volcanic emissions.

Original depositional porosity of volcaniclastic sediments is an important factor in influencing distribution of authigenic phases. Finer-grained units are less altered and retain a bulk mineralogical and chemical composition close to the original pyroclastic rock composition. Coarser grained units (microbreccia and sandstones) are the major hosts of authigenic minerals. At both sites, authigenic minerals (including zeolites, clay minerals, Mg-carbonates, and quartz) exhibit complex zonation with depth that crosses original ash depositional boundaries and stratigraphic limits. The zeolite minerals phillipsite and analcime are ubiquitous throughout the altered intervals. At Site 832, the first zeolite minerals (phillipsite) occur in Pleistocene deposits as shallow as 146 meters below seafloor (mbsf). At Site 833 the first zeolite minerals (analcime) occur in Pleistocene deposits as shallow as $224 \mathrm{mbsf}$. The assemblage phillipsite + analcime + chabazite appears at $635 \mathrm{mbsf}$ (Site 832) and at $376 \mathrm{mbsf}$ (Site 833). Phillipsite + analcime + chabazite + thomsonite + heulandite are observed between 443 and 732 mbsf at Site 833. Thomsonite is no longer observed below $732 \mathrm{mbsf}$ at Site 833 . Heulandite is present to the base of the sections cored. The zeolite assemblages are associated with authigenic clay minerals (nontronite and saponite), calcite, and quartz. Chlorite is noticeable at Site 832 as deep as $851 \mathrm{mbsf}$. Zeolite zones are present but are less well defined at Site 832. Dolomite and rare magnesite are present below $940 \mathrm{~m}$ at Site 832.

The coarse-grained authigenic mineral host intervals exhibit geochemical signatures that can be attributed to low grade hydrothermal alteration. The altered intervals show evidence of $\mathrm{K}_{2} \mathrm{O}, \mathrm{CaO}$, and rare earth elements mobilization. When compared to fine-grained, unaltered units, and to Santa Maria Island volcanics rocks, the altered zones are relatively depleted in rare earth elements, with light rare earth elements-heavy rare earth elements fractionation.

Drilling at Site 833 penetrated a sill complex below $840 \mathrm{~m}$. No sill was encountered at Site 832. Complex zonation of zeolite facies, authigenic smectites, carbonates and quartz, and associated geochemical signatures are present at both sites. The mineralogical and chemical alteration overprint is most pronounced in the deeper sections at Site 832. Based on mineralogical and chemical evidence at two locations less than $50 \mathrm{~km}$ apart, there is vertical and lateral variation in alteration of the volcaniclastic sediments of North Aoba Basin. The alteration observed may be activated by sill intrusion and associated expulsion of heated fluids into intervals of greater porosity. Such spatial variation in alteration could be attributed to the evolution of the basin axis associated with subduction processes along the New Hebrides Trench.
\end{abstract}

\section{INTRODUCTION}

This study focused on volcaniclastic sediments recovered at sites 832 and 833 in the North Aoba Basin drilled during Ocean Drilling Program Leg 134. The purpose of this study was to examine the evolution of alteration of volcaniclastic sedimentary fill within North Aoba Basin, to determine the original volcaniclastic composition and how variation in original composition and texture influences distribution of authigenic mineral formation and authigenic mineralogical and chemical composition.

North Aoba Basin is a deep basin ( $>3000 \mathrm{~m}$ water depth) located in the central intra-arc basin of the New Hebrides Island Arc (NHIA), associated with the complex boundary between the Pacific and Australia-India plates in the Southwest Pacific (Fig. 1), where the Pacific plate subducts beneath the Australia-India plate. The North Aoba Basin is $50 \mathrm{~km}$ wide (east-west) and $80 \mathrm{~km}$ long (north-south). It is

\footnotetext{
${ }^{1}$ Greene, H.G., Collot, J.-Y., Stokking, L.B., et al., 1994. Proc. ODP, Sci. Results 134: College Station, TX (Ocean Drilling Program).

${ }^{2}$ ORSTOM, 70 route d'Aulnay, 93140 Bondy, France.

${ }^{3}$ Laboratoire de Géologie des Bassins Sédimentaires, Université Pierre et Marie Curie, 4 place Jussieu, 75252 Paris, France.
}

bordered on the west by Espiritu Santo Island, on the east by Maewo Island, on the north by Santa Maria Island, and on the south by Aoba Island. Petrological characteristics of Espiritu Santo island volcanic rocks are intermediate between arc tholeiite and calc-alkaline type lavas (Macfarlane et al., 1988). Upper Miocene to lower Pliocene lavas on Maewo Island are mainly high potassium basalts and basaltic andesites, which evolve to highly potassium calc-alkaline andesites (Mallick and Neef, 1974; Gorton, 1974). Aoba and Santa Maria islands are active shield volcanoes. Santa Maria and Aoba volcanoes produce picritic to rhyodacitic lavas suites (Gorton, 1977; Barsdell et al., 1982). Aoba volcano produces basic lavas of mainly potassic to ankaramitic basalt composition (Monjaret, 1989). On Santa Maria volcano, an oversaturated tholeiitic series coexists with an alkaline one (Gorton et al., 1977).

\section{Site 832}

Two holes were drilled at Site 832: Holes 832A and 832B, located in $3089 \mathrm{~m}$ water depth in the central part of the intra-arc basin (Fig. 1). $215.9 \mathrm{~m}$ of sediments were recovered in Hole $832 \mathrm{~A} ; 1106.7 \mathrm{~m}$ of sediments were recovered in Hole 832B (Fig. 2). Site 832 has been divided into seven lithostratigraphic units (Collot, Green, Stokking, 


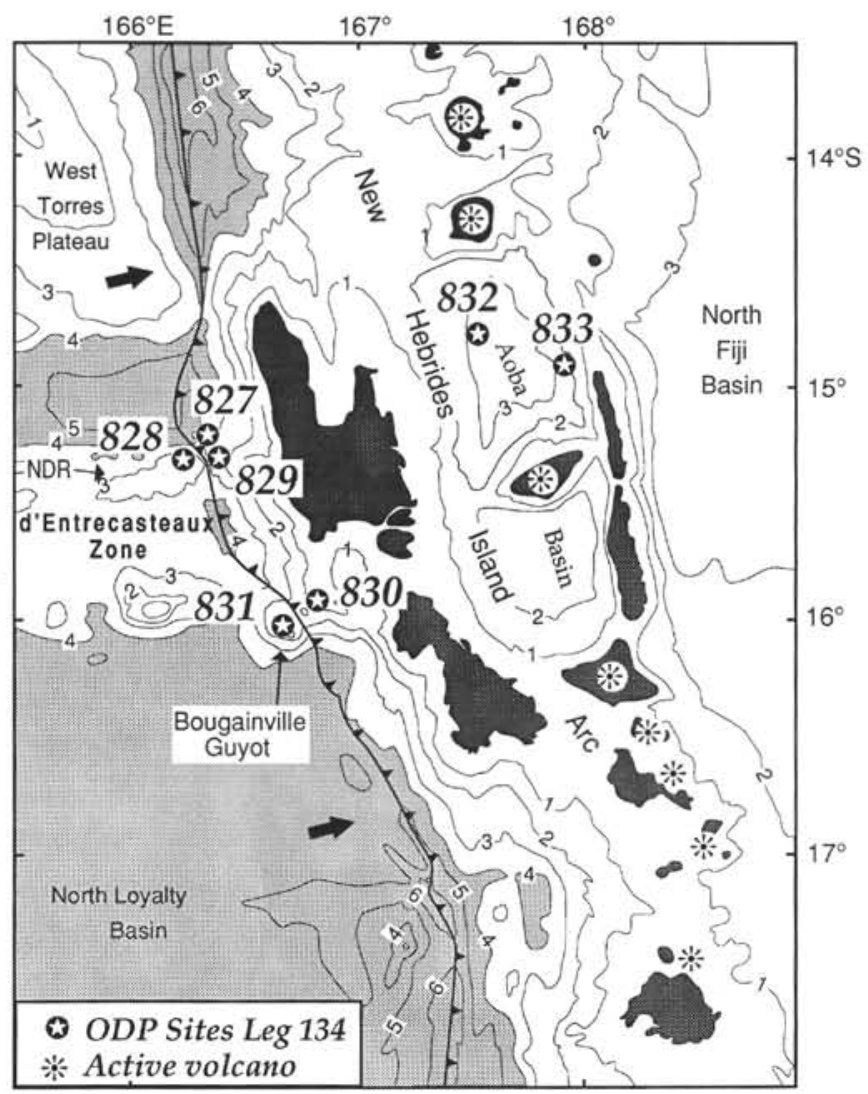

Figure 1. Location of Sites 832 and 833. Bathymetry in kilometers. NDR = North D'Entrecasteaux Ridge.

et al., 1992) (Fig. 2). These units are mainly volcanic (Units IA, IB, II, VI, and VII), or mainly biogenic calcareous (Units III and V).

Lithostratigraphic Unit I (Pleistocene; $385.6 \mathrm{~m}$ thick; 22 samples) consists of volcanic clays, silts and sands that are subdivided, on a granulometric basis, into two subunits. Subunit IA (141 m thick) is composed of unlithified coarse volcanic ashes interbedded with sandy to clayey volcanosedimentary silts with biogenic components. Subunit IB (244.6 m thick) is similar to Subunit IA but with finer vitric ashes.

Lithostratigraphic Unit II, between 385.6 and 461.5 mbsf is transitional (Pleistocene; $75.9 \mathrm{~m}$ thick; one sample). In the upper part, it consists of volcanic claystones to volcanic coarse-grained sandstones with sedimentary structures (laminae, burrow). The lower part of this unit contains more calcareous silty sandstones to silty claystones with foraminifers and nannofossils. Evidence of contorted lenses, laminae and slumps, and also sed-igneous sed-lithic breccias and basaltic breccias occur.

Lithostratigraphic Unit III, between 461.2 and 625.7 mbsf (early Pleistocene to late Pliocene; $164.2 \mathrm{~m}$ thick; eight samples) is more calcareous but contains interbedded volcanic sandstones, siltstones, and breccias or mixed sedimentary volcanic levels.

Lithostratigraphic Unit IV, between 625.7 and $702 \mathrm{mbsf}$ (late Pliocene to Pleistocene; 76.3 m thick; six samples), is composed of a major basaltic breccia, lithified volcanic sandstones, and siltstones. A major discontinuity is found at about $700 \mathrm{mbsf}$.

Lithostratigraphic Unit V, between 702 and 865.7 mbsf (upper Miocene to Pliocene; $163.7 \mathrm{~m}$ thick, three samples), contains biogenic calcareous silty limestones and clayey siltstones that overlie a basaltic breccia.

Lithostratigraphic Unit VI, between 865.7 and $952.6 \mathrm{mbsf}$ (middle to upper Miocene; $86.9 \mathrm{~m}$ thick; three samples) is a lithified volcanic sandstone grading downward to coarser material.
Lithostratigraphic Unit VII (early to middle Miocene at the top of the sequence; $154.1 \mathrm{~m}$ thick; ten samples) is composed of lithified basaltic breccias and volcanic sandstones and siltstones interbedded with vitric ashes.

\section{Site 833}

Two holes were drilled at Site 833: Holes 833A and 833B. Site 833 is located in $2628 \mathrm{~m}$ water depth, on the lower east slope of the North Aoba basin, approximately $24 \mathrm{~km}$ northwest of Maewo Island. Hole $833 \mathrm{~A}$ penetrated $199.5 \mathrm{~m}$ of sediment. Hole $833 \mathrm{~B}$ penetrated $1000.1 \mathrm{~m}$ of sediment and included a sill complex at the base of the cored section. Site 833 has been divided into five lithostratigraphic units (Collot, Green, Stokking, et al., 1992; Fig. 2).

Lithostratigraphic Unit I (late Pleistocene to Holocene; $84 \mathrm{~m}$ thick; six samples) consists of unlithified volcanic silts interbedded with coarse volcanic ashes. It is subdivided in two subunits. Subunit IA is enriched in carbonate content compare to the coarser Subunit IB.

Lithostratigraphic Unit II, between 77 and $375.8 \mathrm{mbsf}$ (late Pliocene to late Pleistocene/Holocene; $298.4 \mathrm{~m}$ thick; nine samples) is represented by calcareous siltstones and claystones highly bioturbated, with volcaniclastic levels.

Lithostratigraphic Unit III, between 375.8 and 577.8 mbsf (late Pliocene to early Pleistocene; $202 \mathrm{~m}$ thick; 35 samples), shows black coarse volcanic sandstones that are associated with basaltic breccias with low carbonate content .

Lithostratigraphic Unit IV, between 577.8 and 830.3 mbsf (early to late Pliocene; $252.5 \mathrm{~m}$ thick; 58 samples), shows black volcanic sandstones and siltstones that are interbedded with finer grained calcareous volcaniclastic sediments with fining-upward sequences.

Lithostratigraphic Unit V, between 830.3 and 1001.1 mbsf (early Pliocene sediments only; $170.8 \mathrm{~m}$ thick; nine samples) shows calcareous volcanic siltstones that are interbedded with basaltic middle Pliocene sills.

\section{METHODS}

Samples requested from Leg 134 for this study were aimed at acquisition of a very specific suite of samples. We wanted samples that could be used to investigate mineralogical and geochemical signals which retain a record of low-grade hydrothermal alteration of the volcaniclastic sediments. Thus, we needed examples of the original unaltered materials and examples of as many different authigenic minerals as possible. Our sampling strategy concentrated on two major petrographic facies: (1) microbreccia; and (2) volcanosedimentary sandstones, siltstones, and claystones. We chose to concentrate on these two facies because, based on shipboard observations, they contain primary volcanic elements and authigenic elements. The microbreccias are composed of various centimeter- to millimeter-sized lithoclasts (pumice, vesicular fragments, individual phenocrysts). Clasts within the volcanosedimentary units, regardless of clast size, contain primary volcanic elements (primary feldspars, vitric fragments, pyroxenes, and opaque minerals). The volcaniclastic units are interbedded with biogenic carbonate materials. Both the microbreccias and volcanosedimentary rock units contains secondary authigenic minerals. In the microbreccias, veinlets and vugs are filled with zeolites, calcite, and smectite. Primary porosity in the volcanosedimentary units has been filled in with zeolites, smectites, and secondary carbonates.

Prior to mineralogical and chemical analyses, all samples ( 53 from Site 832, 117 from Site 833) were ground with an agate mortar and pestle. Mineralogy was determined by X-ray diffraction (XRD) analyses of the bulk materials. Clay mineralogy was determined by XRD analyses of oriented air-dried, glycolated, and heated $\left(500^{\circ} \mathrm{C}\right.$ for $\left.4 \mathrm{hr}\right)$ materials. We used the Siemens X-ray diffractometer with Ni-filtered $\mathrm{CuK}$ alpha radiation, at $40 \mathrm{kv}$ and $30 \mathrm{~mA}$. The air-dried samples were scanned from $2^{\circ}$ to $70^{\circ} 2 \Theta$ at $0.03^{\circ} / 2 \mathrm{~s}$, with a rotating sample holder. A specific correction was made by microprocessor on the digitally 
Site 832

Volcanic sand/sandstone

Folcanic silt/siltstone

Volcanic sandstone/siltstone/claystone

Volcanic breccia

sill

도논 Nannofossil ooze

Foraminiferal chalk

도돔 Pelagic limestone

$\sim$ Unconformity

- - Ash
Site 833

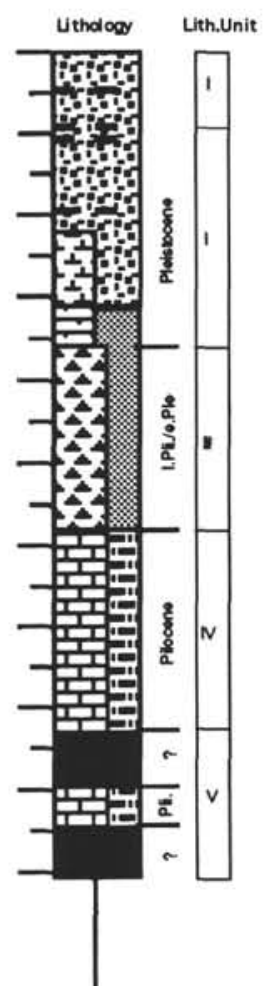

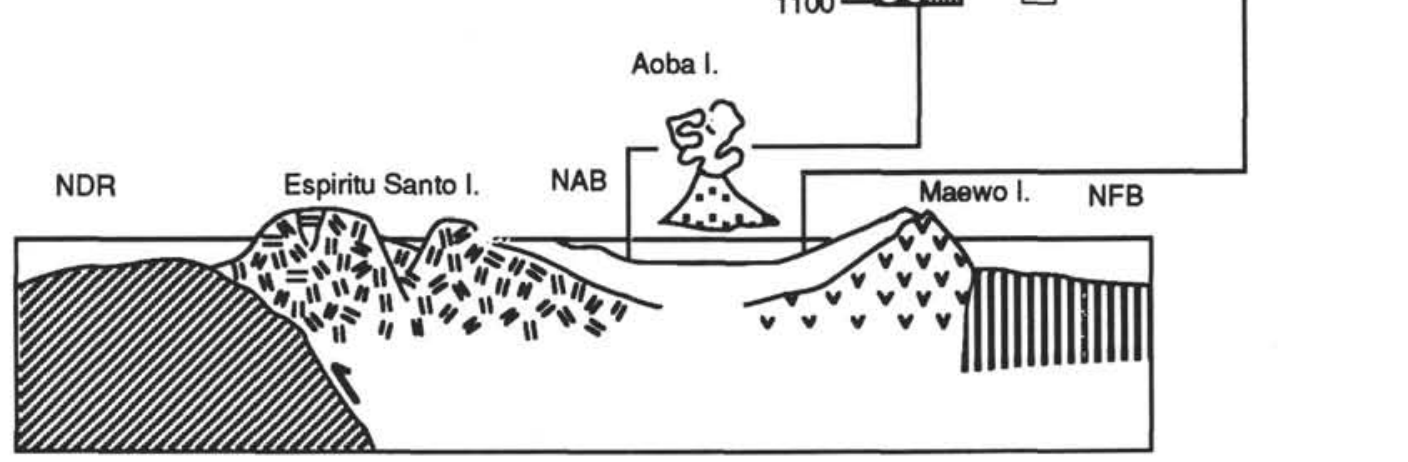

VIII Oceanic crust

Western Belt volcanic rocks

Evestern Belt volcanic rocks

\section{$\because$ Central Chain volcanic rocks}

Basin fill

Figure 2. Lithostratigraphy of Sites 832 and 833.

collected signal for the analcime peak, between 17 and $37^{\circ} 2 \Theta$, where amorphous components raised the background counts. We employed a semi-quantitative approach to determine relative abundance of single mineral phases present in various sediments samples. This technique is based on maximum peak intensity (in counts) of the major peak or the less perturbated peak, for the given minerals. "Peak" area was used to determine relative abundance of smectites, or vitric amorphous phase.
Based on petrographic and X-ray diffraction data, we chose the most interesting samples for further analyses. Micro-morphology and micro-chemical analyses were performed on selected samples using the Cambridge S-200 scanning electron microscope with energy dispersion spectra microprobe AN 10000 Link. Micro-analyses are qualitative when associated with micro-morphology or quantitative when using ZAF correction (Z: atomic number, A: absorption, F: fluorescence). 
Major and traces elements, and rare earth elements including Y, were analyzed for selected samples by induced coupled plasma at CRPG Nancy (seventeen samples from Site 832, twenty-seven samples from Site 833). Solids were put into solution using fluxed fusion with lithium metaborate and dissolution in dilutive acid. The limit of detection for trace elements was $5 \mathrm{mg} /$, with the following exceptions: Ga was $0.5 \mathrm{mg} / \mathrm{l}, \mathrm{Sc}$ and $\mathrm{Y}$ were $1 \mathrm{mg} /$, and REEs (rare earth elements) were 1 to 3 times the chondritic composition. $\mathrm{U}$ and $\mathrm{Th}$ were analyzed using solutions derived from fusion/dissolution of a separated solid subsample. Detection limits for $\mathrm{U}$ and $\mathrm{Th}$ were $0.1 \mathrm{mg} / \mathrm{l}$.

Total carbon was analyzed by elemental $\mathrm{CHN}$ analyzer at the Geochemistry Laboratory, ORSTOM Bondy. Relative $\mathrm{CO}_{2}, \mathrm{CaCO}_{3}$, and carbonate $\mathrm{CaO}$ were calculated from total carbon. Calculated $\mathrm{CaO}$ was subtracted from the analyzed bulk sample $\mathrm{CaO}$ to give total oxides on carbonate free basis.

\section{MINERALOGY}

\section{General}

Bulk sediment mineralogy can be divided into three basic types of components: primary volcanic components, authigenic minerals, and biogenic components. The primary volcanic components are constituted by a vitric part (pumice, glass shard) and lithic fragments. Primary volcanic minerals include feldspar, pyroxene, magnetite, and rarely, amphibole and biotite. Quartz is common. The quartz may be a primary mineral derived from rhyodacitic eruptions. Authigenic quartz is also observed as secondary vein filling material or as overgrowth of primary quartz. Authigenic components include phyllosilicate minerals (smectite, chlorite) and zeolite minerals. Sulfates (gypsum and anhydrite) and sulfide (pyrite) are present, but rare. Carbonates are observed as both biogenic carbonate phases and authigenic calcite, dolomite, and magnesite.

Halite was observed associated with sediments from the upper portions of the holes and can be attributed to precipitation from evaporation of interstitial water present at the time of sampling.

\section{Site 832}

Mineral occurrences vs. depth in the core, based on XRD analyses, are given in Table 1. Results of semi-quantitative micro-analyses for major components are related to lithostratigraphy in Figure 3.

\section{Vitric Components}

Various types of glass are present: vesicular glass shards, agglomerated vitric particles, pumices, cuspate or platy shards (in accordance with the nomenclature of Fisher and Schmincke, 1984). Micromorphology of vitric components observed with SEM (Scanning Electronic Microprobe) are presented in Plate 1A. In Sample 134-832A$18 \mathrm{H}-1,32-34 \mathrm{~cm}, 131.82 \mathrm{mbsf}$, located at the base of the Subunit 1A, the glass occurs as agglomerated vitric particles. In Sample 134-832A$18 \mathrm{H}-1,85-87 \mathrm{~cm}, 141.85 \mathrm{mbsf}$, located at the top of the Subunit 1B, the vitric phase is characterized by vesicular glass shards and pumices. The chemical compositions of these glasses (Table 2) range between andesites and dacite/rhyodacite. In Unit 1, vitric components are fresh. Below this unit they are commonly altered in palagonite.

\section{Primary Volcanic Minerals}

Pyroxene, which represents the well crystallized volcaniclastic phase, is anticorrelated with the vitric phase (Fig. 3). Plagioclase shows approximately the same trends as pyroxene except two intervals: Unit 5, below $700 \mathrm{mbsf}$, where pyroxenes do not occur, and Unit 7 below 1020 mbsf. Based on XRD and microprobe chemical analysis, plagioclase compositions range between labradorite $\left(\mathrm{An}_{50-70}\right)$ and bytownite $\left(\mathrm{An}_{70-90}\right)$, which is compatible with petrological data obtained by Monjaret (1989).
Amphibole is not abundant (Table 1). Five samples show noticeable XRD peaks: 134-832B-23R-3, 42-44 cm; -44R-1, 117-119 cm; $-51 \mathrm{R}-1,26-28 \mathrm{~cm}$; $-67 \mathrm{R}-2,112-114 \mathrm{~cm}$; and $-74 \mathrm{R}-3,140-142 \mathrm{~cm}$. Above $357 \mathrm{mbsf}$ and below $893 \mathrm{mbsf}$, amphibole peaks are not observed on XRD data.

\section{Primary Volcanic Minerals or Authigenic Minerals}

Volcanic Fe-oxides are predominately magnetite in the upper part and titanomagnetite in the lower part of the hole. Authigenic Fe oxides exhibit typical micro-morphology: rosette shape (PI. 1B) or vug cover (Pl. 1B). The rosette shape of oxy-hydroxides is characteristic of $\mathrm{Fe}-\mathrm{Mn}$ enriched solution deposits associated with deuteric alteration of volcanic material (Person and Melières, 1978). The vug cover micromorphology was already observed on recent hydrothermal deposits of Teahitia active submarine volcano (Hoffert et al., 1987).

Quartz is nearly ubiquitous throughout the cores but shows variable distribution downcore (Fig. 3). Two quartz-rich intervals are situated at $781.22 \mathrm{mbsf}$ and $850.80 \mathrm{mbsf}$. The greatest abundance of quartz is in Sample 134-832B-74R-3, 140-142 cm (850.80 mbsf), an unconsolidated volcanic clayey siltstone. Quartz appears in intervals of clayey siltstone to siltstone, which are not well consolidated and the zeolitic cement is poorly developed. These enriched quartz levels may be derived from rhyodacitic eruptions. Some intervals display also volcanic quartz with authigenic overgrowth. In the fine grain-size fraction of sediment, small euhedral crystals of quartz are noticeable. Below 994 mbsf, quartz is not present on XRD data.

\section{Authigenic Minerals \\ Smectites}

Smectite occurs in relatively low abundance at 118.86 and 164.39 mbsf probably derived from surrounding onshore weathering. Higher smectites abundances appear at 270, 59 mbsf (Sample 134-832B14R-1, 89-91 cm). Smectites and vitric fragments, below this level are roughly anticorrelated (Fig. 3 ). These smectites coexist with the zeolitized intervals.

Based on 060 XRD peak position at $1.52 \AA-1.53 \AA$ (Desprairies, $1983)$ these smectites are trioctahedral $(1.52 \AA-1.53 \AA)$ or nontronites (1.51 $\AA-1.52 \AA)$. Microprobe analysis were realized on authigenic clay minerals characterized by lamellar shape (PI. 2). These smectites are $\mathrm{Mg}$ and $\mathrm{Fe}$ bearing ( $\mathrm{Fe}$-saponite) or $\mathrm{Fe}$ bearing (nontronite). At the bottom of the hole (Sample 134-832B-100R-4, 42-44 cm), two species of smectites coexist: trioctahedral ( 060 at $1.53 \AA$ ) and dioctahedral $(060$ at $1.49 \AA)$. Micro-probe analysis show that $\mathrm{Mg}$-smectites (saponite) coexist with Al-Fe smectite (beidellite).

Authigenic character of these smectites shows two typical micromorphologies. One type is a well shaped lamellar smectite (Pl. 1B) that grows in vug covers or flower structures (Pl. 3A). These lamellar smectites are also developed in the hart of Fe-oxyhydroxides tubules. Another type is a vermicular shape smectite associated with a globular form (Pl. 2). These two shapes are sometimes associated and then display a spatial distribution. The lamellar smectite is developed in a "central state" such as in structures associated with the primary porosity (vugs, veins). The vermicular smectite growths in a "peripherical state" such as border of vugs.

\section{Minor Authigenic Minerals}

Gypsum, pyrite, leucoxene, rare chlorite are the authigenic accessory minerals ( $\mathrm{Pl}$. 2). Leucoxene ( $\mathrm{Si}-\mathrm{Ca}-\mathrm{Ti}$ phase) is a common secondary phase in palagonitic and zeolitized shards of altered volcaniclastic rocks (Viereck et al., 1986). Pyrite is framboidal, suggesting recent formation in anaerobic sediments. Framboidal habit is characteristic of diagenetic origin (Schallreuter, 1984; Al-Aasm and Blaise, 1991). Some samples with cubic euhedral pyrite in the thin fraction of the sediment were noticed (Sample 134-832B-74R-3, 40-42 cm). Chlorite, which occurs in Sample 134-832B-74R-3, $140-142 \mathrm{~cm}, 850.80 \mathrm{mbsf}$, is associated with Mg smectites (Fig. 4) 
Table 1. Mineralogical occurrence and distritbution in Holes 832A and 832B.

\begin{tabular}{|c|c|c|c|c|c|c|c|c|c|c|c|c|c|c|c|c|c|c|}
\hline Unit & Sample (cm) & $\begin{array}{l}\text { Depth } \\
\text { (mbsf) }\end{array}$ & Phillipsite & Analcime & Chabazite & Thomsonite & Heulandite & Erionite & Smectite & Halite & Quartz & Calcite & Dolomite & $\begin{array}{c}\text { Rare } \\
\text { occurrence }\end{array}$ & Plagioclase & Pyroxene & Amphibole & Magnetite \\
\hline & 134-832A- & & & & & & & & & & & & & & & & & \\
\hline IA & $1 \mathrm{H}-1,35-37$ & 0.35 & & & & & & & & + & + & + & & & + & + & & + \\
\hline IA & $2 \mathrm{H}-2,6-8$ & 7.4 & & & & & & & & + & + & + & & & + & + & & + \\
\hline IA & $2 \mathrm{H}-6,14-16$ & 13.54 & & & & & & & & + & + & + & & & + & + & & + \\
\hline IA & $3 \mathrm{H}-1,16-18$ & 18.56 & & & & & & & & + & & + & & & + & + & & + \\
\hline AA & $12 \mathrm{H}-4,66-68$ & 96.66 & & & & & & & & + & & + & & & + & + & & + \\
\hline IA & $15 \mathrm{H}-2,100-102$ & 109.00 & & & & & & & & + & + & + & & & + & + & & + \\
\hline IA & $16 \mathrm{H}-1,98-100$ & 116.98 & & & & & & & & + & 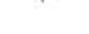 & + & & & + & + & & + \\
\hline IA & $16 \mathrm{H}-2,136-138$ & 118.86 & & & & & & & + & + & & + & & & + & + & & + \\
\hline IA & $18 \mathrm{H}-1,32-34$ & 131.82 & & & & & & & & + & + & + & & & + & + & & \\
\hline IA & $18 \mathrm{H}-2,32-34$ & 133.32 & & & & & & & & + & + & + & & & + & . & & + \\
\hline IA & $18 \mathrm{H}-3,32-34$ & 134.32 & & & & & & & & + & + & + & & & + & & & + \\
\hline $1 \mathrm{~A}$ & $18 \mathrm{H}-4,32-34$ & 136.32 & & & & & & & & + & + & + & & & + & + & & + \\
\hline IA & $18 \mathrm{H}-5,32-34$ & 137.82 & & & & & & & & + & + & + & & & + & + & & + \\
\hline IB & $19 \mathrm{H}-1,85-87$ & 141.85 & & & & & & & & + & + & + & & & + & 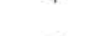 & & 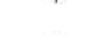 \\
\hline IB & $20 \mathrm{H}-2,39-41$ & 146.89 & + & & & & & & & + & + & . & & & + & + & & + \\
\hline & 134-832B- & & & & & & & & & & & & & & & & & \\
\hline IB & $3 \mathrm{R}-1,59-61$ & 164.39 & & & & & & & + & + & + & + & & & + & + & & \\
\hline IB & $7 \mathrm{R}-1,59-61$ & 202.79 & & & & & & & & + & + & + & & & + & & & \\
\hline 1B & $14 \mathrm{R}-1,89-91$ & 270.59 & & & & & & & + & + & + & + & & & + & + & & + \\
\hline IB & $19 \mathrm{R}-1,17-19$ & 318.27 & + & & & & & & + & + & + & + & & & + & + & & + \\
\hline $1 \mathrm{~B}$ & $22 \mathrm{R}-1,23-25$ & 347.13 & + & & & & + & & + & + & + & + & & & + & + & & + \\
\hline IB & $23 \mathrm{R}-1,70-72$ & 357.3 & & & & & & & . & + & + & + & & & + & + & & + \\
\hline IB & $23 R-3,42-44$ & 360.02 & + & & & & + & & + & + & + & + & & & + & + & + & + \\
\hline 2 & $30 \mathrm{R}-3,88-90$ & 427.48 & + & + & & & & & + & + & + & + & & & + & + & . & + \\
\hline 3 & $36 \mathrm{R}-1,108-110$ & 481.88 & + & & & & & & 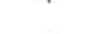 & + & $r$ & + & & & + & + & & + \\
\hline 3 & $36 \mathrm{R}-1,158-160 \mathrm{~A}$ & 482.88 & + & + & & & & & + & + & + & + & & Gypsum & + & + & + & + \\
\hline 3 & $36 \mathrm{R}-1,158-160 \mathrm{~B}$ & 482.9 & + & 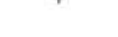 & & & & & + & + & $r$ & it & & 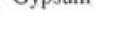 & + & + & + & + \\
\hline 3 & $36 \mathrm{R}-1,158-160 \mathrm{C}$ & 482.92 & 4 & & & & & & + & + & & & & & + & + & + & 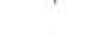 \\
\hline 3 & $36 \mathrm{R}-2,68-70$ & 482.98 & + & + & & & & & + & + & + & + & & & + & + & + & + \\
\hline 3 & $39 \mathrm{R}-2,91-93$ & 512.21 & + & + & & & & & + & T & + & + & & & + & + & 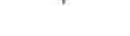 & + \\
\hline 3 & $40 \mathrm{R}-2,23-25$ & 521.23 & + & + & & & & & + & & + & $\begin{array}{l}+ \\
+\end{array}$ & & & + & + & & + \\
\hline 3 & $44 \mathrm{R}-1,117-119$ & 559.37 & + & & & & + & & + & & & + & & & + & + & + & + \\
\hline 4 & $51 \mathrm{R}-1,26-28$ & 625.96 & + & & & & & & + & & + & + & & & + & + & + & + \\
\hline 4 & $52 \mathrm{R}-1(\mathrm{~A}), 35-37$ & 635.65 & + & + & + & & & & + & & & + & & & + & + & & + \\
\hline 4 & $52 \mathrm{R}-1(\mathrm{~B}), 115-117$ & 636.45 & + & + & + & & & & + & & & & & & + & + & & + \\
\hline 4 & $52 \mathrm{R}-3,25-27$ & 638.61 & + & + & + & & & & + & & + & & & & + & + & & + \\
\hline 4 & $55 \mathrm{R}-2,141-143$ & 667.31 & + & + & + & & & & + & & + & & & & + & + & & + \\
\hline $\begin{array}{l}4 \\
4\end{array}$ & $58 \mathrm{R}-2,37-39$ & 694.17 & + & + & + & + & & & + & & + & & & & + & + & & + \\
\hline 5 & $59 \mathrm{R}-6,120-122$ & 710.71 & & & & & & & + & & + & + & & & + & + & & + \\
\hline 5 & $67 \mathrm{R}-2,112-114$ & 781.22 & + & + & & & + & & + & & + & + & & Gypsum & + & & + & + \\
\hline 5 & $74 \mathrm{R}-3,140-142$ & 850.8 & + & & + & & + & & + & & + & + & & Chlorite & + & & + & + \\
\hline 6 & $78 \mathrm{R}-6,122-124$ & 893.65 & + & & & + & & + & + & & & + & + & & + & + & & + \\
\hline 6 & $83 R-3,69-71$ & 936.99 & + & & & & + & & + & & + & + & + & & + & + & & + \\
\hline 6 & $84 \mathrm{R}-1,14-16$ & 943.04 & + & & & & + & & + & & + & & & & + & & & \\
\hline 7 & $85 \mathrm{R}-4,17-19$ & 957.27 & + & & & & + & & + & & + & + & & & + & & & + \\
\hline 7 & $86 \mathrm{R}-2,71-73$ & 977.91 & + & & & & & & + & & + & + & + & & + & + & & + \\
\hline 7 & $89 \mathrm{R}-3,105-107$ & 994.85 & + & + & + & & + & + & + & & + & + & + & & + & + & & + \\
\hline 7 & $90 \mathrm{R}-2,122-124$ & 1003.13 & + & + & + & & & + & + & & & + & & & + & + & & \\
\hline 7 & $91 \mathrm{R}-2,98-100$ & 1012.58 & + & + & & & + & & + & & + & + & + & & + & + & & + \\
\hline 7 & $92 \mathrm{R}-2,52-54$ & 1021.67 & + & + & & & + & & + & & & + & + & & + & + & & + \\
\hline 7 & $94 \mathrm{R}-2,102-104$ & 1041.52 & + & + & + & & & & + & & & + & + & Magnesite & + & + & & + \\
\hline 7 & $98 \mathrm{R}-2,121-123$ & 1080.41 & + & + & + & & & & + & & & r & + & (20) & + & + & & + \\
\hline 7 & $99 \mathrm{R}-1,43-45$ & 1087.73 & + & + & + & & & & + & & & & 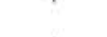 & & + & + & & + \\
\hline 7 & $100 \mathrm{R}-4,42-44$ & 1101.92 & + & & & & + & + & + & & & + & + & & + & + & & + \\
\hline
\end{tabular}



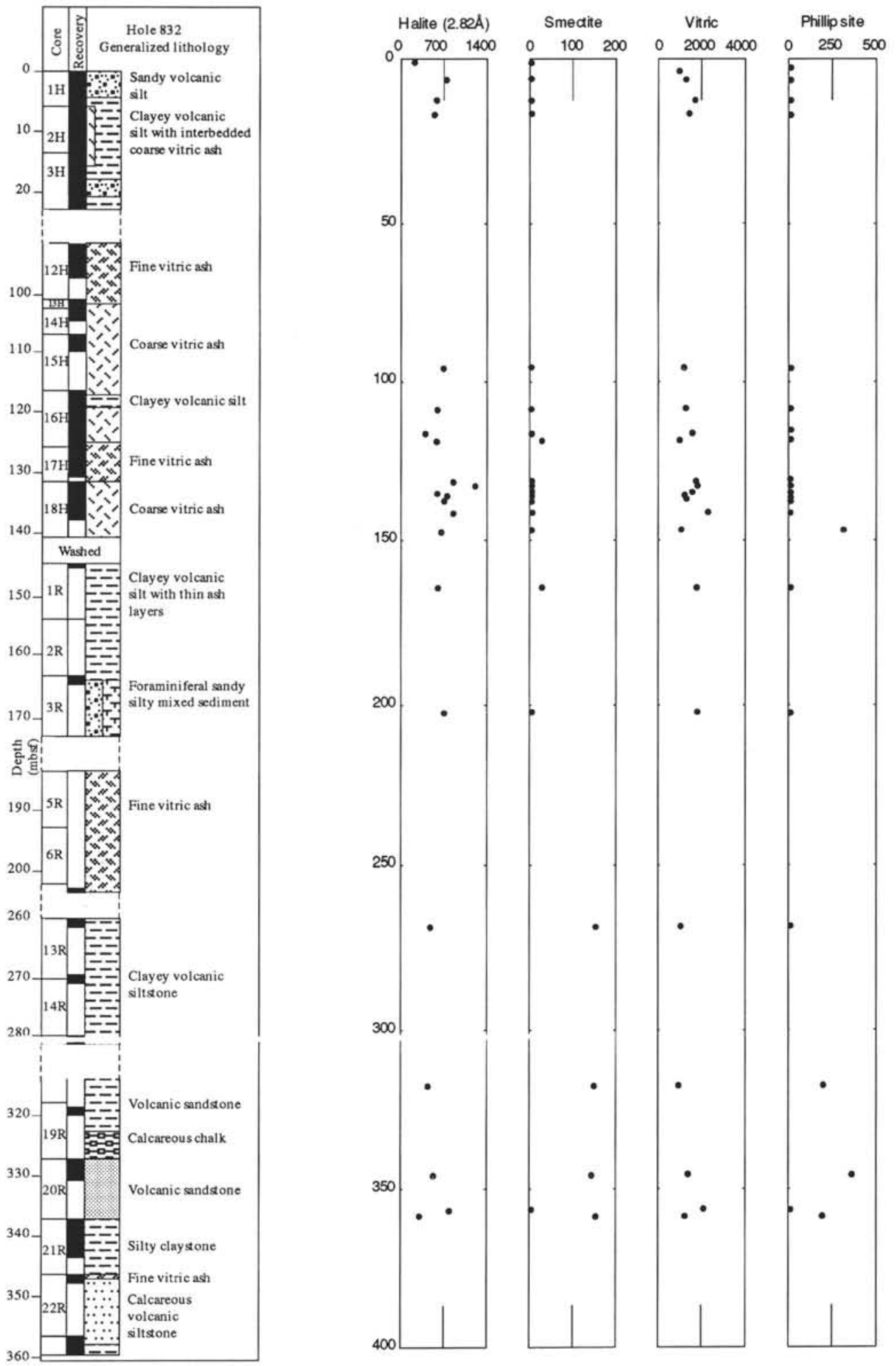

Figure 3. Mineralogical logs of the major phases, associated with lithostratigraphic column, Site 832. Logs vs. depth are a semiquantitative representation (in arbitrary units:counts). The semiquantitative data are relative to evolution of each mineral phases, with depth. But the abundance content of two different phases are not numerically comparable. This representation gives global trends of the evolution of the different phases. 

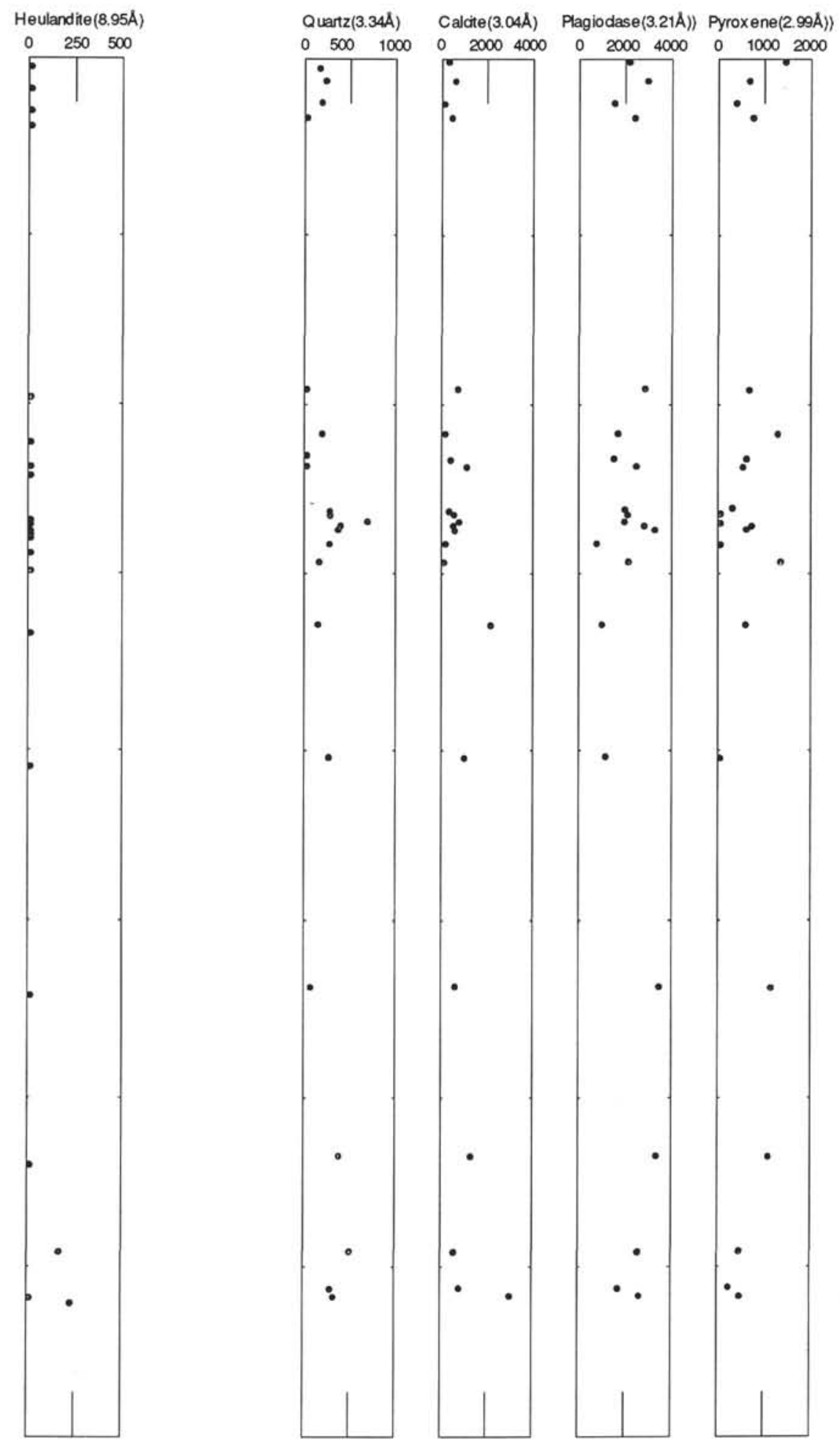

Figure 3 (continued).

and the zeolite minerals phillipsite, chabazite, and heulandite. This mineral assemblage indicates more intense hydrothermal alteration within this interval of volcaniclastic material.

\section{Zeolites}

Six major zeolitic minerals have been determined from XRD data and microprobe analysis. In order of occurrence they are phillipsite, analcime, chabazite, thomsonite, heulandite, and erionite. Their prin- cipal characteristics are summarized in Table 3, after Gottardi and Galli (1985). SEM micromorphology studies of these zeolites (Pls. 4, 5 , and 6) indicate current euhedral habits (Mumpton and Ormsby, 1978; Gottardi and Galli, 1985). Figures 5 to 8 show some XRD spectra of the zeolites determined in Sites 832 and 833. To distinguish heulandite from clinoptilolite, the test of Mumpton (overnight heating at $450^{\circ} \mathrm{C}$ ) was utilized. Heulandite is destroyed, but clinoptilolite is not, by this procedure. 


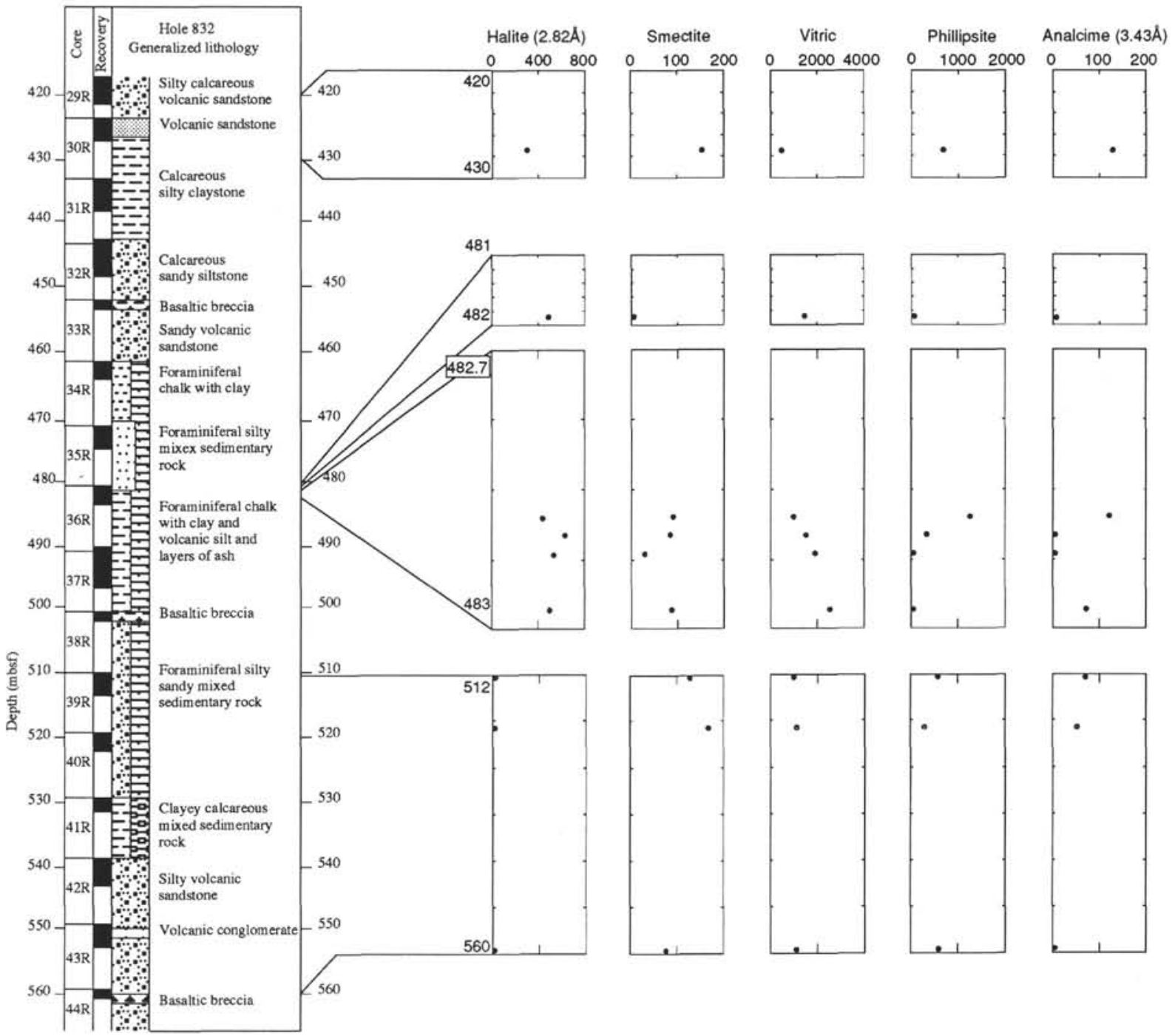

Figure 3 (continued).

Of the 53 samples studied, 32 are zeolite bearing. 11 zeolite assemblages are described with their occurrence frequencies in Table 4. The most frequently observed assemblage is phillipsite, analcime, chabazite. Phillipsite is ubiquitous in the zeolites bearing samples. It first occurs at $146.49 \mathrm{mbsf}$ in Unit 1B. The phillipsite-heulandite assemblage appears deeper in Unit 1B (Sample 134-832B-22R-1, $23-25 \mathrm{~cm}, 347.13 \mathrm{mbsf}$ ). Analcime associated with phillipsite first occurs in Sample 134-832B-30R-3, 88-90 cm, 427.48 mbsf, Unit 2. Chabazite associated with phillipsite plus analcime first occurs in Sample 134-832B-52R-1, 35-37 cm, 635.65 mbsf, Unit 4. The next zeolite added is thomsonite in phillipsite, analcime, chabazite assemblage in Sample 134-832B-58R-2, 37-39 cm, 694.17 mbsf, Unit 4. Erionite associated with phillipsite and thomsonite appears in Sample 134-832B-78R-6, 122-124 cm, 893.65 mbsf, Unit 6.

In a very small single sample scale, Sample 134-832B-36R-1, 158-164 cm, we distinguished three facies (Fig. 9). (In the following description, volcaniclastic minerals are not taken in account.) Facies $\mathrm{A}$ is a creamy siltstone with scarce black vitric particles. Facies A has the greatest abundance of phillipsite (of our sampling) in Hole 832B, and also contains analcime, quartz, calcite, gypsum, and rare smectites. Facies B is a dark beige siltstone with black vitric particles. Facies B contains relatively low abundance of smectites and phillipsite and no other authigenic minerals. Facies $\mathrm{C}$ is a dark siltstone enriched in black vitric particles. Facies $\mathrm{C}$ contains very few smectites and no other authigenic mineral.

This sample shows a contact between homogenous tephra $(\mathrm{C})$ and volcaniclastic sediments affected by zeolitization (A, B). This small scale differential zeolitization points out the importance of fine scale detailed observations in this volcanosedimentary basin.

In the deeper part of the hole, all samples are zeolitized, except Sample 134-832B-59R-6, 120-122 cm, $710.71 \mathrm{mbsf}$, in Unit 5. This calcareous volcanic claystone (plagioclase, vitric) is characterized by few smectites and high biogenic calcite content (numerous foraminifers). The grain size of this interval is so small that extensive zeolitization does not occur. Generally, at both Sites 832 and 833 , we note that zeolitization is accentuated when grain size is coarse. Microbreccias are the preferential levels for zeolitization. Clayey levels do not contain abundant authigenic minerals. This observation shows that original porosity of the sediment is an important factor in controlling zeolitization.

\section{Authigenic Carbonates}

Calcite, dolomite, and magnesite occur in the deeper part of Hole 832. SEM observations show euhedral crystals of calcite. These euhedral calcite associated with dolomite and magnesite are typical of authi- 

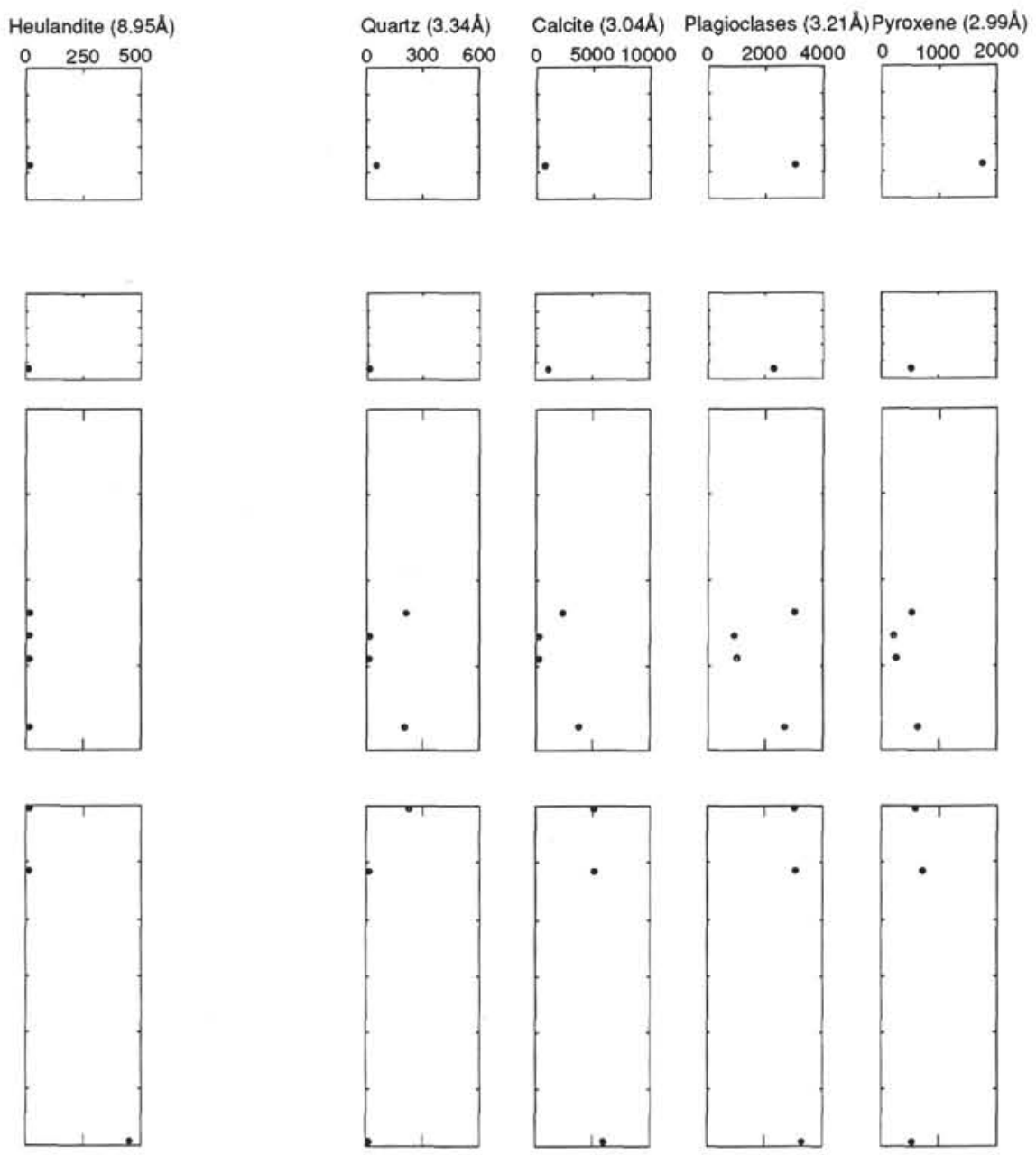

Figure 3 (continued).

genic formation. Magnesite occurrence is not very frequent (Table 1). Magnesite is present in Sample 134-832B-94R-2, 102-104 cm, 1041.52 mbsf, Unit 7, (with $\mathrm{MgO}=10.75 \%$ on bulk analysis), associated with dolomite and the zeolitic assemblage: phillipsite, analcime, chabazite, as shown XRD data (Fig. 8). This interval is characterized by the highest saponite content. Dolomite, in Sample 134-832B-78R-6, 122$124 \mathrm{~cm}, 893.65 \mathrm{mbsf}$, Unit 6, is associated with $\mathrm{Mg}$ zeolite (first occurrence of erionite in the hole). The presence of Mg-zeolite suggests that Unit 4 may have been affected by fluids more enriched in $\mathrm{Mg}$ than the fluids which interacted with overlying units

\section{Site 833}

Mineral occurrences vs. depth in the core, based on XRD analyses, are given in Table 5. Results of semi-quantitative micro-analyses for major components are related to lithostratigraphy in Figure 10.

\section{Primary Volcanic Minerals}

General mineralogical trends observed at Site 833 appear to be similar to Site 832. Pyroxene and plagioclases are anticorrelated with vitric components (Fig. 10). Pyroxene is ubiquitous from the top of the hole to Sample 134-832B-78R-1, 118-120 cm, $800.1 \mathrm{mbsf}$, Unit 4. Below, it is more sparsely distributed. Magnetite-titanomagnetite near the bottom of the hole (Pl. 3B) is nearly ubiquitous except in the deepest part of the hole. Amphibole is more abundant than in Site 832. Biotite occurs in Sample 134-833B-93R-2, 7-9 cm, $935.17 \mathrm{mbsf}$, not much altered. This sample is different from samples below and above,

which are rich in calcite and quartz: it displays a strong volcaniclastic trend with high content of plagioclase and pyroxene, low content of vitric fragments, smectites, and phillipsite. Quartz, sparsely distributed in the upper part of the hole is ubiquitous in the deeper part where the highest contents occur (Samples 134-833B-80R-4, 43-45 cm, 832.23 mbsf; 134-833B-81R-2, 18-20 cm, 829.68 mbsf; 134-833B94R-1, 138-140 cm, 944.68 mbsf; 134-833B-94R-2, 48-50 cm, 945.28 mbsf; Units 4 and 5; Fig. 10). In these levels, the quartz indicates an hydrothermal origin. SEM micromorphology shows overgrowths of euhedral quartz characteristic of authigenic formation.

\section{Detrital Components}

Near surface sediments (Samples 134-833A-2H-2, 46-48 cm, 11.46 mbsf; $134-833 \mathrm{~A}-3 \mathrm{H}-1,84-86 \mathrm{~cm}, 19.84 \mathrm{mbsf} ; 134-833 \mathrm{~A}-3 \mathrm{H}-$ 6, 75-77 cm, 27.25 mbsf; 134-833B-13R-1, 33-35 cm, $193.43 \mathrm{mbsf}$ ) show relatively low beidellite smectite abundance. These superficial weathered smectites (beidellite) that do not show authigenic texture and are aluminous compared to the smectites of the deeper sediments are attributed to Maewo detrital flux. Below the near surface interval, between 224 and 417 mbsf beidellite is no longer present (over 200 m; Fig. 10).

\section{Authigenic Minerals \\ Smectites}

First authigenic smectites occur in Sample 134-833B-39R-1, 23$25 \mathrm{~cm}, 443.43 \mathrm{mbsf}$, Unit 3 . Smectites and vitric are roughly anticor- 


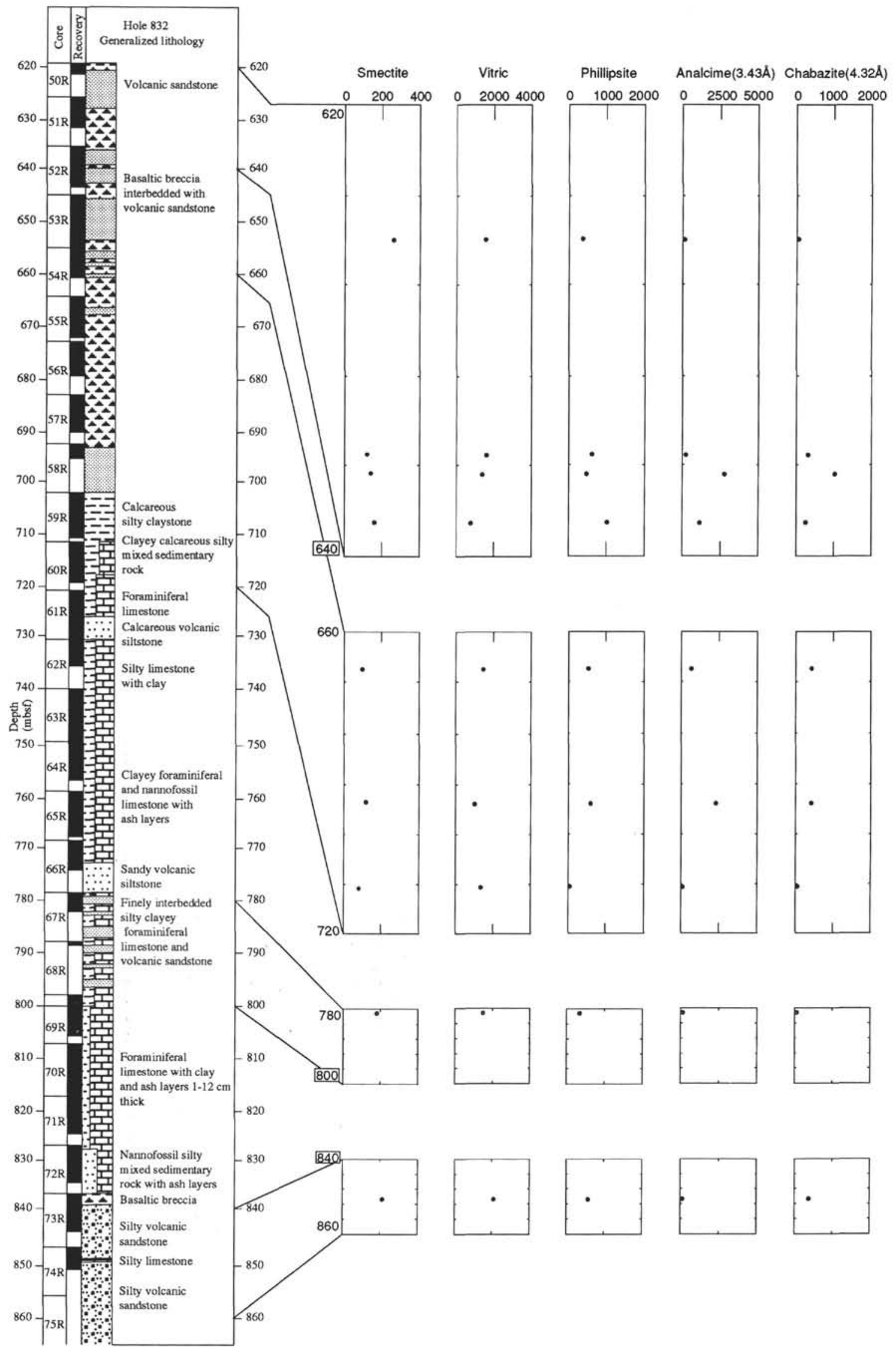

Figure 3 (continued). 
Thomsonite(6.55A) Heulandite(8.95A)
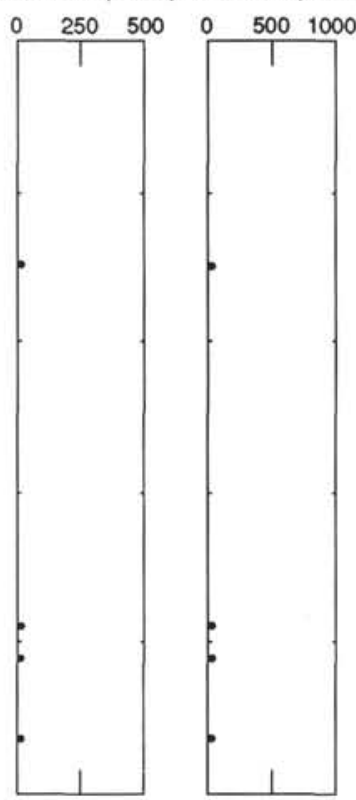

Quartz(3.34A)

025005000

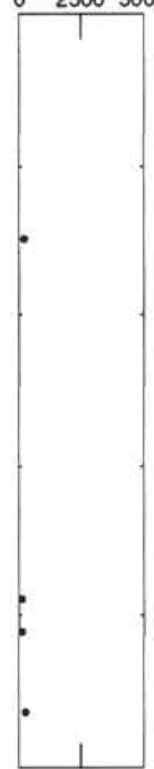

Calcite(3.04A) Plagioclases(3.21A) Pyroxene $(2.99 \AA)$

0500010000
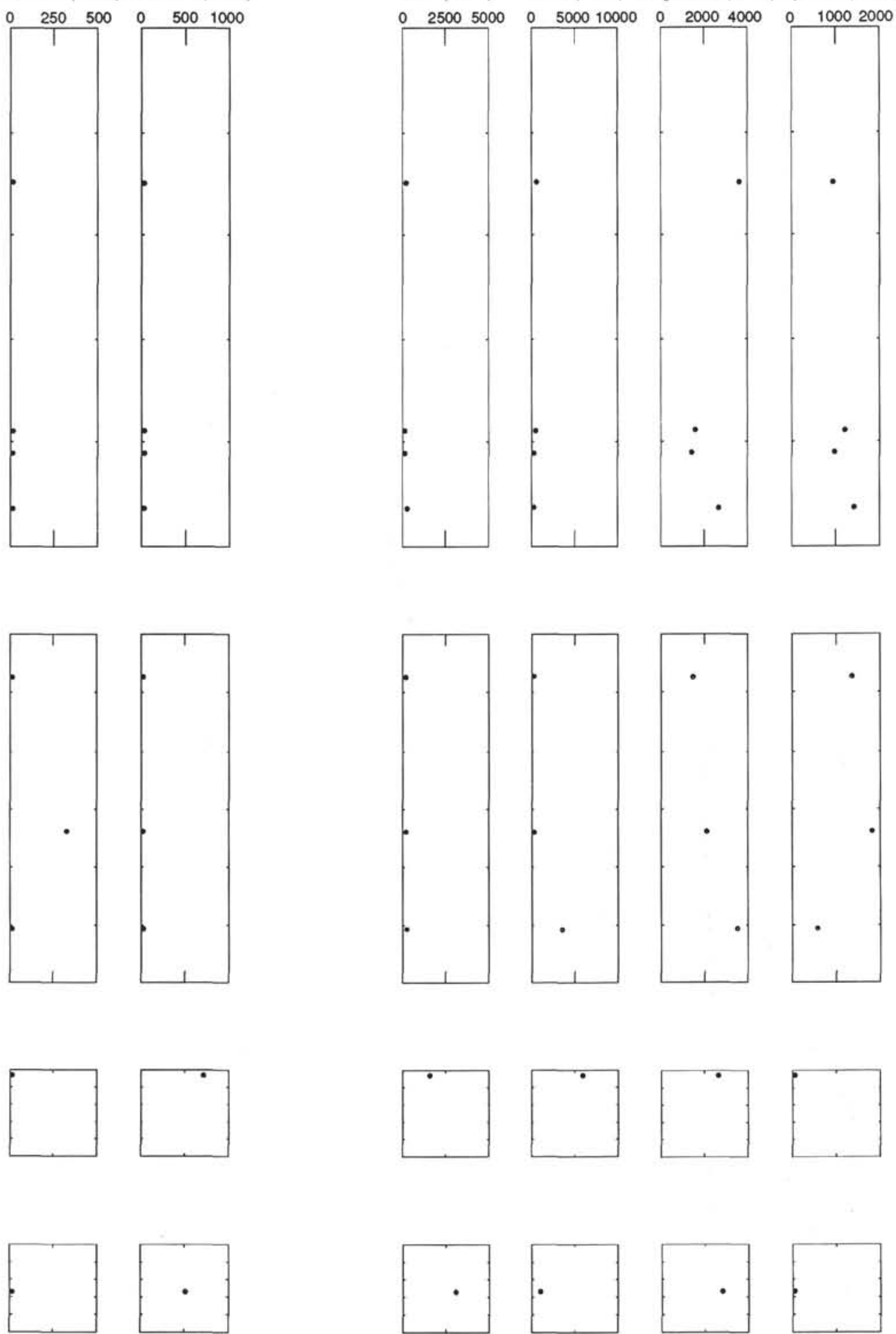

Figure 3 (continued).

related. Two gaps of smectites content occurs around 617-631 mbsf (between Samples 134-833B-59R-1, 70-72 cm, $617 \mathrm{mbsf}$, and 134833B-60R-4, 81-82 cm, 631.21 mbsf, and around $828 \mathrm{mbsf}$ : Samples 134-833B-81R-1, 14-16 cm, 828.14 mbsf; 134-833B-81R-1, 53-55 $\mathrm{cm}, 828.53 \mathrm{mbsf}$, Unit 4). These levels are also depleted in zeolites but are enriched in calcite, quartz, or volcanic components. These smectites are mostly nontronite and also saponite (but not so much than at Site 832). Globular or "en rosette" micromorphology of nontronite (Pl. 3A) is typical of authigenic and especially hydrothermal deposits (Hoffert et al., 1980).

\section{Minor Authigenic Minerals}

Gypsum, possible anhydrite (observed by SEM coupled with EDS microprobe analysis) and dolomite are these accessory phases. They 

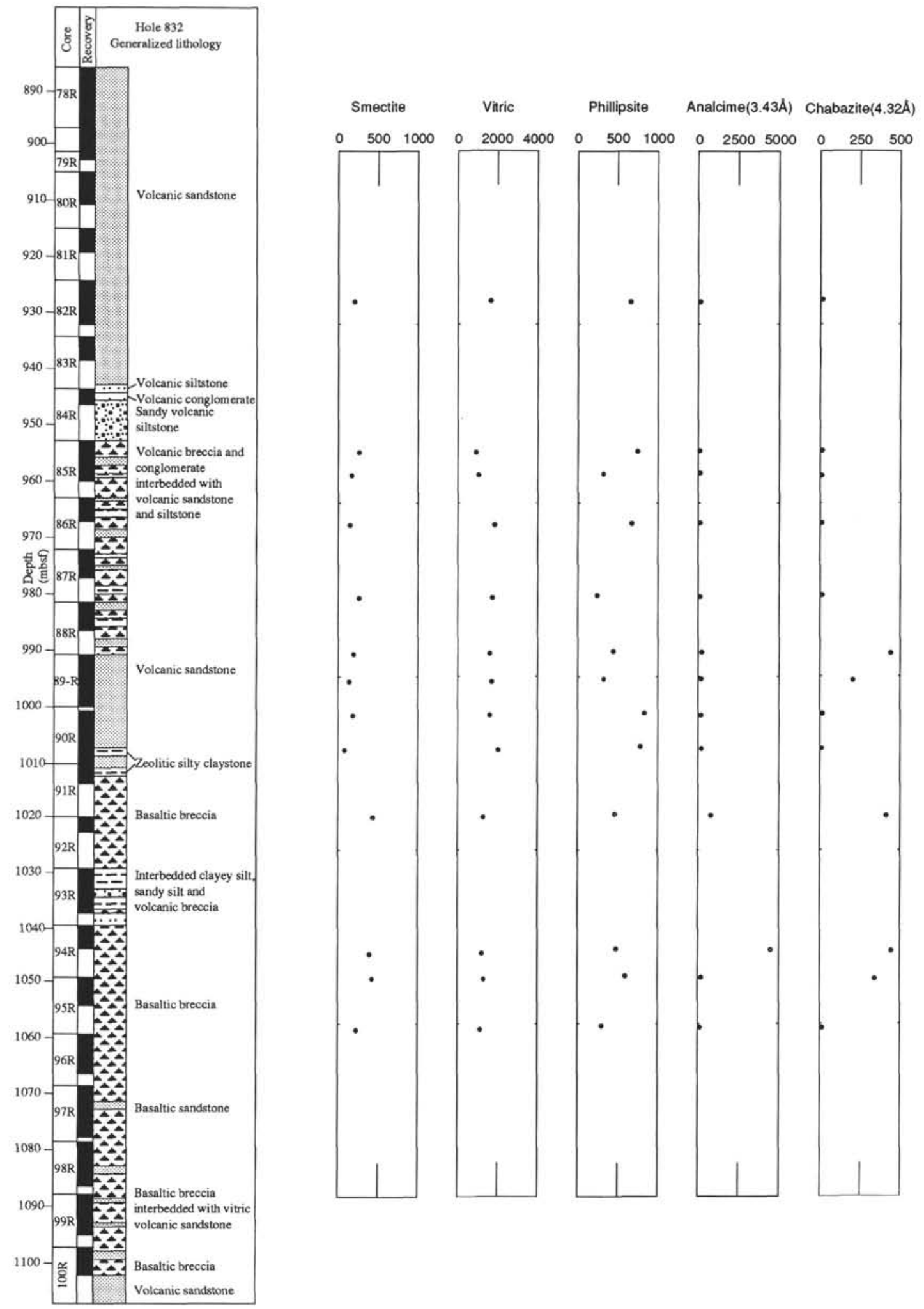

Figure 3 (continued). 


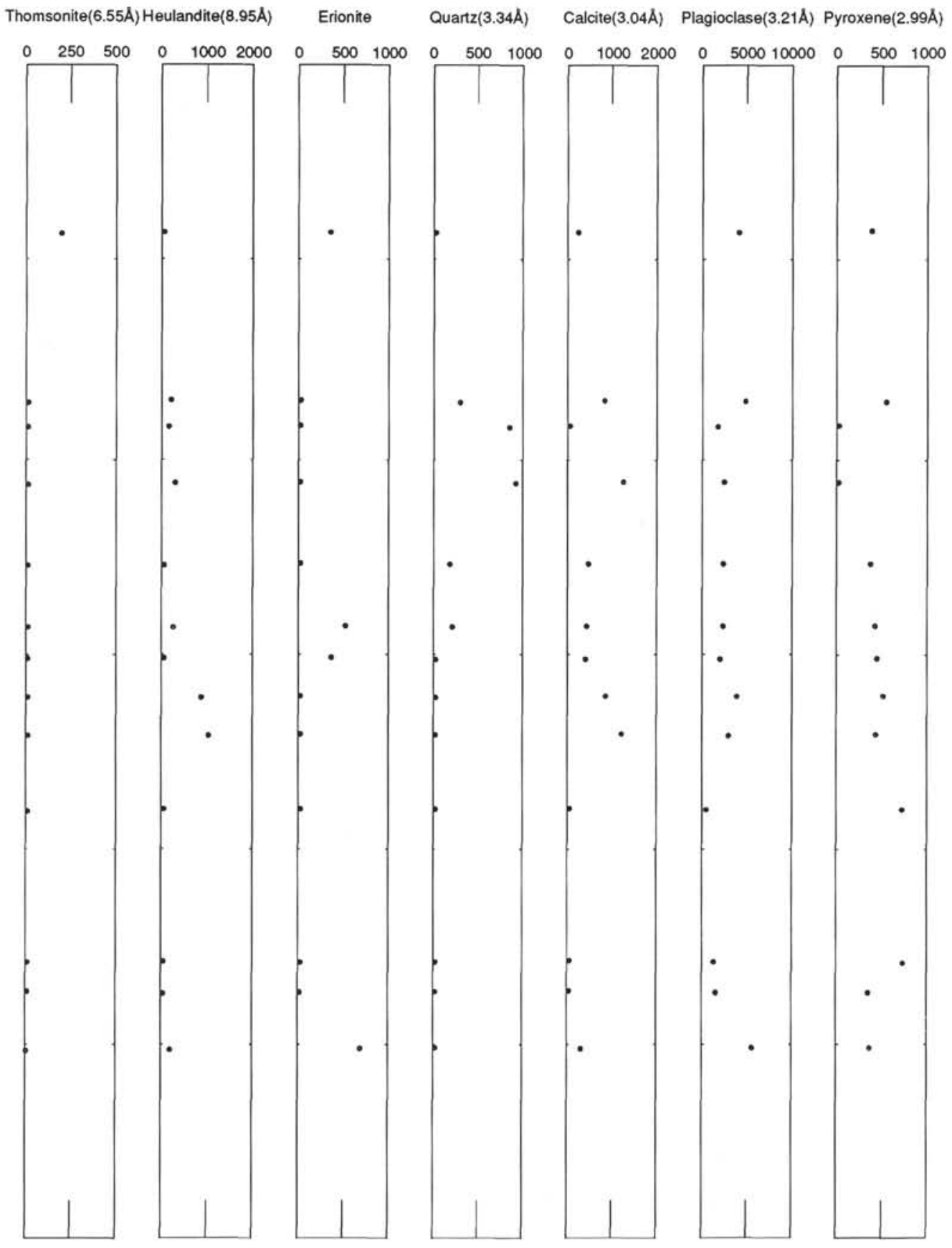

Figure 3 (continued).

are much less represented than in Site 832 and even are rare (Table 5 ). Euhedral gypsum is noticed. This occurrence of gypsum is similar to the interaction effect between hemipelagic sediment and a hydrothermal system studied by Al-Aasm and Blaise (1991).

\section{Zeolites}

Zeolite minerals similar to those found in Site 832 are also found in Site 833. However their distribution and assemblages are different and generally more complex (Tables 4 and 5).

Of 117 studied samples, 105 are zeolitized. Seventeen zeolite assemblages are present (Table 4). The most frequently observed assemblage is phillipsite plus analcime. Compared with Site 832, thomsonite is more common. On the contrary, erionite ( $\mathrm{Mg}$ phase) occurs just in two samples (134-833B-55R-1, 145-147 cm, 579.15 mbsf; 134-883B-55R-5, 65-67 cm, 584.35 mbsf; Unit 4). Analcime appears, but in low abundance and at shallower depths in the sediment column than phillipsite in Sample 134-833B-16R-2, 59-61 cm, 224.19 mbsf, Unit 2C. Analcime is not associated with any other zeolite or smectite. Sample 134-833B-24R-1, 75-77 cm, 299.25 mbsf, displays the first occurrence of phillipsite (also a single-mineral assemblage). Below this level, phillipsite and other zeolites are concurrently associated. Small gaps in phillipsite continuity appear at several levels, probably related to heterogeneities of the rock host: at $369.9 \mathrm{mbsf}, 416.41$ mbsf, 508-558 mbsf, at $566.08 \mathrm{mbsf}$, around $828 \mathrm{mbsf}$, and $936 \mathrm{mbsf}$ (Fig. 10). Analcime shows such small gaps, but more rarely. An important analcime gap occurs between Sample 134-833B-80R-4, 19-21 $\mathrm{cm}, 822.99$ mbsf, Unit 4, and Sample 134-833B-93R-2, 7-9 cm, 935.17 


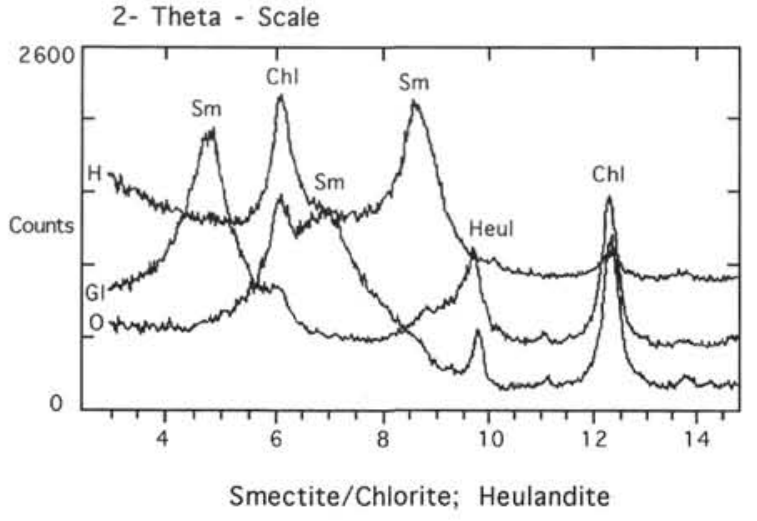

Figure 4. Chlorite ( $\mathrm{Chl})$ associated with smectites (Sm) on XRD data. The XRD spectra represent the treatments applied on clay fraction: orientated deposits (001 chlorite: $14.2 \AA$; 001 Na-smectites: $12.4 \AA$ ), glycerol (001 smectites: $17.8 \AA, 001$ chlorite: $14 \AA$ ), four hr $450^{\circ} \mathrm{C}$ - heating $(001$ smectites: $10 \AA$, 001 chlorite: $14 \AA$ ).

mbsf, Unit 5. These levels (devoid in pyroxene, amphibole, magnetite) contain phillipsite, smectites, and rare heulandite. Two samples exhibit an unusual assemblage: Sample 134-833B-81R-1, 14-16 cm, 828.14 mbsf, with no zeolite nor smectite occurrence, and Sample 134-833B-81R-1, 53-55 cm, 828.53 mbsf, with a single zeolite (heulandite). This analcime gap is localized above the sill intrusions in fine-grained deposits. First occurrence of chabazite is in Sample 134-833B-32R-1, 25-27 cm, 376.05 mbsf, Unit 3, associated with phillipsite and analcime. Distribution of chabazite is homogenous down to $617 \mathrm{mbsf}$ and scarce below this depth. The deepest occurrence of chabazite is in Sample 134-833B-79R-2, 103-105 cm, 811.23 mbsf, Unit 4. Zeolite-defined depth zones are accentuated by the assemblage chabazite plus thomsonite. First occurrence of thomsonite and heulandite is shown in the same sample: Sample 134-833B$39 \mathrm{R}-1,23-25 \mathrm{~cm}, 443.43 \mathrm{mbsf}$, Unit 3. But heulandite, which is scarcely distributed, occurs down to the bottom of the hole. As in Site 832 , coarse samples are the richest zeolites bearing levels.

One important difference between Sites 832 and 833 is the order of occurrence of zeolites, especially between phillipsite and analcime. XRD data show that analcime appears before phillipsite. This is confirmed by SEM micromorphological studies (Pl. 6), which show euhedral analcime surrounded by fibrous radiating phillipsite. This sequence excludes a diagenetic evolution from phillipsite to analcime (Iijima, 1978) and confirms an hydrothermal origin. $\mathrm{Na}^{+}$ions for this analcime are provided by the hydrothermal circulation of seawater. This analcime occurrence is comparable to the analcime of the Daito Ridge and Basin of the Philippine Sea, Sites 445 and 446 (Lee, 1988).

\section{GEOCHEMISTRY}

The bulk sediment geochemical composition of the North Aoba Basin volcaniclastic sediments reflects the major component inputs, including biogenic carbonates, volcaniclastic sediment related to source magma composition, and authigenically produced components. The relative importance of these components at various intervals in the sediment column may be recognized by examining the relative abundance of individual and combinations of major oxides, trace elements and REE patterns. The following section is aimed at using bulk sediment data to discern the relative importance of each of the major sedimentary components.

Tables 6, 7,8, and 9 show major, trace, and rare earth element results for analyses of the bulk materials. Table 10 shows the results of total carbon analyses and calculated $\mathrm{CO}_{2}$. Table 11 gives the calculated carbonate-free $\mathrm{CaO}$ content an the $\mathrm{Sr} / \mathrm{Ca}$ molar ratio. Elemental correlations are represented for each site and for the global sampling (Fig. 11).
Table 2. Microprobe chemical analysis of different types of vitric components.

\begin{tabular}{|c|c|c|c|c|}
\hline $\begin{array}{l}\text { Sample: } \\
\text { Interval: } \\
\text { Vitric component: }\end{array}$ & $\begin{array}{c}134-832 \mathrm{~A}-19 \mathrm{H}-1 \\
85-87 \mathrm{~cm} \\
\text { Glass shard }\end{array}$ & $\begin{array}{c}19 \mathrm{H}-1 \\
85-87 \mathrm{~cm} \\
\text { Pumice }\end{array}$ & $\begin{array}{c}18 \mathrm{H}-1 \\
32-34 \mathrm{~cm} \\
\text { Agglomerate }\end{array}$ & $\begin{array}{c}18 \mathrm{H}-1 \\
32-34 \mathrm{~cm} \\
\text { Glass shard }\end{array}$ \\
\hline Stochiometric elem & nental analysis (\%) & & & \\
\hline $\begin{array}{l}\mathrm{Si} \\
\mathrm{Ti} \\
\mathrm{Al} \\
\mathrm{Fe} \\
\mathrm{Ca} \\
\mathrm{Mg} \\
\mathrm{Mn} \\
\mathrm{Na} \\
\mathrm{K} \\
\mathrm{P} \\
\text { Total }\end{array}$ & $\begin{array}{r}29.85 \\
0.34 \\
8.36 \\
4.73 \\
3.07 \\
1.08 \\
0.1 \\
2.76 \\
1.92 \\
0.18 \\
52.39\end{array}$ & $\begin{array}{r}29.07 \\
0.63 \\
7.67 \\
6.36 \\
4.58 \\
1.21 \\
0.15 \\
1.33 \\
1.86 \\
0.17 \\
53.03\end{array}$ & $\begin{array}{r}28.22 \\
0.32 \\
8.59 \\
4.82 \\
4.81 \\
1.19 \\
0.15 \\
3.52 \\
1.84 \\
0.21 \\
53.67\end{array}$ & $\begin{array}{l}28.83 \\
0.34 \\
8.6 \\
4.56 \\
3.66 \\
1.42 \\
0 \\
3.54 \\
1.86 \\
0.19 \\
52.9\end{array}$ \\
\hline $\begin{array}{l}\mathrm{Wt} \% \\
\mathrm{SiO}_{2} \\
\mathrm{TiO}_{2} \\
\mathrm{Al}_{2} \mathrm{O}_{3} \\
\mathrm{Fe}_{2} \mathrm{O} \\
\mathrm{CaO} \\
\mathrm{MgO} \\
\mathrm{MnO} \\
\mathrm{Na}_{2} \mathrm{O} \\
\mathrm{K}_{2} \mathrm{O} \\
\mathrm{P}_{2} \mathrm{O}_{5}\end{array}$ & $\begin{array}{r}64.09 \\
0.57 \\
15.85 \\
6.79 \\
4.31 \\
1.8 \\
0.13 \\
3.73 \\
2.32 \\
0.41\end{array}$ & $\begin{array}{c}62.28 \\
1.05 \\
14.51 \\
9.11 \\
6.42 \\
2.01 \\
0.19 \\
1.8 \\
2.24 \\
0.39\end{array}$ & $\begin{array}{r}60.15 \\
0.53 \\
16.17 \\
6.87 \\
6.71 \\
1.97 \\
0.19 \\
4.72 \\
2.21 \\
0.48\end{array}$ & $\begin{array}{c}61.83 \\
0.57 \\
16.1 \\
6.54 \\
5.13 \\
2.36 \\
0 \\
4.78 \\
2.25 \\
0.44\end{array}$ \\
\hline
\end{tabular}

\section{Bulk Sediment Calcium Content}

Calcium is present in three major component, which are abundant in North Aoba Basin sediments: biogenic carbonate, Ca-bearing primary volcaniclastic components (glass shards, primary plagioclase, and pyroxenes), and authigenic components (Ca-zeolite minerals, authigenic calcite, and Ca-sulfate minerals, such as gypsum).

Bulk sediments influenced primarily by biogenic phases are chemically identified by their characteristically high concentration of bulk $\mathrm{CaO}$ and associated $\mathrm{Sr}$ (Hodkinson and Cronan, 1991) and much lower carbonate-free $\mathrm{CaO}$. For example, Sample 134-832B-40R-2, $23-25 \mathrm{~cm}$, contains 19.28 wt\% on bulk sample $\mathrm{CaO}(3443 \mathrm{mM} / \mathrm{kg}$ Ca) and $3.39 \mathrm{wt} \%$ carbonate free $\mathrm{CaO}$. This sample contains 715 $\mathrm{mg} / \mathrm{kg} \mathrm{Sr}(8.2 \mathrm{mM} / \mathrm{kg} \mathrm{Sr})$. Based on XRD analysis, this sample contains abundant calcite (Fig. 3), and a strong occurrence of biogenic calcite (foraminifers) based on SEM observations. Molar ratio $\mathrm{Sr} / \mathrm{Ca}$ in marine biogenic carbonate is about $16-20 \times 10^{-4}$ (Baker et al., 1982). The Sr/Ca ratio of Sample 832B-40R-2, 23-24 cm, shows the same order of value $2 \times 10^{-4}$.

Calcium and strontium measured in bulk sediments can also be attributed to primary volcanogenic phases. If volcanogenic components are the primary contributor of calcium, then bulk sediment $\mathrm{CaO}$ and carbonate-free $\mathrm{CaO}$ should be nearly the same values. For example, Sample 134-833A-3H-1, 82-84 cm, is composed of $10 \mathrm{wt} \%$ bulk sample $\mathrm{CaO}(1786 \mathrm{mM} / \mathrm{kg} \mathrm{Ca}), 9.36 \mathrm{wt} \%$ carbonate free $\mathrm{CaO}$, and 885 $\mathrm{mg} / \mathrm{kg} \mathrm{Sr}(10.10 \mathrm{mM} / \mathrm{kg} \mathrm{Sr})$. Based on petrographic observation and XRD analyses (Fig. 10), this sample contains plagioclase, pyroxene, vitric phase, with a trace of smectites and few calcite: essentially a volcaniclastic petrographic composition. The $\mathrm{Sr} / \mathrm{Ca}$ ratio is $57 \times 10^{-4}$.

Another example of very fresh ash (plagioclase and vitric phases) is Sample 134-832A-19H-1, 85-87 cm, with a low content of calcite. It contains $6.09 \mathrm{wt} \%$ of bulk sample $\mathrm{CaO}(1087 \mathrm{mM} / \mathrm{kg} \mathrm{Ca}), 3.65 \mathrm{wt} \%$ carbonate-free $\mathrm{CaO}$, and $420 \mathrm{mg} / \mathrm{kg} \mathrm{Sr}(4.8 \mathrm{mM} / \mathrm{kg} \mathrm{Sr})$. Some of the $\mathrm{Ca}$ is derived from biogenic calcite. The $\mathrm{Sr} / \mathrm{Ca}$ ratio is $44 \times 10^{-4}$. When the vitric ash is $\mathrm{Sr}$-enriched, the $\mathrm{Sr} / \mathrm{Ca}$ molar ratio is much higher (e.g., Sample $134-832 \mathrm{~A}-2 \mathrm{H}-2,6-7 \mathrm{~cm}, \mathrm{Sr} / \mathrm{Ca}$ ratio is $87 \times 10^{-4}$ ).

Calcium and strontium measured in bulk sediments may also be derived from authigenic components, such as the zeolite minerals. For example, Sample 134-833B-71R-1, 64-66 cm, contains $1612 \mathrm{mg} / \mathrm{kg}$ $\mathrm{Sr}(18.4 \mathrm{mM} / \mathrm{kg} \mathrm{Sr})$, one of the highest concentration of $\mathrm{Sr}$ in Site 833 (Table 3$)$. This sample contains 9.85 wt \% bulk sediment $\mathrm{CaO}(1755$ $\mathrm{mM} / \mathrm{kg} \mathrm{Ca}$ ) and $7.90 \%$ carbonate-free $\mathrm{CaO}$. The small change in $\mathrm{CaO}$ 
Table 3. Bibliographic characteristics of the major zeolites, Sites 832 and 833 (from Gottardi and Galli, 1985).

\begin{tabular}{|c|c|c|c|c|}
\hline Name & Formula & $\begin{array}{c}\text { Extra framework } \\
\text { cations }\end{array}$ & Occurrence & Synthesis \\
\hline $\begin{array}{l}\text { Thomsonite } \\
\text { fibrous zeolite }\end{array}$ & $\mathrm{Na}_{4} \mathrm{Ca}_{8}\left(\mathrm{Al}_{20} \mathrm{Si}_{20} \mathrm{O}_{80}\right) \cdot 24 \mathrm{H}_{2} \mathrm{O}$ & $\mathrm{Sr}, \mathrm{K}, \mathrm{Mg}, \mathrm{Ba}, \mathrm{Fe}$ & $\begin{array}{l}\text { Hydrothermal, even that associated with } \\
\text { deep sea basalts (Bass et al., 1973) } \\
\text { Sedimentary genesis, as cement of } \\
\text { palagonite tuffs (Hay, Iijima, 1968) }\end{array}$ & $\begin{array}{l}\text { Barrer, Denny } \\
\text { (1961) } \\
\text { Wirsching (1981) } \\
150^{\circ}-250^{\circ} \mathrm{C}\end{array}$ \\
\hline $\begin{array}{l}\text { Analcime } \\
\text { zeolite with singly } \\
\text { connected 4-ring } \\
\text { chains }\end{array}$ & $\mathrm{Na}_{16}\left(\mathrm{Al}_{16} \mathrm{Si}_{32} \mathrm{O}_{96}\right) \cdot 16 \mathrm{H}_{2} \mathrm{O}$ & $\mathrm{Ca}, \mathrm{K}, \mathrm{Mg}, \mathrm{Fe}$ & $\begin{array}{l}\text { Wide spectrum of genetic type: from } \\
\text { sedimentary, to metamorphic of low grade, to } \\
\text { magmatic or hydrothermal }\end{array}$ & $\begin{array}{l}\text { Franco, Aiello (1968) } \\
\text { Abe, Aoki (1976) } \\
\text { Höller, Wirsching (1978) } \\
100^{\circ}-300^{\circ} \mathrm{C}\end{array}$ \\
\hline $\begin{array}{l}\text { Phillipsite } \\
\text { zeolite with doubly } \\
\text { connected 4-rings } \\
\text { chains }\end{array}$ & $\mathrm{K}_{2}\left(\mathrm{Ca}_{0.5} \mathrm{Na}\right)_{4}\left(\mathrm{Al}_{6} \mathrm{Si}_{10} \mathrm{O}_{32}\right) \cdot 12 \mathrm{H}_{2} \mathrm{O}$ & $\begin{array}{l}\mathrm{Ba}, \mathrm{Sr}, \mathrm{Mg}, \mathrm{Fe} \\
\text { Absent in } \\
\text { deep-sea } \\
\text { phillipsite }\end{array}$ & $\begin{array}{l}\text { Common mineral in segiments and vugs of massive } \\
\text { rocks, frequent in deep sea sediments and vitric tuffs: } \\
\text { formation of phillipsite is possible at ambient } \\
\text { temperature; hydrothermal temperature range is wide: } \\
\text { from } 60^{\circ} \mathrm{C} \text { to } 200^{\circ} \mathrm{C}\end{array}$ & $\begin{array}{l}\text { Sersale et al. (1965) } \\
250^{\circ} \mathrm{C} \\
\text { Collela, Aiello (1975) } \\
80^{\circ} \mathrm{C}\end{array}$ \\
\hline $\begin{array}{l}\text { Chabazite } \\
\text { zeolite with } 6 \text { rings }\end{array}$ & $\mathrm{Ca}_{2}\left(\mathrm{Al}_{4} \mathrm{Si}_{8} \mathrm{O}_{24}\right) \cdot 12 \mathrm{H}_{2} \mathrm{O}$ & $\mathrm{Na}, \mathrm{K}, \mathrm{Sr}, \mathrm{Mg}, \mathrm{Ba}, \mathrm{Fe}$ & $\begin{array}{l}\text { Sedimentary genesis (alteration of glass } \\
\text { bearing tuffs is common); hydrothermal origin } \\
\text { (associated with basalts, Bass et al., 1973) }\end{array}$ & $\begin{array}{l}\text { Barrer, Baynham(1956) } \\
\text { Ailo, Franco (1968) } \\
60^{\circ}-100^{\circ} \mathrm{C}\end{array}$ \\
\hline $\begin{array}{l}\text { Erionite } \\
\text { zeolite with } 6 \text { rings }\end{array}$ & $\mathrm{NaK}_{2} \mathrm{MgCa}_{1.5}\left(\mathrm{Al}_{8} \mathrm{Si}_{28} \mathrm{O}_{72}\right) \cdot 28 \mathrm{H}_{2} \mathrm{O}$ & $\mathrm{Fe}$ & Sedimentary genesis; Hydrothermal origin & Nikilina et al. (1981) \\
\hline $\begin{array}{l}\text { Heulandite } \\
\text { zeolite of } \\
\text { heulandite group }\end{array}$ & $\begin{array}{l}(\mathrm{Na}, \mathrm{K}) \mathrm{Ca}_{4}\left(\mathrm{AlgSi}{ }_{27} \mathrm{O}_{72}\right) \cdot 24 \mathrm{H}_{2} \mathrm{O} \\
\text { Continuous solid solution series } \\
\text { with clinoptilotite }\end{array}$ & $\mathrm{Sr}, \mathrm{Mg}, \mathrm{Ba}$ & $\begin{array}{l}\text { From shallow to moderate depth, up to the first } \\
\text { zone of very low metamorphism (analcime- } \\
\text { heulanite metamorphic facies of Coombs et } \\
\text { al., (1959); or the highest diagentic zone of } \\
\text { Utada, 1970): most common occurrence in veins and } \\
\text { geodes of hydrothermal origin }\end{array}$ & $\begin{array}{l}\text { Ames (1963) } \\
250^{\circ}-300^{\circ} \mathrm{C}\end{array}$ \\
\hline
\end{tabular}
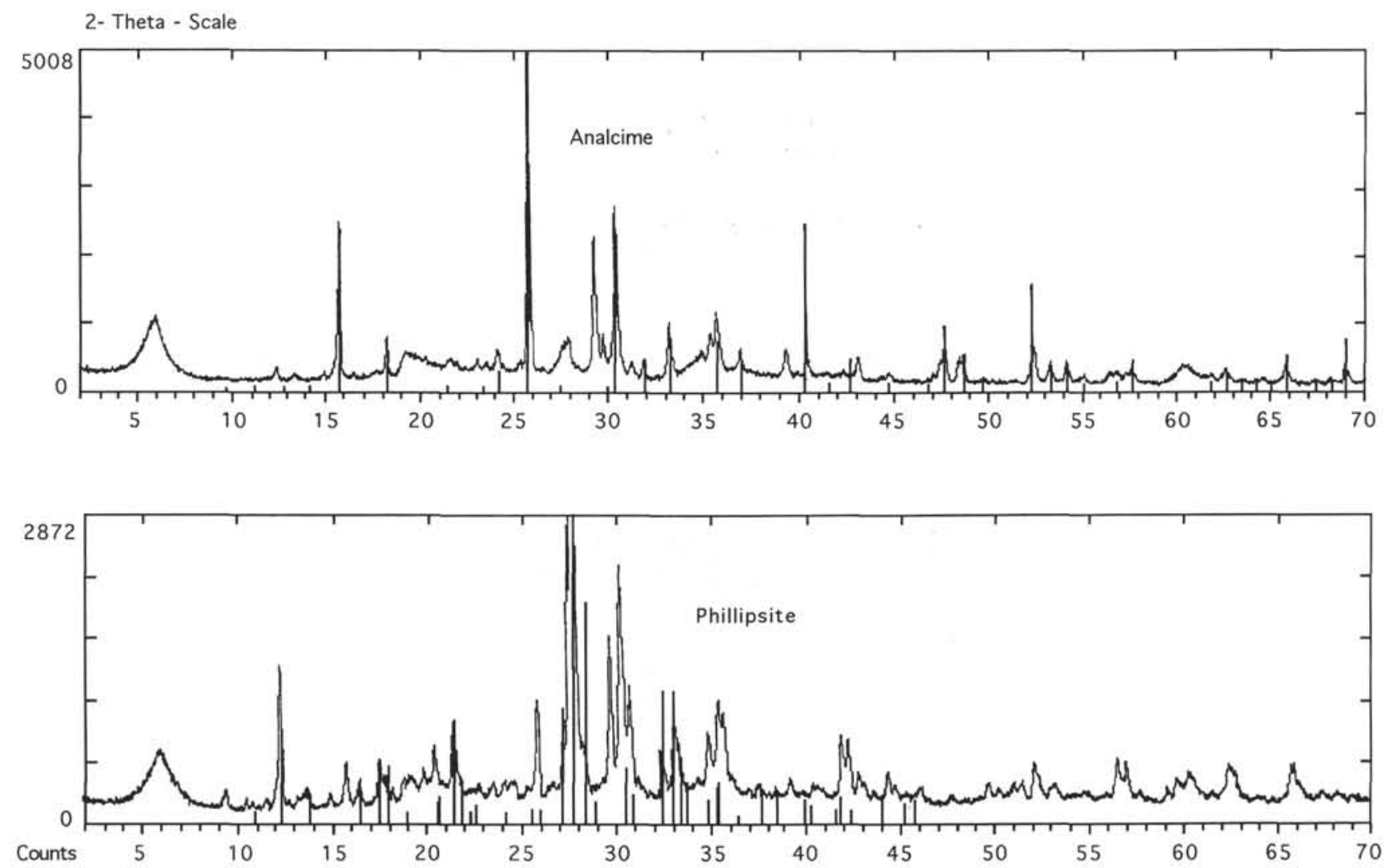

Figure 5. Phillipsite (Sample 134-833B-66R-4, 41-43 cm), analcime (Sample 134-833B-53R-4, 21-23 cm) XRD spectra. Markers of the JCPDS reference, quoted at the bottom of the figures, are superimposed on the spectra. 

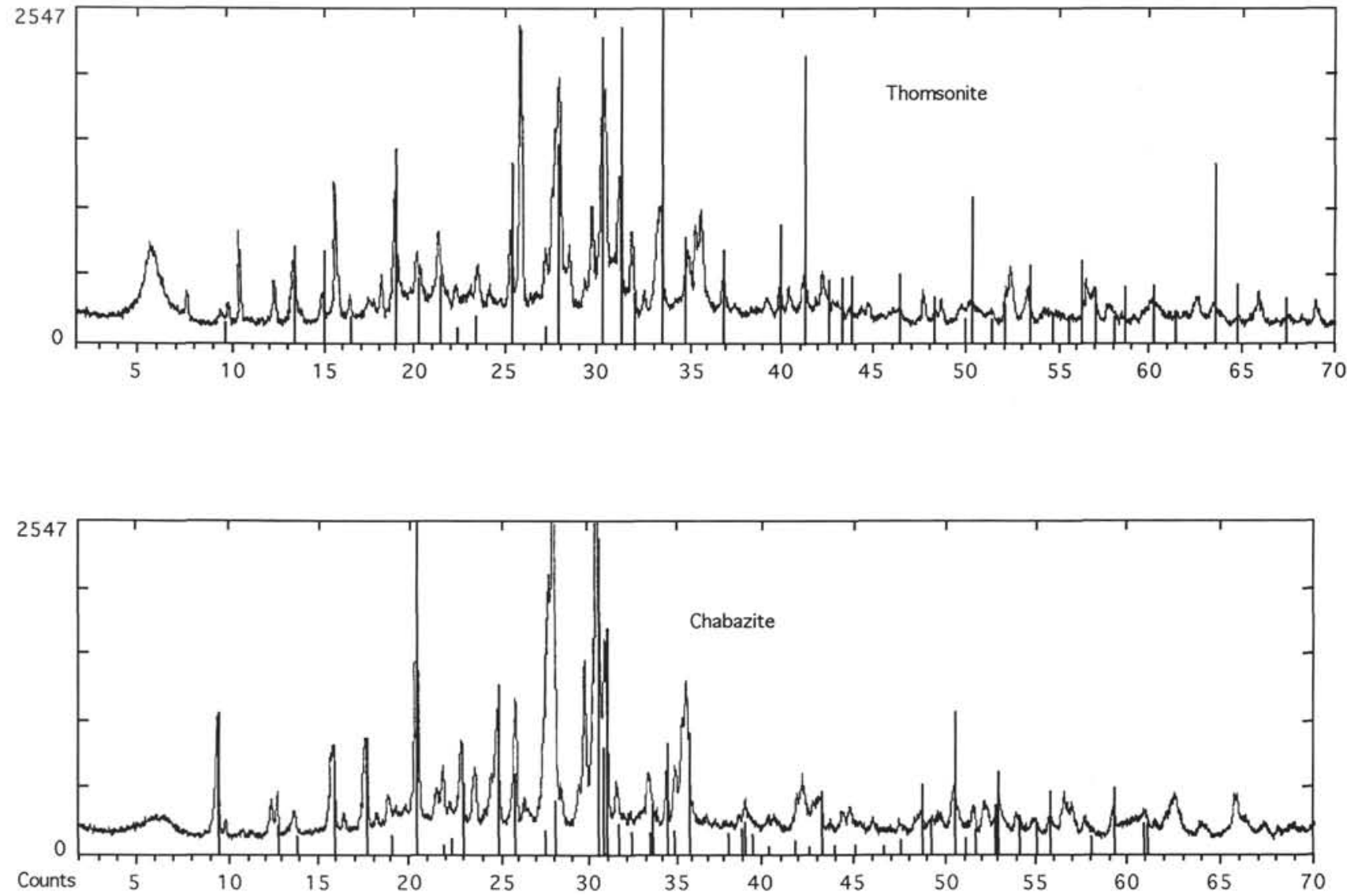

Figure 6. Chabazite (Sample 134-833B-53R-1, 89-91 cm), thomsonite (Sample 134-833B-54R-5, 55-57 cm) XRD spectra. Markers of the JCPDS reference, quoted at the bottom of the figures, are superimposed on the spectra.

Table 4. Zeolites assemblages with their frequencies, Sites 832 and 833.

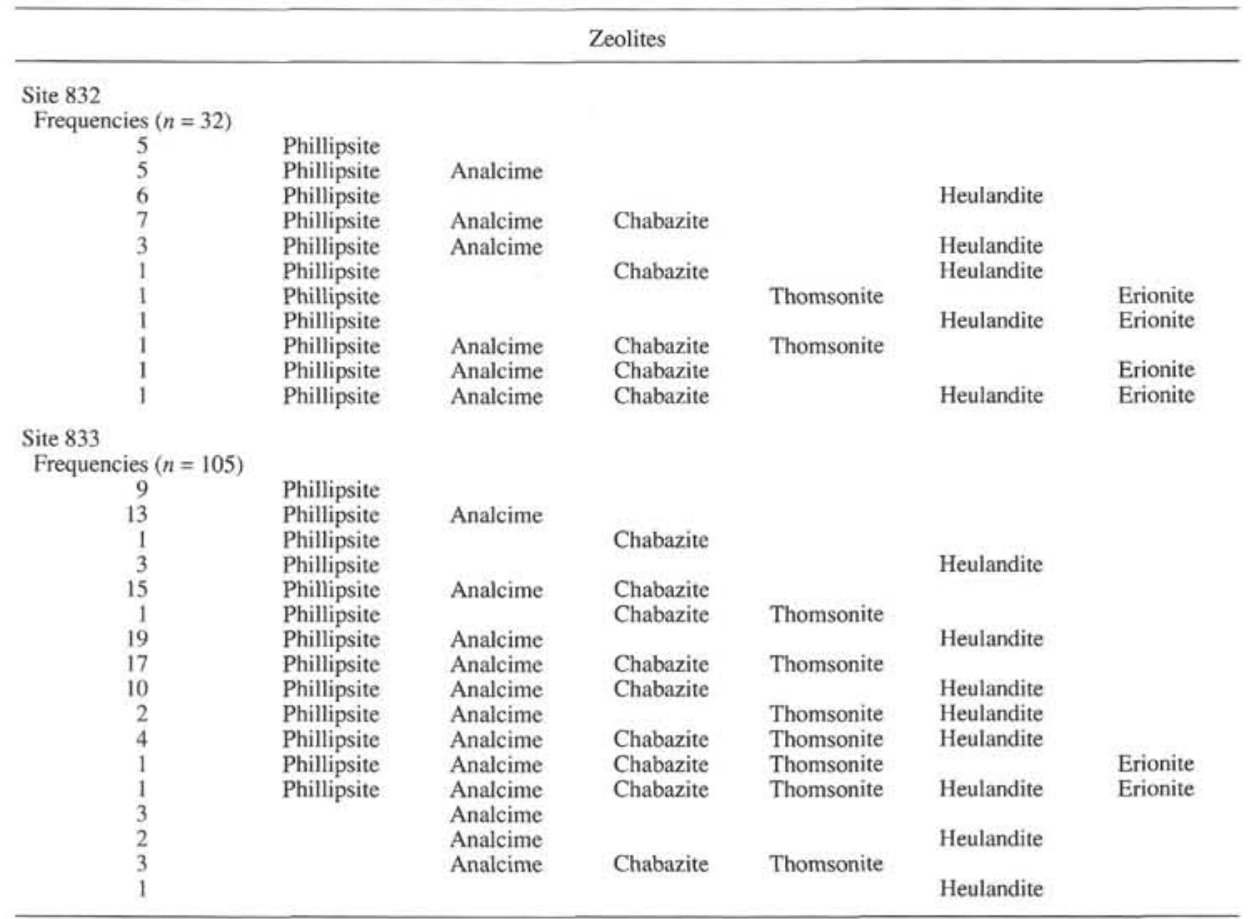



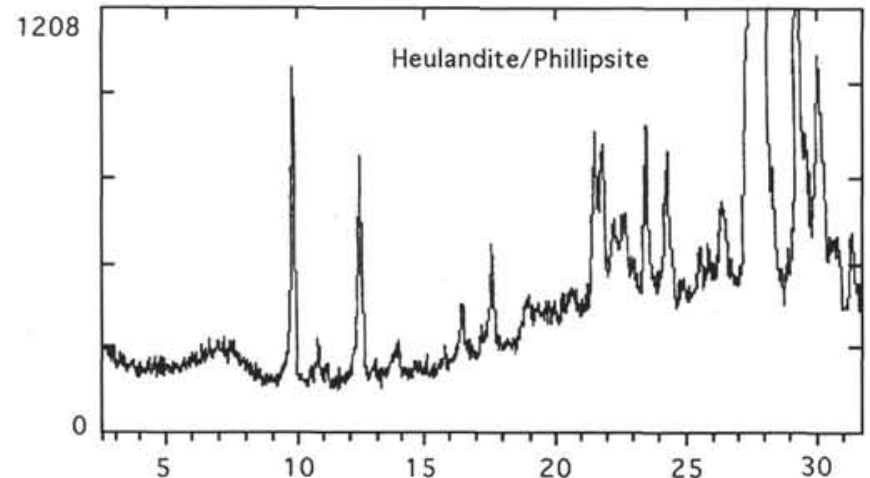
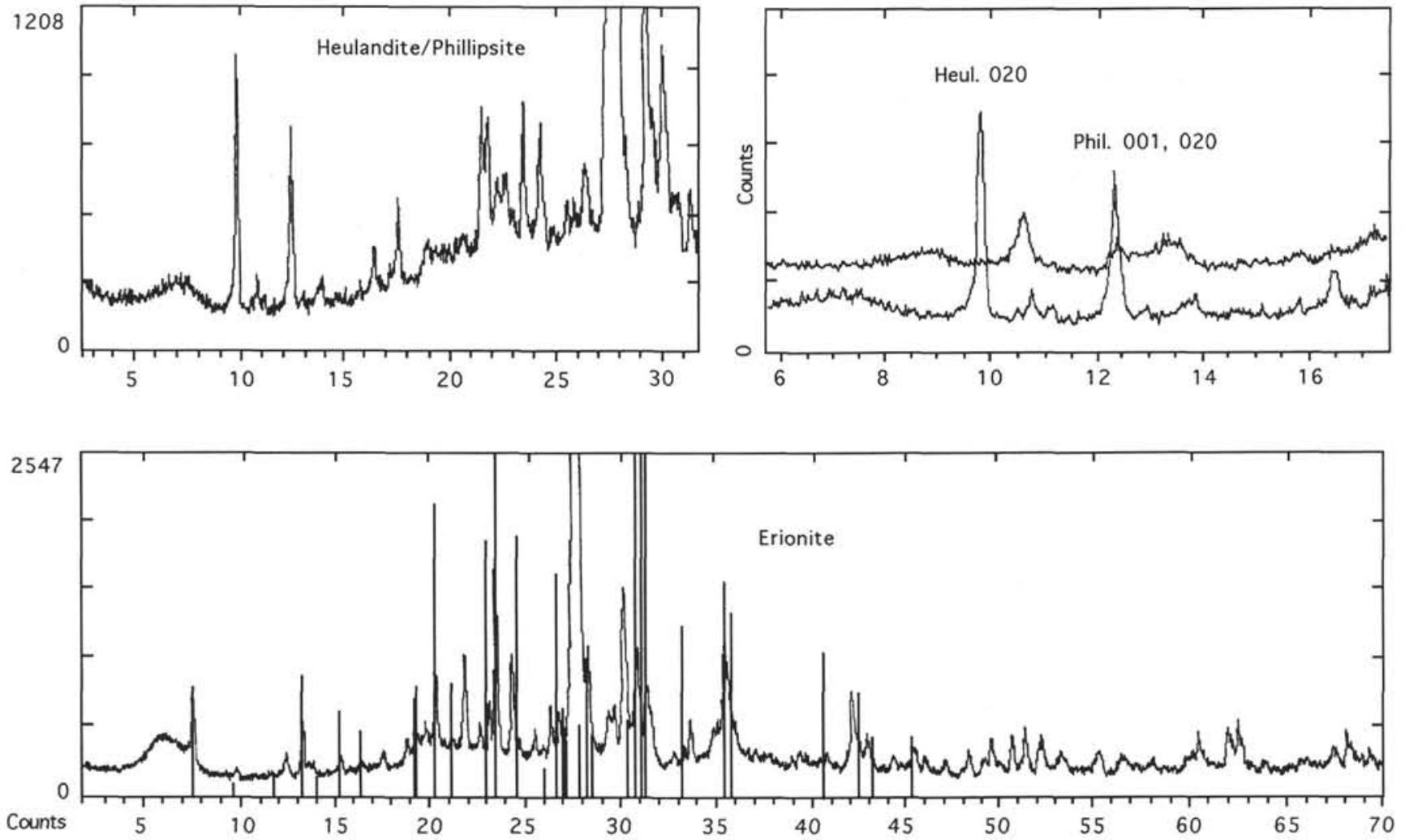

Figure 7. Erionite (Sample 134-832B-100R-4, 42-44 cm) XRD spectra. Differentiation clinoptilolite/heulandite with the Mumpton test (overnight heating at $450^{\circ} \mathrm{C}$ ): heulandite is destroyed by heat. Heated sample spectra overlies the original heulandite spectra (Sample 134-832B-92R-2, 52-54 cm); note the disappearance of the heulandite peak. Heulandite is associated with phillipsite. Markers of the JCPDS reference, quoted at the bottom of the figures, are superimposed on the spectra.

from bulk to carbonate-free $\mathrm{CaO}$ indicates that carbonate-derived $\mathrm{Ca}$ is relatively low. Based on XRD analyses, the most abundant minerals are the zeolite minerals (phillipsite, chabazite, and thomsonite). The other mineral occurrences are plagioclase, pyroxene, and very rare calcite. Based on petrographic observation, plagioclases and pyroxene primary phases are not abundant. The $\mathrm{Sr} / \mathrm{Ca}$ ratio is $105 \times 10^{-4}$. This sample contains less $\mathrm{Ca}$ or more $\mathrm{Sr}$ than is expected in biogenic or volcaniclastic phases. Some of the $\mathrm{Ca}$ must be derived from authigenic components, such as chabazite (Sample 134-832B-94R-2, $102-104 \mathrm{~cm})$. But the strong content of $\mathrm{Sr}$ marks also the authigenic phases. The $\mathrm{Sr} / \mathrm{Ca}$ ratios are very variable in the deeper part of Site 833 , with a 10 factor (Table 11). This part of the hole is affected by interstitial solutions mobilized by sill intrusions.

The ternary plot $\mathrm{MgO}-\mathrm{CaO}-\mathrm{CO}_{2}$ (Fig. 12) is used to group samples based on bulk sediment chemical composition. These groupings illustrate relative importance of calcite, dolomite, magnesite, and $\mathrm{Ca}$ - and $\mathrm{Mg}$-bearing non-carbonate phases contained in individual samples. Determination of biogenic carbonate and authigenic carbonate is not definitive using this type of diagram. However, coupled with petrographic observation, mineralogical data from XRD analyses, and textural evidence derived from SEM analyses, such differentiation can be made.

$\mathrm{CaO}$ and $\mathrm{MgO}$ are from bulk chemical analyses. $\mathrm{CO}_{2}$ for this plot (Fig. 12) is based on total carbon analyses. For reference, stoichiometric calcite (closed diamond), stoichiometric dolomite (closed triangle), and stoichiometric magnesite (closed square) are shown on the diagram. The open symbols are data for Sites 832 and 833. Numbers on the diagram refer to samples shown in Tables 6 and 7. Three general groups are indicated by sample clusters in this plot coupled with petrographic, XRD, and SEM observations. We try to differentiate between samples influenced by primarily authigenic carbonate (dolomite, magnesite, and inorganic calcite), biogenic carbonate (calcite only) or $\mathrm{Ca}$ - and $\mathrm{Mg}$-bearing non-carbonate phases. In the paragraph below, numbers with a star refer to samples of Site 832 .

1. Samples dominated by magnesite plus dolomite, where $\mathrm{Ca}$ and $\mathrm{Mg}$ reside primarily in authigenic phases. The most obvious examples of Group I are Samples 26 (134-833B-78R-4, 27-29 cm, 803.77 mbsf) and $16^{*}(134-832 B-94 \mathrm{R}-2,102-104 \mathrm{~cm}, 1041.52 \mathrm{mbsf})$.

2. Samples dominated by calcite plus dolomite, where Ca resides primarily in biogenic phases. Group II is the cluster, which includes samples $3^{*}, 4^{*}, 5^{*}, 6^{*}, 13^{*}$, and $2,17,24,28,29,30$. A subgroup may be represent with Samples 24, 28, 29, and 30 where $\mathrm{Ca}$ (and Mg) resides also in authigenic phases: euhedral calcite and dolomite observed on SEM data. Notice that these samples are located in the deeper part of Site 833.

3. Samples with little or no carbonate minerals, where $\mathrm{Ca}$ and $\mathrm{Mg}$ reside primarily in non-carbonate phases. Group III is the cluster that includes Samples $7^{*}, 8^{*}, 9^{*}, 10^{*}, 11^{*}, 12^{*}, 14^{*}, 17^{*}, 18^{*}$, and $5,6,7,8$, $9,10,11,14,16,21$, and 23 .

An intermediate area is located between the clusters of Groups II and III. This area (gray color in the plot) includes samples of mixed components (biogenic carbonates, volcaniclastic, and authigenic noncarbonate phases). These samples are affected by the dilutive effect of carbonates.

Based on SEM micromorphological data, the carbonates are biogenic (foraminifers) in the upper part of the drills. In the deeper part, authigenic carbonate phases appears (Pls. 2 and 3). In the bottom of the Hole $832, \mathrm{Mg}$ carbonates (dolomite, magnesite) affect the altered 
Table 5. Mineralogical occurrence and distribution, Holes 833A and 833B.

\begin{tabular}{|c|c|c|c|c|c|c|c|c|c|c|c|c|c|c|c|c|c|}
\hline Unit & Sample $(\mathrm{cm})$ & $\begin{array}{l}\text { Depth } \\
\text { (mbsf) }\end{array}$ & Phillipsite & Analcime & Chabazite & Thomsonite & Heulandite & Erionite & Smectite & Halite & Quartz & Calcite & $\begin{array}{c}\text { Rare } \\
\text { occurrence }\end{array}$ & Plagioclase & Pyroxene & Amphibole & Magnetite \\
\hline
\end{tabular}

$\begin{array}{lcl} & 134-833 \mathrm{~A}- & \\ \text { 1A } & 2 \mathrm{H}-2,46-48 & 11.46 \\ \text { 1A } & 3 \mathrm{H}-1.84-6 & 19.84 \\ \text { 1A } & 3 \mathrm{H}-6,75-77 & 27.25 \\ \text { 1A } & 5 \mathrm{H}-2,24-26 & 34.34 \\ \text { 1B } & 7 \mathrm{H}-4.24-26 & 49.94 \\ \text { 1B } & 7 \mathrm{H}-5,63-65 & 51.83\end{array}$

$2 \mathrm{~B} \quad \begin{aligned} & 134-833 \mathrm{~B}- \\ & 12 \mathrm{R}-2,83-85\end{aligned}$

$2 \mathrm{~B} \quad \begin{aligned} & 134-833 \mathrm{~A}- \\ & 26 \mathrm{X}-2,23-25\end{aligned}$

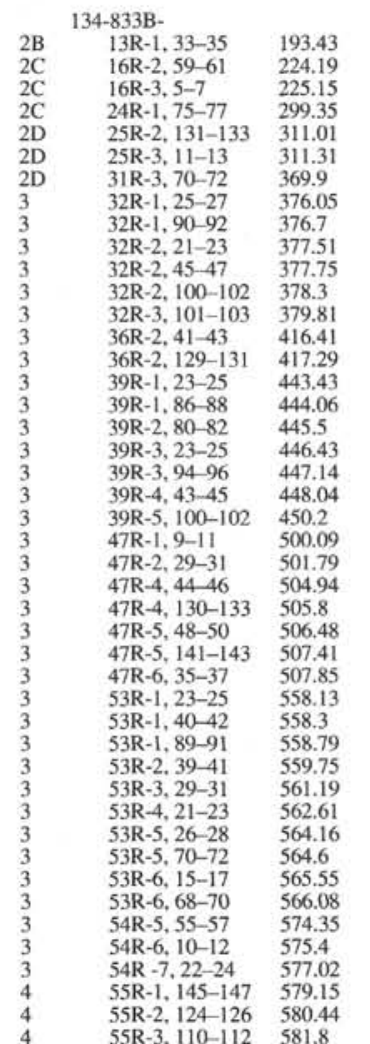


Table 5 (continued).

\begin{tabular}{|c|c|c|c|c|c|c|c|c|c|c|c|c|c|c|c|c|c|}
\hline Unit & Sample $(\mathrm{cm})$ & $\begin{array}{l}\text { Depth } \\
\text { (mbsf) }\end{array}$ & Phillipsite & Analcime & Chabazite & Thomsonite & Heulandite & Erionite & Smectite & Halite & Quartz & Calcite & $\begin{array}{c}\text { Rare } \\
\text { occurrence }\end{array}$ & Plagioclase & Pyroxene & Amphibole & Magnetite \\
\hline 4 & 55R-5, 65-67 & 584.35 & + & + & + & + & & + & + & & + & + & & + & + & & + \\
\hline 4 & 55R-6, $113-115$ & 586.33 & + & 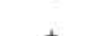 & + & + & t & & + & & & + & & + & + & & + \\
\hline${ }_{4}^{4}$ & $\begin{array}{l}59 R-1,70-72 \\
59-5,36-38\end{array}$ & $\begin{array}{l}617 \\
62266\end{array}$ & 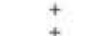 & + & + & & $\stackrel{+}{+}$ & & & & 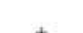 & + & & + & + & t & + \\
\hline $\begin{array}{l}4 \\
4\end{array}$ & $\begin{array}{l}59 R-5,36-38 \\
59-5,112-114\end{array}$ & $\begin{array}{l}622.66 \\
623.42\end{array}$ & $\begin{array}{lll}+ \\
+\end{array}$ & & + & & + & & & & \pm & + & & + & + & + & \pm \\
\hline $\begin{array}{l}4 \\
4\end{array}$ & $\begin{array}{l}59 R-5,112-114 \\
60 R-3,126-128\end{array}$ & $\begin{array}{l}623.42 \\
630.16\end{array}$ & $\begin{array}{l}+ \\
+\end{array}$ & & & & & & & & $\begin{array}{llll}+ \\
+\end{array}$ & $\begin{array}{llll}+ \\
+\end{array}$ & & $\begin{array}{lll}+ \\
+\end{array}$ & $\begin{array}{lll}+ \\
+\end{array}$ & + & $\begin{array}{l}+ \\
+\end{array}$ \\
\hline 4 & $60 \mathrm{R}-4,81-83$ & 631.21 & + & + & & & + & & & & + & + & & + & + & & + \\
\hline 4 & $65 \mathrm{R}-1,60-62$ & 674.8 & + & + & & & + & & + & & + & + & & + & + & & + \\
\hline 4 & $65 \mathrm{R}-1,138-140$ & 675.58 & + & + & + & & + & & + & & + & + & & + & + & + & + \\
\hline 4 & $65 R-2,62-64$ & 676.32 & + & + & & & + & & + & & & + & & + & + & & + \\
\hline 4 & $65 \mathrm{R}-3,23-25$ & 677.43 & + & + & & & + & & + & & + & + & & + & + & + & + \\
\hline 4 & $65 \mathrm{R}-3,83-85$ & 678.03 & + & + & & & + & & + & & + & + & & + & + & + & + \\
\hline 4 & $65 \mathrm{R}-4,44-46$ & 679.14 & + & + & & & + & & + & & & + & & + & + & + & + \\
\hline 4 & $65 R-4,134-136$ & 680.04 & + & + & & & + & & + & & + & + & & + & + & + & + \\
\hline 4 & $\begin{array}{l}65 \mathrm{R}-5,38-40 \\
65 \mathrm{P}-56-88\end{array}$ & 680.58 & + & + & & & + & & + & & + & + & & + & + & & + \\
\hline 4 & $\begin{array}{l}65 \mathrm{R}-5,86-88 \\
65 \mathrm{R}-61-23\end{array}$ & $\begin{array}{l}681.06 \\
681.91\end{array}$ & + & + & & + & + & & + & & + & + & & + & + & + & + \\
\hline 4 & $\begin{array}{l}65 \mathrm{R}-6,21-23 \\
65 \mathrm{R}-6\end{array}$ & $\begin{array}{l}681.91 \\
68271\end{array}$ & + & + & & & \pm & & + & & + & + & & + & + & & + \\
\hline $\begin{array}{l}4 \\
4\end{array}$ & $\begin{array}{l}65 \mathrm{R}-6,101-103 \\
66-1,143-145\end{array}$ & $\begin{array}{l}682.71 \\
685.23\end{array}$ & $\begin{array}{lll}+ \\
+\end{array}$ & $\stackrel{+}{+}$ & + & & + & & $\begin{array}{lll}+ \\
+\end{array}$ & & + & + & & $\begin{array}{l}+ \\
\pm\end{array}$ & \pm & & $\stackrel{+}{+}$ \\
\hline $\begin{array}{l}4 \\
4\end{array}$ & $\begin{array}{l}66 \mathrm{R}-1,143-145 \\
66 \mathrm{R}-2,54-56\end{array}$ & $\begin{array}{l}685.23 \\
685.84\end{array}$ & $\begin{array}{l}+ \\
+\end{array}$ & $\begin{array}{l}+ \\
+\end{array}$ & + & + & & & $\begin{array}{l}+ \\
+\end{array}$ & & & $\begin{array}{l}+ \\
+\end{array}$ & & $\begin{array}{l}+ \\
+\end{array}$ & $\begin{array}{l}+ \\
+\end{array}$ & & $\begin{array}{l}+ \\
+\end{array}$ \\
\hline 4 & $66 \mathrm{R}-2,124-126$ & 686.54 & + & + & + & + & & & + & & + & + & & + & + & + & + \\
\hline 4 & $66 \mathrm{R}-3,4-6$ & 686.84 & + & + & + & + & & & + & & & + & & + & + & + & + \\
\hline 4 & $66 \mathrm{R}-3,57-59$ & 687.37 & + & + & & & & & + & & & + & & + & + & + & + \\
\hline 4 & $66 R-3,111-113$ & $\begin{array}{l}687.91 \\
68871\end{array}$ & + & + & + & + & & & + & & & + & & + & + & t. & + \\
\hline 4 & $66 R-4,41-43$ & $\begin{array}{l}688.71 \\
689.58\end{array}$ & + & + & & + & & & + & & & + & & + & \pm & + & + \\
\hline 4 & $\begin{array}{l}66 \mathrm{R}-4,128-130 \\
66 \mathrm{R}-5,49-51\end{array}$ & $\begin{array}{l}689.58 \\
69029\end{array}$ & $\begin{array}{lll}+ \\
+\end{array}$ & $\stackrel{+}{+}$ & t & $\begin{array}{l}+ \\
+\end{array}$ & + & & $\begin{array}{l}+ \\
+\end{array}$ & & $\stackrel{+}{+}$ & + & & + & + & + & + \\
\hline $\begin{array}{l}4 \\
4\end{array}$ & $\begin{array}{l}66 \mathrm{R}-5,49-51 \\
66 \mathrm{R}-6,43-45\end{array}$ & $\begin{array}{l}690.29 \\
691.73\end{array}$ & $\begin{array}{lll}+ \\
+\end{array}$ & $\begin{array}{lll}+ \\
+\end{array}$ & + & + & & & $\stackrel{+}{+}$ & & $\begin{array}{l}+ \\
+\end{array}$ & $\begin{array}{l}+ \\
+\end{array}$ & & $\begin{array}{l}+ \\
+\end{array}$ & $\begin{array}{lll}+ \\
+\end{array}$ & + & $\begin{array}{l}+ \\
+\end{array}$ \\
\hline 4 & $7 \mid R-1,64-66$ & 732.84 & + & $\begin{array}{l}t \\
+\end{array}$ & + & + & & & $\begin{array}{l}+ \\
+\end{array}$ & & $\begin{array}{l}+ \\
+\end{array}$ & $\begin{array}{llll}+ \\
+\end{array}$ & & $\begin{array}{lll}+ \\
+\end{array}$ & $\begin{array}{l}+ \\
+\end{array}$ & + & $\begin{array}{l}+ \\
+\end{array}$ \\
\hline 4 & $7 \mid \mathrm{R}-2,49-51$ & 734.19 & $\begin{array}{l}+ \\
+\end{array}$ & $\begin{array}{l}+ \\
+\end{array}$ & + & + & & & + & & $\begin{array}{l}+ \\
+\end{array}$ & + & & $\begin{array}{l}+ \\
+\end{array}$ & $\begin{array}{lll}+ \\
+\end{array}$ & + & $\begin{array}{l}+ \\
+\end{array}$ \\
\hline 4 & $7 \mid R-2,145-147$ & 735.15 & + & + & & & & & + & & + & + & & + & + & & + \\
\hline 4 & $78 \mathrm{R}-1,33-35$ & 799.33 & + & + & & & & & + & & + & + & & + & + & + & 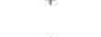 \\
\hline 4 & $78 \mathrm{R}-1,118-120$ & 800.18 & + & + & + & & & & + & & + & + & & + & + & 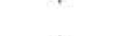 & + \\
\hline 4 & $78 \mathrm{R}-2,12-14$ & 800.62 & + & + & + & & + & & + & & + & + & & + & & + & \\
\hline 4 & $78 \mathrm{R}-2,142-144$ & 801.85 & + & + & & & + & & + & & + & + & & + & + & + & + \\
\hline 4 & $78 R-3,46-48$ & 802.4 & + & + & & & & & + & & + & + & & + & & + & + \\
\hline 4 & $78 R-3,98-100$ & 802.98 & + & + & & & + & & + & & + & + & & + & & + & + \\
\hline 4 & $78 R-3,130-132$ & 803.23 & + & + & & & + & & + & & + & + & & + & & + & + \\
\hline 4 & $78 R-4,27-29$ & 803.77 & + & + & & & & & + & & + & + & Gypsum & + & + & + & + \\
\hline 4 & $78 \mathrm{R}-4,40-42$ & 803.9 & + & + & & & + & & + & & + & + & & + & & + & + \\
\hline 4 & $\begin{array}{l}79 \mathrm{R}-1,18-20 \\
70 \mathrm{P}-2\end{array}$ & $\begin{array}{l}808.88 \\
811.23\end{array}$ & + & + & t & & 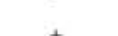 & & + & & 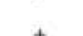 & + & & + & + & + & + \\
\hline 4 & $\begin{array}{l}79 \mathrm{R}-2,103-105 \\
70 \mathrm{R}-3\end{array}$ & $\begin{array}{l}811.23 \\
81273\end{array}$ & $\stackrel{+}{+}$ & $\begin{array}{l}+ \\
+\end{array}$ & + & & + & & + & & + & + & & + & + & & + \\
\hline $\begin{array}{l}4 \\
4\end{array}$ & $80 R-1,125-127$ & $\begin{array}{l}812.73 \\
819.55\end{array}$ & $\begin{array}{l}+ \\
+\end{array}$ & $\begin{array}{lll}+ \\
+\end{array}$ & & & + & & $\begin{array}{lll}+ \\
+\end{array}$ & & $\begin{array}{l}+ \\
+\end{array}$ & $\begin{array}{llll}+ \\
+\end{array}$ & & $\begin{array}{llll}+ \\
+\end{array}$ & & & \\
\hline 4 & $80 R-4,19-21$ & 822.99 & + & & & & + & & + & & + & + & & + & & & + \\
\hline 4 & $80 \mathrm{R}-4,43-45$ & 823.23 & + & & & & + & & + & & + & + & & + & & & + \\
\hline 4 & $80 R-4,129-131$ & 824.09 & + & & & & $r$ & & + & & + & + & & + & + & & + \\
\hline 4 & $80 \mathrm{R}-5,53-55$ & 824.83 & + & & & & & & + & & + & + & & + & + & & \\
\hline 4 & $80 \mathrm{R}-5,86-88$ & 825.16 & + & & & & & & + & & + & + & & + & + & & + \\
\hline 4 & $80 R-6,19-21$ & 825.99 & + & & & & & & + & & + & + & & + & & & \\
\hline 4 & $81 R-1,14-16$ & $\begin{array}{l}828.14 \\
88853\end{array}$ & & & & & & & & & + & + & & + & & & \\
\hline 4 & $81 R-1,53-55$ & 828.53 & & & & & + & & & & + & + & & + & & & \\
\hline $\begin{array}{l}4 \\
4\end{array}$ & $\begin{array}{l}81 R-2,18-20 \\
81 R-2\end{array}$ & $\begin{array}{l}829.68 \\
830.04\end{array}$ & $\stackrel{+}{+}$ & & & & & & $\begin{array}{lll}+ \\
+\end{array}$ & & + & $\stackrel{+}{+}$ & & $\begin{array}{l}+ \\
+\end{array}$ & & + & \\
\hline $\begin{array}{l}4 \\
4\end{array}$ & $\begin{array}{l}81 \mathrm{R}-2,54-56 \\
93 \mathrm{R}-2,7-9\end{array}$ & $\begin{array}{l}830.04 \\
935.17\end{array}$ & $\begin{array}{l}+ \\
+\end{array}$ & & & & & & $\begin{array}{lll}+ \\
+\end{array}$ & & + & + & Biotite & $\begin{array}{l}+ \\
+\end{array}$ & + & + & + \\
\hline 4 & $93 \mathrm{R}-2,69-71$ & 935.79 & + & + & & & & & + & & + & + & & + & & & 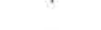 \\
\hline 4 & $93 \mathrm{R}-2,137-139$ & 936.47 & & + & & & + & & + & & + & + & & + & + & & + \\
\hline 4 & $93 R-3,45-47$ & 937.05 & & + & & & + & & + & & + & + & & + & + & & t \\
\hline 4 & $93 R-4,110-112$ & 939.2 & + & + & & & 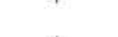 & & + & & + & + & & + & + & & \\
\hline 4 & $94 \mathrm{R}-1,21-23$ & 943.51 & + & + & & & + & & + & & + & + & & + & & & \\
\hline 4 & $94 \mathrm{R}-1.97-99$ & 944.27 & + & + & & & + & & + & & + & + & & + & & & \\
\hline 4 & $94 \mathrm{R}-1,138-140$ & $\begin{array}{l}944.68 \\
09578\end{array}$ & + & + & & & + & & + & & + & + & & + & & + & + \\
\hline 4 & 94R-2, 48-50 & 945.28 & + & + & & & + & & + & & + & + & & + & & & + \\
\hline
\end{tabular}



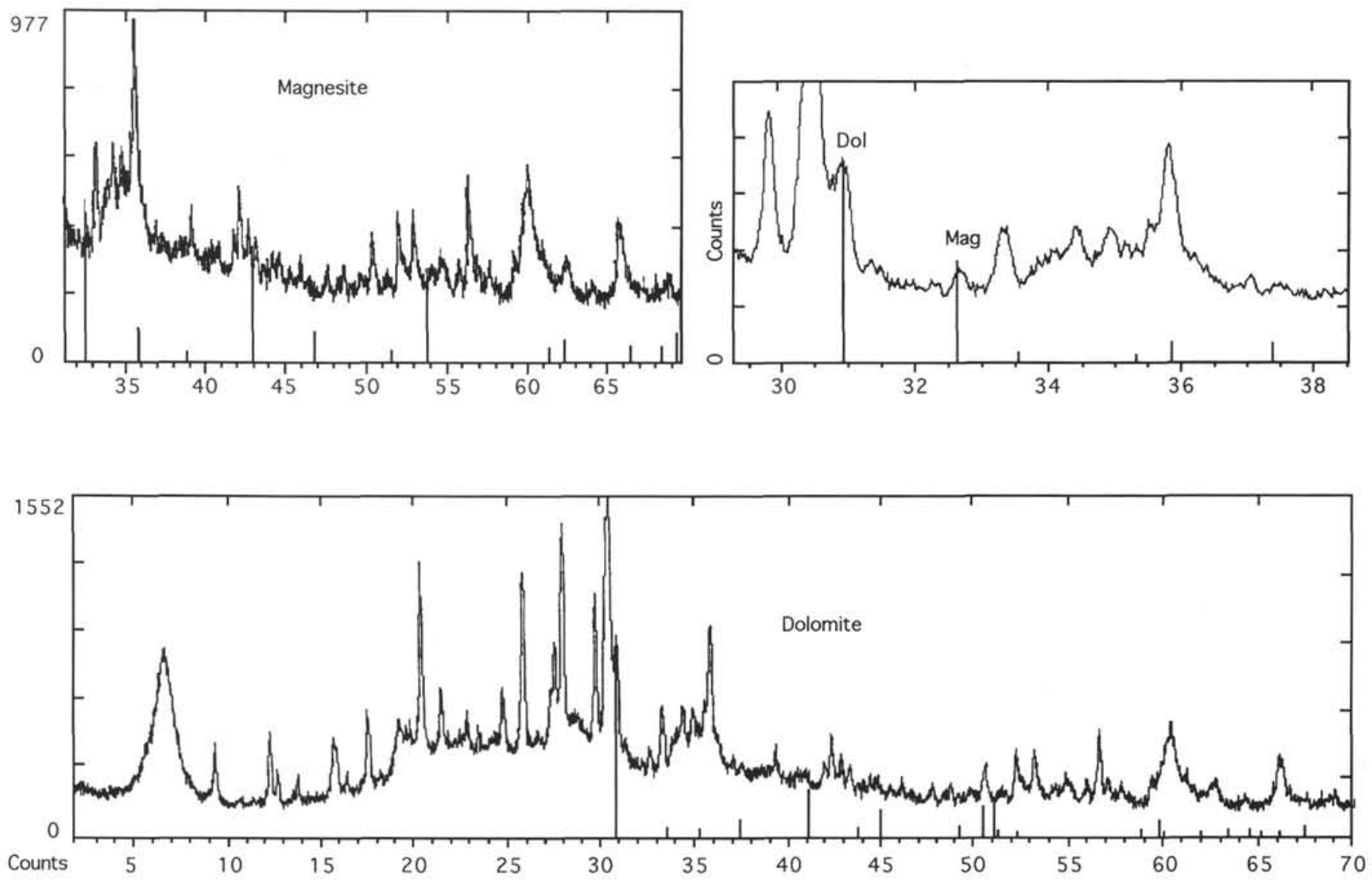

Figure 8. Dolomite and magnesite (Sample 134-832B-94R-2, 102-104 cm) XRD spectra with associated zeolites (phillipsite, analcime, and chabazite) and smectites (saponite). Markers of the JCPDS reference, quoted at the bottom of the figures, are superimposed on the spectra.

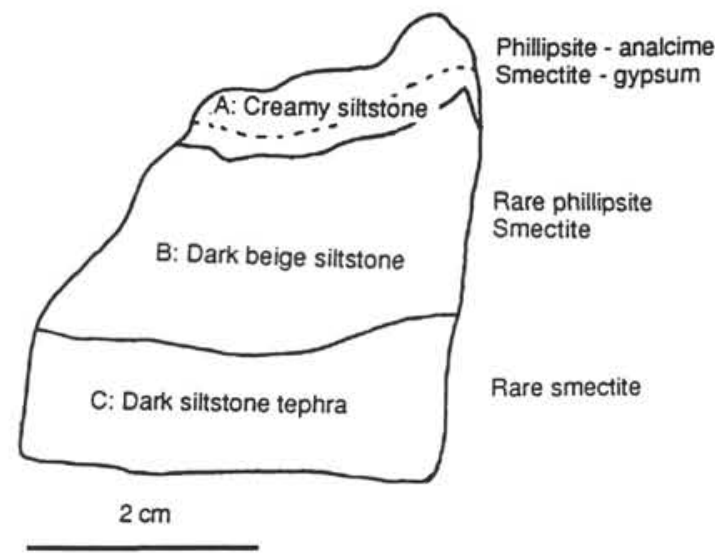

Figure 9. Small-scale sampling in Sample 134-832B-36R-1, 158-164 cm. One sample of each facies (A, B, and C) is analyzed with XRD. It shows the contact between a non-altered tephra and a zeolitized siltstone over $4 \mathrm{~cm}$.

volcaniclastic sediments. A level (number 16, Sample 134-832B94R-2, 102-104 cm, $1041.52 \mathrm{mbsf}$ ) is highly Mg-enriched: occurrence of magnesite, dolomite, and saponite ( $\mathrm{Mg}$-smectite) are noticed with XRD analysis. In the bottom of Site $833, \mathrm{Mg}$ carbonates or authigenic calcite appear near the sill intrusions. Nevertheless, the circulations of $\mathrm{Mg}$ fluids, noticeable on the deeper parts of both sites, seems to be (or have been) stronger on Site 832 .

Based on the evolution of $\mathrm{CaO}, \mathrm{CO}_{3}, \mathrm{Sr}$, and $\mathrm{Mg}$, compared to mineral occurrences, we demonstrate a specific "zonation" in the stratigraphic column. The deeper part of Site 832 is affected by $\mathrm{Mg}$ fluids. The authigenic minerals phases are predominant around the area of the sill intrusions of the Site 833. This mineralogical zonation of the stratigraphic column is also related to the primary porosity of rocks, as already mentioned above. The zonation is related to fluids, which affect the sill area for Site 833 .

The magnesium, based on bulk sediment analysis, permits us to subdivide the population of samples in two partitions with $\mathrm{MgO}>5 \%$, or $\mathrm{MgO}<5 \%$ (Fig. 13). Related with REE composition, $\mathrm{MgO}$ is an interesting factor to differentiate the geochemical characteristic of the deposits. This will be discuss down below.

\section{Volcaniclastic Component and Authigenic Mineral Influences on Bulk Chemical Composition}

Bulk sediment chemical analyses suggest that primary volcaniclastic components in the North Aoba Basin sediments exhibit three geochemical trends: calc-alkaline, high $\mathrm{K}$, and low $\mathrm{K}$ series (Figs. 14 and $15)$. The oxides values were calculated on anhydrous and carbonate free basis. We assume that measured $\mathrm{K}_{2} \mathrm{O}$ is representative of primary volcanic components, because volcaniclastic deposits are altered in the intermediate and deeper parts of the holes. It is true that potassium is one of the mobilized (leached) element by alteration mechanisms. Phillipsite, one of the authigenic minerals is a K-zeolite. Phillipsite is ubiquitous. $\mathrm{K}$ contained in the phillipsite may be derived from primary components far from the drilled area and transported by interstitial fluids. But the textural structure of these deposits shows phillipsite associated with the other authigenic minerals growths filling in the porosity of the rocks. We may then suppose that the mobilized $\mathrm{K}$ has 
Table 6. Major elements analyses, Holes 833A and 833B. The numbering refers to samples for diagrams or triplot figures.

\begin{tabular}{|c|c|c|c|c|c|c|c|c|c|c|c|c|c|c|c|}
\hline \multirow[b]{2}{*}{ Unit } & \multirow[b]{2}{*}{$N$} & \multirow[b]{2}{*}{ Sample $(\mathrm{cm})$} & \multirow[b]{2}{*}{$\begin{array}{l}\text { Depth } \\
\text { (mbsf) }\end{array}$} & \multicolumn{11}{|c|}{ Major elements (\%) } & \multirow[b]{2}{*}{ Total } \\
\hline & & & & $\mathrm{SiO}_{2}$ & $\mathrm{Al}_{2} \mathrm{O}_{3}$ & $\mathrm{TiO}_{2}$ & $\mathrm{Fe}_{2} \mathrm{O}_{3}$ & $\mathrm{CaO}$ & $\mathrm{MgO}$ & $\mathrm{K}_{2} \mathrm{O}$ & $\mathrm{Na}_{2} \mathrm{O}$ & $\mathrm{MnO}$ & $\mathrm{P}_{2} \mathrm{O}_{5}$ & LOI & \\
\hline $1 \mathrm{~A}$ & 1 & $134-832 \mathrm{~A}-2 \mathrm{H}-2,6-8$ & 7.4 & 54.04 & 16.51 & 0.77 & 9.08 & 5.66 & 2.47 & 3.15 & 4.75 & 0.2 & 0.43 & 2.59 & 99.65 \\
\hline $1 \mathrm{~A}$ & 2 & $134-832 \mathrm{~A}-19 \mathrm{H}-1,85-87$ & 141.85 & 56.54 & 14.38 & 0.6 & 7.45 & 6.09 & 2.31 & 2.04 & 4.47 & 0.16 & 0.2 & 5.47 & 99.71 \\
\hline IB & 3 & $134-832 \mathrm{~B}-23 \mathrm{R}-3,42-45$ & 360.02 & 43.72 & 13.32 & 0.56 & 7.28 & 13.76 & 4.32 & 0.88 & 2.54 & 0.13 & 0.11 & 3.12 & 99.73 \\
\hline 3 & 4 & $134-832 B-36 R-1,108-110$ & 481.88 & 50.21 & 14.63 & 0.8 & 8.46 & 9.19 & 2.5 & 2.12 & 3.75 & 0.17 & 0.28 & 7.63 & 99.74 \\
\hline 3 & 5 & 134-832B-35R-2, 91-93 & 512.21 & 36.72 & 12.1 & 0.52 & 5.8 & 20.06 & 2.91 & 1.27 & 2.41 & 0.13 & 0.11 & 17.67 & 99.7 \\
\hline 3 & 6 & $134-832 \mathrm{~B}-40 \mathrm{R}-2,23-25$ & 521.23 & 36.87 & 12.3 & 0.44 & 7.58 & 19.28 & 4.24 & 0.34 & 2.11 & 0.16 & 0.1 & 16.32 & 99.74 \\
\hline 4 & 7 & $134-832 \mathrm{~B}-51 \mathrm{R}-1,26-27$ & 625.96 & 45.15 & 13.0 & 0.59 & 9.28 & 9.28 & 7.63 & 0.6 & 1.87 & 0.16 & 0.16 & 12.00 & 99.72 \\
\hline 4 & 8 & 134-832B-52R1, 35-37 & 635.65 & 43.5 & 11.44 & 0.79 & 9.96 & 11.5 & 8.75 & 1.01 & 1.97 & 0.17 & 0.17 & 10.49 & 99.75 \\
\hline 4 & 9 & 134-832B-52R-1,115-117 & 636.45 & 42.82 & 14.21 & 0.78 & 9.14 & 9.28 & 5.66 & 0.8 & 3.45 & 0.15 & 0.2 & 13.26 & 99.75 \\
\hline 4 & 10 & $134-832 \mathrm{~B}-52 \mathrm{R}-3,25-27$ & 638.61 & 44.65 & 12.38 & 0.68 & 9.91 & 9.41 & 8.53 & 0.91 & 3.00 & 0.17 & 0.17 & 9.94 & 99.75 \\
\hline 6 & 11 & $134-832 \mathrm{~B}-83 \mathrm{R}-3,69-72$ & 936.99 & 47.17 & 12.69 & 0.6 & 7.63 & 7.69 & 7.1 & 0.91 & 2.83 & 0.14 & 0.1 & 12.9 & 99.76 \\
\hline 6 & 12 & $134-832 \mathrm{~B}-84 \mathrm{R}-1,14-15$ & 943.04 & 51.5 & 16.64 & 0.96 & 7.19 & 4.00 & 2.77 & 1.37 & 3.79 & 0.05 & 0.08 & 11.39 & 99.74 \\
\hline 7 & 13 & 134-832B-85R-4, 17-19 & 957.27 & 47.34 & 13.46 & 0.59 & 6.5 & 7.44 & 2.5 & 1.2 & 2.91 & 0.08 & 0.11 & 17.31 & 99.44 \\
\hline 7 & 14 & 134-832B-86R-2, 71-74 & 977.91 & 48.67 & 12.19 & 0.6 & 8.24 & 8.1 & 7.05 & 0.54 & 2.49 & 0.14 & 0.07 & 11.7 & 99.79 \\
\hline 7 & 15 & 134-832B-89R-3, $105-109$ & 994.85 & 47.53 & 13.3 & 0.86 & 10.64 & 6.91 & 3.89 & 0.86 & 3.52 & 0.19 & 0.1 & 12.03 & 99.83 \\
\hline 7 & 16 & $134-832 B-94 R-2,102-106$ & 1041.52 & 45.34 & 9.96 & 0.39 & 7.13 & 5.66 & 10.75 & 0.56 & 3.04 & 0.12 & 0.05 & 16.72 & 99.72 \\
\hline 7 & 17 & $134-832 \mathrm{~B}-99 \mathrm{R}-1,43-45$ & 1087.73 & 42.84 & 12.58 & 0.54 & 6.83 & 4.66 & 5.87 & 1.22 & 3.58 & 0.11 & 0.07 & 21.46 & 99.76 \\
\hline 7 & 18 & $134-832 \mathrm{~B}-100 \mathrm{R}-4,42-47$ & 1101.92 & 50.12 & 15.25 & 0.64 & 7.6 & 7.94 & 6.44 & 0.63 & 2.75 & 0.14 & 0.12 & 8.15 & 99.78 \\
\hline
\end{tabular}

Table 7. Major elements analysis, Holes 833A and 833B. The numbering refers to samples for diagrams or triplot figures.

\begin{tabular}{|c|c|c|c|c|c|c|c|c|c|c|c|c|c|c|c|}
\hline \multirow[b]{2}{*}{ Unit } & \multirow[b]{2}{*}{$N$} & \multirow[b]{2}{*}{ Sample $(\mathrm{cm})$} & \multirow{2}{*}{$\begin{array}{l}\text { Depth } \\
\text { (mbsf) }\end{array}$} & \multicolumn{12}{|c|}{ Major elements (\%) } \\
\hline & & & & $\mathrm{SiO}_{2}$ & $\mathrm{Al}_{2} \mathrm{O}_{3}$ & $\mathrm{Fe}_{2} \mathrm{O}_{3}$ & $\mathrm{MnO}$ & $\mathrm{MgO}$ & $\mathrm{CaO}$ & $\mathrm{Na}_{2} \mathrm{O}$ & $\mathrm{K} 2 \mathrm{O}$ & $\mathrm{TiO}_{2}$ & $\mathrm{P}_{2} \mathrm{O}_{5}$ & LOI & Total \\
\hline $1 \mathrm{~A}$ & 1 & $134-833 \mathrm{~A}-3 \mathrm{H}-1,84-86$ & 19.84 & 46.53 & 15,11 & 11.73 & 0.19 & 4.83 & 10.00 & 3.44 & 1.70 & 0.79 & 0.28 & 5.04 & 99.64 \\
\hline $2 \mathrm{~B}$ & 2 & $134-833 \mathrm{~B}-13 \mathrm{R}-1,33-35$ & 193.43 & 42.65 & 12.91 & 6.07 & 0.22 & 2.91 & 16.46 & 2.77 & 1.41 & 0.51 & 0.08 & 13.76 & 99.75 \\
\hline 3 & 3 & $134-833 \mathrm{~B}-32 \mathrm{R}-1,90-92$ & 376.7 & 41.03 & 13.66 & 7.08 & 0.10 & 5.19 & 9.21 & 4.29 & 0.69 & 0.56 & 0.14 & 16.83 & 98.78 \\
\hline 3 & 4 & $134-833 \mathrm{~B}-39 \mathrm{R}-1,86-88$ & 444.06 & 45.12 & 14.73 & 8.19 & 0.15 & 5.51 & 7.00 & 5.08 & 0.43 & 0.64 & 0.10 & 12.82 & 99.77 \\
\hline 3 & 5 & $134-833 \mathrm{~B}-39 \mathrm{R}-3,23-25$ & 444.43 & 45.28 & 14.25 & 9.21 & 0.15 & 8.00 & 9.05 & 2.62 & 0.77 & 0.63 & 0.05 & 9.71 & 99.72 \\
\hline 3 & 6 & $134-833 \mathrm{~B}-47 \mathrm{R}-2,29-31$ & 501.79 & 46.71 & 12.75 & 9.07 & 0.15 & 8.91 & 11.33 & 1.58 & 0.15 & 0.52 & 0.03 & 8.57 & 99.77 \\
\hline 3 & 7 & $134-833 \mathrm{~B}-47 \mathrm{R}-4,130-132$ & 505.8 & 46.78 & 14.30 & 9.28 & 0.15 & 8.16 & 10.49 & 1.97 & 0.26 & 0.56 & 0.07 & 7.77 & 99.79 \\
\hline 3 & 8 & $134-833 \mathrm{~B}-47 \mathrm{R}-6,35-37$ & 507.85 & 46.82 & 16.96 & 8.55 & 0.13 & 5.82 & 9.80 & 3.40 & 0.07 & 0.60 & 0.06 & 7.60 & 99.81 \\
\hline 3 & 9 & $134-833 \mathrm{~B}-53 \mathrm{R}-1,23-25$ & 558.13 & 44.17 & 14.81 & 8.55 & 0.14 & 7.25 & 9.71 & 2.41 & 0.22 & 0.54 & 0.05 & 11.92 & 99.77 \\
\hline 3 & 10 & $134-833 B-53 R-1,40-42$ & 558.3 & 44.02 & 14.63 & 7.94 & 0.14 & 7.30 & 9.71 & 2.41 & 0.22 & 0.48 & 0.08 & 12.84 & 99.77 \\
\hline 3 & 11 & $134-833 B-53 R-3,29-31$ & 561.19 & 45.17 & 13.58 & 8.44 & 0.15 & 8.73 & 9.69 & 2.20 & 0.83 & 0.51 & 0.04 & 10.42 & 99.76 \\
\hline 3 & 12 & 134-833B-53R-6, 15-17 & 565.55 & 44.12 & 13.46 & 8.38 & 0.14 & 6.78 & 10.30 & 4.15 & 0.30 & 0.48 & 0.05 & 11.65 & 99.81 \\
\hline 3 & 13 & $3 \mathrm{~B}-54 \mathrm{R}-5,55-57$ & 574.35 & 44.21 & 16.2 & 8.69 & 0.13 & 6.37 & 9.24 & 3.34 & 0.59 & 0.69 & 0.07 & 10.24 & 99.77 \\
\hline 3 & 14 & $134-833 \mathrm{~B}-54 \mathrm{R}-7,22-24$ & 577.02 & 45.2 & 14.16 & 9.24 & 0.15 & 7.69 & 9.60 & 2.27 & 0.53 & 0.64 & 0.05 & 10.23 & 99.76 \\
\hline 4 & 15 & $134-833 B-55 R-5,65-67$ & 584.35 & 44.47 & 16.85 & 7.83 & 0.12 & 5.00 & 11.25 & 2.20 & 0.40 & 0.60 & 0.06 & 10.95 & 99.73 \\
\hline 4 & 16 & 134-833B-55R-6, 113-115 & 586.33 & 44.52 & 14.78 & 8.39 & 0.13 & 6.58 & 10.58 & 1.70 & 0.64 & 0.56 & 0.04 & 11.86 & 99.78 \\
\hline 4 & 17 & 134-833-B65-RI, 138-140 & 675.58 & 41.4 & 14.01 & 6.94 & 0.07 & 4.00 & 10.80 & 2.61 & 1.26 & 0.58 & 0.14 & 17.95 & 99.76 \\
\hline 4 & 18 & $134-833 \mathrm{~B}-65 \mathrm{R}-3,8-85$ & 678.03 & 44.78 & 14 & 7.99 & 0.15 & 5.41 & 9.46 & 3.16 & 0.32 & 0.71 & 0.17 & 12.77 & 99.77 \\
\hline 4 & 19 & $134-833 \mathrm{~B}-65 \mathrm{R}-4,134-136$ & 680.04 & 45.06 & 14.83 & 6.75 & 0.12 & 4.89 & 11.23 & 2.66 & 0.34 & 0.51 & 0.12 & 13.25 & 99.76 \\
\hline 4 & 20 & $134-833 B-65 R-6,101-103$ & 682.71 & 44.65 & 13.1 & 9.07 & 0.08 & 4.51 & 9.25 & 1.47 & 1.00 & 0.60 & 0.02 & 15.94 & 99.69 \\
\hline 4 & 21 & $134-833 \mathrm{~B}-66 \mathrm{R}-3,4-6$ & 686.84 & 43.92 & 15.61 & 8.41 & 0.13 & 5.79 & 9.38 & 2.67 & 0.45 & 0.60 & trace & 12.78 & 99.74 \\
\hline 4 & 22 & $134-833 B-66 R-4,41-42$ & 688.71 & 42.07 & 14.26 & 8.21 & 0.14 & 6.29 & 8.33 & 4.15 & 0.44 & 0.56 & 0.10 & 15.22 & 99.77 \\
\hline 4 & 23 & 134-833B-71R-1, $64-66$ & 732.84 & 45.53 & 15.83 & 8.13 & 0.12 & 6.19 & 9.85 & 2.31 & 0.68 & 0.60 & 0.03 & 10.33 & 99.60 \\
\hline 4 & 24 & $134-833 B-7 \mid R-2,49-51$ & 734.19 & 35.02 & 11.91 & 6.50 & 0.14 & 3.59 & 17.63 & 2.86 & 0.63 & 0.50 & 0.14 & 20.87 & 99.79 \\
\hline 4 & 25 & $134-833 \mathrm{~B}-78 \mathrm{R}-2,12-14$ & 800.62 & 23.26 & 7.91 & 4.30 & 0.25 & 2.45 & 29.57 & 1.45 & 0.83 & 0.32 & 0.30 & 29.08 & 99.72 \\
\hline 4 & 26 & 134-833B-78R-4, 27-29 & 803.77 & 40.65 & 12.91 & 8.35 & 0.14 & 6.24 & 8.39 & 4.55 & 0.68 & 0.52 & 0.11 & 17.24 & 99.78 \\
\hline 4 & 27 & $134-833 \mathrm{~B}-79 \mathrm{R}-1,18-20$ & 808.88 & 33.52 & 11.07 & 6.41 & 0.15 & 4.30 & 18.39 & 3.64 & 0.64 & 0.44 & 0.13 & 21.08 & 99.77 \\
\hline 4 & 28 & $134-833 B-79 R-2,103-105$ & 811.23 & 38.02 & 12.96 & 6.75 & 0.14 & 3.58 & 14.91 & 2.65 & 1.29 & 0.56 & 0.14 & 18.74 & 99.74 \\
\hline 4 & 29 & $134-833 \mathrm{~B}-80 \mathrm{R}-5,53-55$ & 824.83 & 40.67 & 13.23 & 7.10 & 0.12 & 2.66 & 10.48 & 2.40 & 1.38 & 0.64 & 0.24 & 20.79 & 99.71 \\
\hline 4 & 30 & $134-833 \mathrm{~B}-81 \mathrm{R}-2,18-20$ & 829.68 & 38.84 & 11.05 & 6.30 & 0.15 & 1.85 & 18.66 & 1.45 & 1.31 & 0.60 & 0.06 & 19.45 & 99.72 \\
\hline 5 & 31 & $134-833 B-93 R-3,45-47$ & 937.05 & 42.15 & 12.60 & 7.94 & 0.16 & 2.25 & 11.74 & 2.58 & 3.00 & 0.68 & 0.50 & 15.80 & 99.40 \\
\hline 5 & 32 & 134-833B- $94 \mathrm{R}-2,48-50$ & 945.28 & 37.64 & 10.75 & 5.44 & 0.11 & 2.00 & 18.76 & 1.87 & 1.82 & 0.55 & 0.20 & 20.55 & 99.69 \\
\hline
\end{tabular}

not been transported very far and $\mathrm{K}$ utilized in the formation of authigenic mineral is locally derived. The bulk rock analyses may give a signal that is representative of the original content.

Based on $\mathrm{SiO}_{2} / \mathrm{KO}$ relative ratio, Site 832 , the deep basin site, contains a greater proportion of calc-alkaline composition primary components. Site 833 , the site located nearer the basin margin, contains both calc-alkaline and low-K series primary magmatic components. High $\mathrm{K}$ composition of primary magmatic components are more rare and located in the upper deposits. If one considers $\mathrm{SiO}_{2} / \mathrm{K}_{2} \mathrm{O}$ relative ratio calculated on anhydrous and carbonate-free basis (Figs. 14 and 15 ) the samples measured fall in the basalt to basaltic andesite range. Both sites show some measured samples that fall also in the andesite range. These trends are compatible with petrological and geochemical analyses on lavas (Collot, Greene, Stokking, et al., 1992). The volcanic print seems globally perdurable to the alteration process.

Figure 11 shows positive $(\mathrm{P})$ and negative $(\mathrm{N})$ correlations between various chemical components measured in the bulk sediment from Sites 832 and 833 . These diagrams are used to illustrate associations between chemical parameters, which may be derived from primary volcanogenic components, and to look for deviations from expected correlation patterns. Deviations from expected patterns may indicated chemical alteration of the bulk sediment, with loss or gain of the components examined.

Bulk sediment $\mathrm{K}_{2} \mathrm{O}, \mathrm{Al}_{2} \mathrm{O}_{3}, \mathrm{TiO}_{2}, \mathrm{MgO}$, and total $\mathrm{Fe}$ are considered to be derived from primary volcanogenic components. Higher concentrations of elements such as $\mathrm{Al}, \mathrm{Ti}, \mathrm{Mg}, \mathrm{K}, \mathrm{V}, \mathrm{Fe}$ are associated with volcaniclastic phases in the sediments (Hodkinson and Cronan, 1991). But superimposed on this general pattern, is the effect of alteration (authigenic input) reflected in the variation in concentration of elements such as $\mathrm{Al}, \mathrm{K}, \mathrm{Mg}, \mathrm{Fe}$, and also $\mathrm{Mn}, \mathrm{Cu}, \mathrm{Zn}, \mathrm{Ni}$, and $\mathrm{Co}$. Thus, correlation of other oxides and elements with these major oxides may be used to confirm the chemical character of the primary volcanogenic components contained in the sediments of North Aoba Basin and to establish the alteration effect. 
Table 8. Minor and rare earth elements, Holes 832A and 832B. The numbering refers to samples for diagrams or triplot figures.

\begin{tabular}{|c|c|c|c|c|c|c|c|c|c|c|c|c|c|c|c|c|c|c|c|c|c|}
\hline \multirow[b]{2}{*}{ Unit } & \multirow[b]{2}{*}{$N$} & \multirow[b]{2}{*}{ Sample $(\mathrm{cm})$} & \multirow{2}{*}{$\begin{array}{l}\text { Depth } \\
\text { (mbsf) }\end{array}$} & \multicolumn{18}{|c|}{ Minor elements (ppm) } \\
\hline & & & & $\mathrm{Ba}$ & $\mathrm{Be}$ & Co & $\mathrm{Cr}$ & $\mathrm{Cu}$ & Ga & $\mathrm{Nb}$ & $\mathrm{Ni}$ & $\mathrm{Rb}$ & Sc & $\mathrm{Sr}$ & $\mathrm{V}$ & $\mathrm{Zn}$ & $\mathrm{Zr}$ & $\mathrm{U}$ & Th & $\mathrm{Pb}$ & As \\
\hline $1 \mathrm{~A}$ & 1 & $134-832 \mathrm{~A}-2 \mathrm{H}-2,6-8$ & 7.40 & 822 & 0.8 & 22 & 9 & 173 & 16 & 1 & 14 & 55 & 12.0 & 773 & 220 & 114 & 99 & 0.20 & 2.23 & 14 & 5.2 \\
\hline $1 \mathrm{~A}$ & 2 & $134-832 \mathrm{~A}-19 \mathrm{H}-1,85-87$ & 141.85 & 552 & 0.5 & 14 & 44 & 87 & 9 & $<5$ & 14 & 38 & 18.0 & 420 & 134 & 82 & $\mathrm{~s}$ & $<0.10$ & 0.77 & 8 & 4.9 \\
\hline 1B & 3 & $134-832 \mathrm{~B}-23 \mathrm{R}-3,42-45$ & 360.02 & 246 & $<0.5$ & 22 & 140 & 104 & 10 & $<5$ & 51 & 27 & 24.2 & 696 & 201 & 62 & 0 & $<0.10$ & $<0.10$ & 5 & 4.1 \\
\hline 3 & 4 & 134-832B-36R-1, 108-110 & 481.88 & 380 & 0.5 & 20 & 25 & 181 & 9 & $<5$ & 17 & 46 & 20.1 & 549 & 228 & 87 & 88 & $<0.10$ & 0.88 & 7 & 3.1 \\
\hline 3 & 5 & $134-832 \mathrm{~B}-35 \mathrm{R}-2,91-93$ & 512.21 & 255 & $<0.5$ & 18 & 86 & 127 & 6 & $<5$ & 33 & 29 & 25.7 & 659 & 187 & 50 & 43 & $<0.10$ & 0.01 & 5 & 2.9 \\
\hline 3 & 6 & $134-832 \mathrm{~B}-40 \mathrm{R}-2,23-25$ & 521.23 & 197 & $<0.5$ & 26 & 128 & 139 & 10 & $<5$ & 46 & 20 & 26.6 & 715 & 195 & 59 & 30 & 4.30 & 0.42 & 6 & 3.8 \\
\hline 4 & 7 & $134-832 B-5$ IR-1, 26-27 & 625.96 & 178 & 1.2 & 38 & 543 & 143 & 20 & $<5$ & 172 & 16 & 31.7 & 334 & 273 & 60 & 43 & $<0.10$ & 3.88 & 4 & 1.8 \\
\hline 4 & 8 & 134-832B-52R1, 35-37 & 635.65 & 145 & 1.2 & 37 & 284 & 100 & 24 & $<5$ & 80 & 20 & 42.2 & 446 & 293 & 64 & 51 & 1.34 & 2.49 & 3 & 1.5 \\
\hline 4 & 9 & 134-832B-52R-1,115-117 & 636.45 & 136 & 1.2 & 30 & 148 & 119 & 19 & $<5$ & 41 & 16 & 28.7 & 798 & 295 & 55 & 4 & $<0.10$ & 2.11 & 4 & 1.9 \\
\hline 4 & 10 & $134-832 \mathrm{~B}-52 \mathrm{R}-3,25-27$ & 63 & 152 & 1.2 & 38 & 310 & 113 & 19 & $<5$ & 92 & 19 & 35.7 & 259 & 310 & 67 & 47 & $<0.10$ & 1.22 & 4 & 1.6 \\
\hline 6 & 11 & $134-832 \mathrm{~B}-83 \mathrm{R}-3,69-72$ & 936.99 & 146 & 1 & 28 & 268 & 77 & 20 & $<5$ & 88 & 20 & 26.3 & 209 & 203 & 60 & 61 & $<0.10$ & 2.43 & 3 & 3.0 \\
\hline 6 & 12 & $134-832 \mathrm{~B}-84 \mathrm{R}-1,14-15$ & 943.04 & 187 & 0.6 & 24 & 56 & 51 & 19 & $<5$ & 26 & 28 & 27.8 & 399 & 166 & 103 & 81 & 1.18 & 1.57 & 3 & 24.0 \\
\hline 7 & 13 & $134-832 \mathrm{~B}-85 \mathrm{R}-4,17-19$ & 957.27 & 129 & 0.5 & 12 & 35 & 57 & 12 & $<5$ & 24 & 22 & 19.9 & 447 & 126 & 61 & 71 & $<0.10$ & 1.88 & 4 & 9.0 \\
\hline 7 & 14 & 134-832B-86R-2, 71-74 & 977.91 & 106 & 0.8 & 27 & 414 & 92 & 15 & $<5$ & 107 & 14 & 27.7 & 210 & 202 & 64 & 56 & $<0.10$ & 2.55 & 3 & 3.0 \\
\hline 7 & 15 & 134-832B-89R-3, 105-10 & 994.85 & 34 & 1.1 & 25 & 17 & 194 & 16 & $<5$ & 14 & 15 & 32.9 & 210 & 345 & 76 & 37 & $<0.10$ & 2.77 & 2 & 6.0 \\
\hline 7 & 16 & 134-832B-94R-2, 102-106 & 41.52 & 127 & 0.6 & 36 & 748 & 123 & 15 & $<5$ & 148 & 13 & 28.8 & 116 & 208 & 46 & 33 & $<0.10$ & 4.12 & 2 & 6.3 \\
\hline 7 & 17 & 134-832B-99R-1, 43-45 & 1087.73 & 159 & 0.8 & 23 & 246 & 116 & 12 & $<5$ & 60 & 24 & 26.1 & 255 & 211 & 55 & 46 & $<0.10$ & 1.24 & 3 & 4.2 \\
\hline 7 & 18 & $134-832 \mathrm{~B}-100 \mathrm{R}-4,42-47$ & 1101.92 & 129 & 0.8 & 25 & 112 & 84 & 17 & $<5$ & 40 & 15 & 26.1 & 213 & 213 & 57 & 68 & $<0.10$ & 1.89 & 3 & 3.6 \\
\hline
\end{tabular}

Table 9. Minor and rare earth elements (ppm), holes $833 \mathrm{~A}$ and $\mathrm{B}$. The numbering refers to samples for diagrams or triplots figures.

\begin{tabular}{|c|c|c|c|c|c|c|c|c|c|c|c|c|c|c|c|c|c|c|c|c|c|}
\hline \multirow[b]{2}{*}{ Unit } & \multirow[b]{2}{*}{$N$} & \multirow[b]{2}{*}{ Sample (cm) } & \multirow{2}{*}{$\begin{array}{c}\text { Depth } \\
\text { (m) }\end{array}$} & \multicolumn{18}{|c|}{ Trace elements (ppm) } \\
\hline & & & & $\mathrm{Ba}$ & $\mathrm{Be}$ & $\mathrm{Co}$ & $\mathrm{Cr}$ & $\mathrm{Cu}$ & Ga & $\mathrm{Nb}$ & $\mathrm{Ni}$ & $\mathrm{Rb}$ & $\mathrm{Sc}$ & $\mathrm{Sr}$ & $\mathrm{V}$ & $\mathrm{Zn}$ & $\mathrm{Zr}$ & $\mathrm{U}$ & Th & $\mathrm{Pb}$ & As \\
\hline IA & 1 & $134-833 \mathrm{~A}-3 \mathrm{H}-1,84-86$ & 19.84 & 416 & 0.8 & 41 & 99 & 291 & 16 & $<5$ & 41 & 38 & 24.78 & 885 & 316 & 86 & 55 & 0.63 & 1.38 & 10 & 3.3 \\
\hline $2 \mathrm{~B}$ & 2 & $134-833 \mathrm{~B}-13 \mathrm{R}-1,33-35$ & 193.43 & 462 & $<0.5$ & 16 & 75 & 87 & $<5$ & $<5$ & 25 & 31 & 23.78 & 592 & 176 & 57 & 60 & $<0.1$ & 1.14 & 7 & 2.2 \\
\hline 3 & 3 & $134-833 \mathrm{~B}-32 \mathrm{R}-1,90-92$ & 376.7 & 130 & 0.6 & 31 & 187 & 130 & 7 & 1 & 88 & 13 & 24.7 & 374 & 257 & 63 & 36 & 0.2 & 0.2 & 4 & 10 \\
\hline 3 & 4 & $134-833 \mathrm{~B}-39 \mathrm{R}-1,86-88$ & 444.06 & 56 & $<0.5$ & 22 & 123 & 206 & $<5$ & $<5$ & 45 & 18 & 21.1 & 156 & 211 & 60 & 52 & 0.75 & $<0.1$ & 7 & - \\
\hline 3 & 5 & $134-833 \mathrm{~B}-39 \mathrm{R}-3,23-25$ & 444.43 & 110 & $<0.5$ & 33 & 325 & 96 & $<5$ & $<5$ & 95 & 20 & 32.5 & 496 & 301 & 61 & 27 & $<0.1$ & $<0.1$ & 2 & 1.5 \\
\hline 3 & 6 & $134-833 \mathrm{~B}-47 \mathrm{R}-2,29-31$ & 501.79 & 69 & $<0.5$ & 36 & 393 & 126 & 23 & $<5$ & 105 & 16 & 40.2 & 349 & 299 & 62 & 20 & 0.93 & $<0.1$ & 4 & 0.7 \\
\hline 3 & 7 & $134-833 \mathrm{~B}-47 \mathrm{R}-4,130-132$ & 505.8 & 91 & $<0.5$ & 36 & 285 & 117 & 24 & 5 & 101 & 21 & 34.7 & 226 & 308 & 65 & 22 & $<0.1$ & $<0.1$ & 3 & 1.1 \\
\hline 3 & 8 & $134-833 \mathrm{~B}-47 \mathrm{R}-6,35-37$ & 507.85 & 51 & $<0.5$ & 28 & 210 & 159 & 19 & $<5$ & 60 & 16 & 29.5 & 235 & 298 & 63 & 26 & $<0.1$ & $<0.1$ & 4 & 0.9 \\
\hline 3 & 9 & 134-833B-53R-1, 23-25 & 558.13 & 43 & 0.6 & 35 & 267 & 113 & 15 & $<5$ & 94 & 13 & 33.4 & 294 & 263 & 65 & 37 & 1.84 & $<0.1$ & 2 & 1.2 \\
\hline 3 & 10 & $134-833 \mathrm{~B}-53 \mathrm{R}-1,40-42$ & 558.3 & 57 & 0.8 & 30 & 259 & 109 & 21 & $<5$ & 82 & 9 & 33.5 & 256 & 262 & 59 & 33 & $<0.1$ & 1.34 & 3 & 1.4 \\
\hline 3 & iI & $134-833 B-53 R-3,29-31$ & 561.19 & 136 & $<0.5$ & 36 & 447 & 154 & 27 & 5 & 132 & 24 & 37 & 275 & 261 & 61 & 31 & 0.78 & $<0.1$ & 3 & 1.6 \\
\hline 3 & 12 & $134-833 \mathrm{~B}-53 \mathrm{R}-6.15-17$ & 565.55 & 109 & $<0.5$ & 35 & 192 & 138 & 15 & $<5$ & 79 & 24 & 27.78 & 278 & 264 & 68 & 21 & $<0.1$ & $<0.1$ & 3 & 3.9 \\
\hline 3 & 13 & $134-833 B-54 R-5,55-57$ & 574.35 & 131 & $<0.5$ & 31 & 283 & 114 & 20 & $<5$ & 85 & 22 & 29.5 & 305 & 291 & 65 & 36 & 1.63 & 0.22 & 3 & 1.3 \\
\hline 3 & 14 & 134-833B-54R-7. 22-24 & 577.02 & 119 & $<0.5$ & 35 & 310 & 96 & 16 & $<5$ & 107 & 18 & 34.4 & 230 & 309 & 63 & 27 & $<0.1$ & $<0.1$ & 3 & 1.5 \\
\hline 4 & is & 134-833B-55R-5. 65-67 & 584.35 & 58 & $<0.5$ & 25 & 206 & 135 & 23 & $<5$ & 51 & 14 & 32 & 307 & 274 & 63 & 32 & 0.22 & $<0.1$ & 4 & 0.8 \\
\hline 4 & 16 & 134-833B-55R-6. $113-115$ & 586,33 & 56 & $<0.5$ & 33 & 238 & 130 & 16 & $<5$ & 70 & 17 & 32.2 & 409 & 260 & 61 & 33 & 0.88 & $<0.1$ & 3 & 0.9 \\
\hline 4 & 17 & $134-833 \mathrm{~B}-65 \mathrm{R}-1,138-140$ & 675.58 & 242 & 0.1 & 26 & 124 & 70 & 56 & 13 & 60 & 20 & 22.7 & 513 & 213 & 139 & 42 & 0.2 & 0.2 & 3 & 5 \\
\hline 4 & 18 & $134-833 \mathrm{~B}-65 \mathrm{R}-3,83-85$ & 678.03 & 44 & $<0.5$ & 24 & 130 & 236 & $<5$ & $<5$ & 74 & 16 & 23.28 & 389 & 249 & 70 & 63 & $<0.1$ & $<0.1$ & 4 & 3.2 \\
\hline 4 & 19 & $134-833 B-65 R-4.134-136$ & 680.04 & 84 & 0.8 & 30 & 172 & 167 & 16 & $<5$ & 72 & 10 & 25.7 & 719 & 230 & 61 & 48 & $<0.1$ & 1.4 & 4 & 4.1 \\
\hline 4 & 20 & 134-833B-65R-6, $101-103$ & 682.71 & 132 & $<0.5$ & 16 & 79 & 119 & $<5$ & $<5$ & 33 & 25 & 21 & 890 & 180 & 68 & 46 & 3.64 & 0.3 & 4 & 4.7 \\
\hline 4 & 21 & $134-833 \mathrm{~B}-66 \mathrm{R}-3,4-6$ & 686.84 & 56 & 0.6 & 24 & 369 & 112 & 22 & $<5$ & 96 & 19 & 32.7 & 471 & 302 & 44 & 31 & $<0.1$ & $<0.1$ & 2 & 1.3 \\
\hline 4 & 22 & $134-833 \mathrm{~B}-66 \mathrm{R}-4,41-43$ & 688.71 & 41 & $<0.5$ & 21 & 134 & 257 & $<5$ & $<5$ & 49 & 19 & 23.28 & 443 & 260 & 63 & 36 & 1.17 & $<0.1$ & 5 & 3.8 \\
\hline 4 & 23 & $134-833 \mathrm{~B}-71 \mathrm{R}-1.64-66$ & 732.84 & 108 & $<0.5$ & 32 & 314 & 112 & $<5$ & $<5$ & 77 & 23 & 32.2 & 1612 & 276 & 59 & 29 & $<0.1$ & $<0.1$ & 3 & 1.1 \\
\hline 4 & 24 & $134-833 \mathrm{~B}-71 \mathrm{R}-2,49-51$ & 734.19 & 69 & $<0.5$ & 19 & 84 & 176 & $<5$ & $<5$ & 46 & 24 & 24 & 488 & 160 & 63 & 47 & 2.89 & 0.62 & 16 & 7.1 \\
\hline 4 & 25 & $134-833 \mathrm{~B}-78 \mathrm{R}-2,12-14$ & 800.62 & 162 & 1 & 22 & 76 & 59 & 57 & 16 & 59 & 18 & 21.2 & 758 & 124 & 50 & 45 & 1.17 & 0.2 & 4 & 5.8 \\
\hline 4 & 26 & 134-833B-78R-4, 27-29 & 803.77 & 29 & 0.8 & 37 & 178 & 134 & 16 & $<5$ & 127 & 14 & 25.2 & 346 & 243 & 74 & 45 & $<0.1$ & $<0.1$ & 7 & 5.8 \\
\hline 4 & 27 & $134-833 \mathrm{~B}-79 \mathrm{R}-1,18-20$ & 808.88 & 23 & $<0.5$ & 16 & 140 & 154 & $<5$ & $<5$ & 43 & 28 & 24.6 & 492 & 162 & 63 & 41 & 1.6 & $<0.1$ & 6 & 2.1 \\
\hline 4 & 28 & 134-833B-79R-2, 103-105 & 811.23 & 245 & $<0.5$ & 20 & 141 & 158 & 5 & $<$ & 46 & 25 & 23.5 & 715 & 195 & 70 & 53 & 0.53 & 0.29 & 6 & 5.2 \\
\hline 4 & 29 & $134-833 \mathrm{~B}-80 \mathrm{R}-5,53-55$ & 824.83 & 338 & 1.1 & 11 & 60 & 132 & 18 & $<5$ & 27 & 27 & 17.7 & 717 & 149 & 68 & 114 & 1.61 & 2.66 & 8 & 18.5 \\
\hline 4 & 30 & $134-833 \mathrm{~B}-81 \mathrm{R}-2,18-20$ & 829.68 & 185 & $<0.5$ & 13 & 44 & 56 & $<5$ & $<5$ & 23 & 40 & 22.28 & 939 & 142 & 77 & 37 & 1.24 & $<0.1$ & 4 & 3 \\
\hline 5 & 31 & $134-833 \mathrm{~B}-93 \mathrm{R}-3,45-47$ & 937.05 & 237 & 1.1 & 17 & 14 & 212 & 10 & 1 & 19 & 41 & 16.1 & 3118 & 181 & 86 & 127 & 1.29 & 1.92 & 10 & 10.7 \\
\hline 5 & 32 & $134-833 \mathrm{~B}-94 \mathrm{R}-2,48-50$ & 945.28 & 190 & 1.2 & 19 & 45 & 45 & 56 & 15 & 35 & 40 & 20.2 & 919 & 152 & 69 & 59 & 0.2 & 0.2 & 4 & 8.4 \\
\hline
\end{tabular}

The mobilization of elements such as $\mathrm{Al}, \mathrm{Mg}, \mathrm{K}, \mathrm{Fe}$, and $\mathrm{V}$ is redox influenced or is affected by low temperature hydrothermal alteration. But, as stated above for the potassium, we assume this mobility relatively located to each altered levels. Bulk sediment analyses, compared to mineralogical evidences may be useful and valides to identify primary magmatic signals or authigenic signal.

Site 833 shows the following positive correlations (Fig. 11):

$\begin{array}{ll}\mathrm{K} & \mathrm{P}, \mathrm{Ba}, \mathrm{Rb}, \mathrm{Sr}, \mathrm{Zn}, \mathrm{Zr}, \mathrm{Light} \text { REE (La, Ce, Nd) } \\ \mathrm{Al} & \mathrm{V} \\ \mathrm{Ti} & \mathrm{Eu} \\ \mathrm{Mg} & \mathrm{Sc}, \mathrm{Ni}, \mathrm{Ga}, \mathrm{Cr}, \mathrm{Co}, \mathrm{V} \\ \mathrm{Fe} & \mathrm{Co}, \mathrm{Ti}, \mathrm{Mg}, \mathrm{V} \\ \mathrm{P} & \mathrm{Ba}, \mathrm{Be}, \mathrm{Cu}, \mathrm{Zn} \mathrm{Zr}, \mathrm{Pb}, \mathrm{REE}\end{array}$

and the following negative correlations:

$\mathrm{Mg} \quad \mathrm{La}, \mathrm{Zr}, \mathrm{Rb}, \mathrm{Ba}, \mathrm{P}, \mathrm{K}, \mathrm{Ca}$
$\mathrm{Ca}$

$\mathrm{P}$

$$
\mathrm{Al}, \mathrm{Fe}, \mathrm{Mn}, \mathrm{Mg}, \mathrm{Co}, \mathrm{Ni}, \mathrm{V}
$$

Site 832 shows the following positive correlations (Fig. 11):

$\begin{array}{ll}\mathrm{K} & \mathrm{Ba}, \mathrm{Rb}, \mathrm{Zr}, \mathrm{Pb}, \mathrm{REE} \\ \mathrm{Al} & \mathrm{Ti}, \mathrm{Zr}, \mathrm{Heavy} \mathrm{REE}(\mathrm{S}, \mathrm{Cr}, \mathrm{Ni}, \mathrm{Ga}, \mathrm{Cr}, \mathrm{Co} \\ \mathrm{Mg} & \mathrm{Cr}, \mathrm{Be}, \mathrm{Ga}, \mathrm{Sc}, \mathrm{V} \\ \mathrm{Fe} & \mathrm{Sr} \\ \mathrm{Ca} & \mathrm{Pb}, \mathrm{REE} \\ \mathrm{P} & \\ & \\ \text { and the following negative correlations: } \\ \mathrm{Al} & \mathrm{Mg}, \mathrm{Cr} \\ \mathrm{Mg} & \mathrm{K}, \mathrm{Pb}, \mathrm{HREE}(\mathrm{Yb}) \\ \mathrm{Ca} & \mathrm{Na}\end{array}$


Table 8 (continued).

\begin{tabular}{|c|c|c|c|c|c|c|c|c|c|c|c|c|c|c|c|c|}
\hline \multirow{2}{*}{ Unit } & \multirow[b]{2}{*}{$N$} & \multirow[b]{2}{*}{ Sample (cm) } & \multirow{2}{*}{$\begin{array}{l}\text { Depth } \\
\text { (mbsf) }\end{array}$} & \multicolumn{13}{|c|}{ REE (ppm) } \\
\hline & & & & $\mathrm{Y}$ & $\mathrm{La}$ & $\mathrm{Ce}$ & $\mathrm{Nd}$ & $\mathrm{Sm}$ & $\mathrm{Eu}$ & $\mathrm{Gd}$ & Dy & $\mathrm{Er}$ & $\mathrm{Yb}$ & Lu & $\mathrm{La} / \mathrm{Yb}$ & $\overline{\mathrm{Ce} / \mathrm{La}}$ \\
\hline $1 \mathrm{~A}$ & 1 & $134-832 \mathrm{~A}-2 \mathrm{H}-2,6-8$ & 7.40 & 17.4 & 16.4 & 32.2 & 16.9 & 4.1 & 1.18 & 3.17 & 2.8 & 1.43 & 1.63 & 0.23 & 10.0 & 2.0 \\
\hline $1 \mathrm{~A}$ & 2 & $134-832 \mathrm{~A}-19 \mathrm{H}-1,85-87$ & 141.85 & 28.5 & 14.5 & 32.6 & 20.5 & 5.6 & 1.40 & 5.90 & 5.2 & 3.1 & 3.00 & 0.50 & 4.8 & 2.2 \\
\hline 1B & 3 & $134-832 \mathrm{~B}-23 \mathrm{R}-3,42-45$ & 360.02 & 17.0 & 8.9 & 20.7 & 12.0 & 3.5 & 0.90 & 3.70 & 3.0 & 2.00 & 1.70 & 0.30 & 5.2 & 2.3 \\
\hline 3 & 4 & 134-832B-36R-1, 108-110 & 481.88 & 28.5 & 16.1 & 33.0 & 22.4 & 5.8 & 1.60 & 6.00 & 4.9 & 2.80 & 2.80 & 0.40 & 5.7 & 2.0 \\
\hline 3 & 5 & 134-832B-35R-2, 91-93 & 512.21 & 18.0 & 8.7 & 16.2 & 12.8 & 3.8 & 1.00 & 4.20 & 3.1 & 2.0 & 1.70 & 0.30 & 5.3 & 1.9 \\
\hline 3 & 6 & 134-832B-40R-2, 23-25 & 521.23 & 14.1 & 5.8 & 11.8 & 8.9 & 2.4 & 0.60 & 2.10 & 2.4 & 1.40 & 1.30 & 0.20 & 4.5 & 2.0 \\
\hline 4 & 7 & $134-832 \mathrm{~B}-51 \mathrm{R}-1,26-27$ & 625.96 & 11.4 & 9.4 & 21.9 & 13.4 & 3.3 & 0.90 & 3.00 & 2.2 & 1.20 & 1.10 & 0.20 & 8.6 & 2.3 \\
\hline 4 & 8 & 134-832B-52R1, 35-37 & 635.65 & 17.6 & 7.2 & 15.7 & 11.6 & 3.4 & 1.00 & 3.50 & 3.1 & 1.60 & 1.60 & 0.20 & 4.4 & 2.2 \\
\hline 4 & 9 & 134-832B-52R-1,115-117 & 636.45 & 16.4 & 9.0 & 19.4 & 13.1 & 3.3 & 1.10 & 3.20 & 3.0 & 1.40 & 1.60 & 0.20 & 5.7 & 2.4 \\
\hline 4 & 10 & 134-832B-52R-3, 2 & 638.61 & 14.0 & 6.7 & 15.7 & 10.6 & 2.9 & 0.90 & 3.00 & 2.6 & 1.30 & 1.40 & 0.20 & 4.9 & 2.2 \\
\hline 6 & 11 & $134-832 \mathrm{~B}-83 \mathrm{R}-3,69-72$ & 936.99 & 16.2 & 5.1 & 11.3 & 7.8 & 2.5 & 0.80 & 2.90 & 2.7 & 1.50 & 1.60 & 0.20 & 3.2 & 2.8 \\
\hline 6 & 12 & 134-832B-84R-1, 14-15 & 943.04 & 18.8 & 4.0 & 11.2 & 8.9 & 2.9 & 0.90 & 3.30 & 3.7 & 1.90 & 2.20 & 0.30 & 1.8. & 2.5 \\
\hline 7 & 13 & 134-832B-85R-4, $17-19$ & 957.27 & 16.8 & 7.4 & 18.2 & 12.2 & 3.3 & 0.90 & 3.30 & 3.2 & 1.70 & 1.80 & 0.20 & 4.1 & 2.5 \\
\hline 7 & 14 & 134-832B-86R-2, 71-74 & 977.91 & 11.6 & 3.2 & 7.6 & 5.0 & 1.7 & 0.50 & 1.90 & 2.00 & 1.10 & 1.20 & 0.20 & 2.6 & 2.4 \\
\hline 7 & 15 & $134-832 \mathrm{~B}-8$ & 994. & 17.2 & 1.4 & 4.5 & 4.4 & 1.7 & 0.60 & 2.10 & 2.8 & 1.70 & 1.80 & 0.30 & 0.8 & 3.3 \\
\hline 7 & 16 & 134-832B-94R-2, 102-106 & 1041.52 & 10.0 & 3.0 & 6.4 & 4.6 & 1.7 & 0.50 & 1.90 & 1.7 & 0.90 & 1.00 & 0.20 & 3.0 & 2.1 \\
\hline 7 & 17 & 134-832B-99R-1, 43-45 & 1087.73 & 13.1 & 4.3 & 9.5 & 6.3 & 1.8 & 0.60 & 2.00 & 2.2 & 1.30 & 1.30 & 0.20 & 3.3 & 2.2 \\
\hline 7 & 18 & $134-832 \mathrm{~B}-100 \mathrm{R}-4,42-47$ & 1101.92 & 17.2 & 7.3 & 15.3 & 9.6 & 2.6 & 0.80 & 2.80 & 2.9 & 1.40 & 1.70 & 0.20 & 4.4 & 2.1 \\
\hline
\end{tabular}

Table 9 (continued).

\begin{tabular}{|c|c|c|c|c|c|c|c|c|c|c|c|c|c|c|c|c|}
\hline \multirow[b]{2}{*}{ Unit } & \multirow[b]{2}{*}{$N$} & \multirow[b]{2}{*}{ Sample (cm) } & \multirow{2}{*}{$\begin{array}{l}\text { Depth } \\
\text { (m) }\end{array}$} & \multirow[b]{2}{*}{$\mathbf{Y}$} & \multicolumn{12}{|c|}{ REE (ppm) } \\
\hline & & & & & La & $\mathrm{Ce}$ & Nd & $\mathrm{Sm}$ & Eu & Gd & Dy & $\mathrm{Er}$ & $\mathrm{Yb}$ & Lu & $\mathrm{La} / \mathrm{Yb}$ & $\mathrm{Ce} / \mathrm{La}$ \\
\hline $1 \mathrm{~A}$ & 1 & $134-833 \mathrm{~A}-3 \mathrm{H}-1,84-86$ & 19.84 & 17.75 & 15.51 & 26.49 & 18.9 & 4.14 & 1. & 3.46 & 3.19 & 1.45 & 1.55 & 0.23 & 10.0 & 1.7 \\
\hline $2 \mathrm{~B}$ & 2 & $134-833 \mathrm{~B}-13 \mathrm{R}-1,33-35$ & 193.43 & 19.25 & 11.6 & 23,43 & 14.45 & 3.77 & 0.95 & 4.33 & 3.34 & 2.15 & 1.86 & 0.3 & 6.2 & 2.0 \\
\hline 3 & 3 & 134-833B-32R-1, $90-92$ & 376.7 & 13.15 & 4.73 & 9.57 & 6.63 & 1.94 & 0.68 & 2.14 & 2.08 & 1.18 & 1.31 & 0.24 & 3.6 & 2.0 \\
\hline 3 & 4 & $134-833 \mathrm{~B}-39 \mathrm{R}-1,86-88$ & 444.06 & 21.12 & 6.37 & 14.6 & 10.2 & 3.5 & 1.01 & 3.86 & 3.72 & 2.12 & 2.07 & 0.31 & 3.1 & 2.3 \\
\hline 3 & 5 & 134-833B-39R-3, 23-25 & 444.43 & 12.52 & 3.67 & 6.22 & 6.34 & 2.44 & 0.59 & 2.5 & 2.34 & 1.45 & 1.29 & 0.19 & 2.8 & 1.7 \\
\hline 3 & 6 & $134-833 \mathrm{~B}-47 \mathrm{R}-2,29-31$ & 501.79 & 13.14 & 4.02 & 8.93 & 7.78 & 2.79 & 0.73 & 3.41 & 2.45 & 1.72 & 1.33 & 0.23 & 3.0 & 2.2 \\
\hline 3 & 7 & $134-833 \mathrm{~B}-47 \mathrm{R}-4,130-132$ & 505.8 & 14.34 & 4.64 & 12.54 & 8.18 & 2.69 & 0.72 & 3.24 & 2.59 & 1.63 & 1.31 & 0.23 & 3.5 & 2.7 \\
\hline 3 & 8 & $134-833 \mathrm{~B}-47 \mathrm{R}-6,35-37$ & 507.85 & 14.18 & 3.5 & 10.19 & 8.37 & 2.66 & 0.81 & 3.34 & 2.77 & 1.86 & 1.56 & 0.27 & 2.2 & 2.9 \\
\hline 3 & 9 & $134-833 \mathrm{~B}-53 \mathrm{R}-1,23-25$ & 558.13 & 12.04 & 3.7 & 11.16 & 6.29 & 2.37 & 0.61 & 2.77 & 2.29 & 1.62 & 1.34 & 0.22 & 2.8 & 3.0 \\
\hline 3 & 10 & 134-833B-53R-1, 40-42 & 558.3 & 12.71 & 3.25 & 8.32 & 5.44 & 1.87 & 0.6 & 2.25 & 2.18 & 1.15 & 1.3 & 0.19 & 2.5 & 2.6 \\
\hline 3 & 11 & $134-833 \mathrm{~B}-53 \mathrm{R}-3,29-31$ & 561.19 & 13.98 & 3.43 & 10.13 & 6.43 & 2.16 & 0.63 & 2.23 & 2.55 & 1.45 & 1.41 & 0.21 & 2.4 & 3.0 \\
\hline 3 & 12 & $134-833 \mathrm{~B}-53 \mathrm{R}-6,15-17$ & 565.55 & 14.41 & 3.67 & 5.58 & 6.17 & 1.73 & 0.6 & 1.9 & 2.29 & 1.23 & 1.39 & 0.18 & 2.6 & 1.5 \\
\hline 3 & 13 & 134-833B-54R-5, 55-57 & 574.35 & 14.43 & 6.08 & 12.76 & 9.24 & 2.99 & 0.85 & 2.96 & 2.67 & 1.52 & 1.5 & 0.23 & 4.1 & 2.1 \\
\hline 3 & 14 & $134-833 \mathrm{~B}-54 \mathrm{R}-7,22-24$ & 577.02 & 14.52 & 4.79 & 10.69 & 7.93 & 2.53 & 0.71 & 2.91 & 2.63 & 1.36 & 1.43 & 0.2 & 3.3 & 2.2 \\
\hline 4 & 15 & $134-833 \mathrm{~B}-55 \mathrm{R}-5,65-67$ & 584.35 & 14.74 & 3.9 & 9.2 & 8.39 & 2.56 & 0.76 & 2.65 & 2.66 & 1.59 & 1.52 & 0.26 & 2.6 & 2.4 \\
\hline 4 & 16 & 134-833B-55R-6, 113-115 & 586.33 & 13.9 & 4.41 & 12.94 & 7.87 & 3.09 & 0.79 & 2.7 & 2.44 & 1.73 & 1.4 & 0.26 & 3.2 & 2.9 \\
\hline 4 & 17 & $134-833 B-65 R-1,138-140$ & 675.58 & 12.72 & 3.98 & 7.5 & 5.83 & 1.68 & 0.58 & 1.85 & 1.98 & 1.12 & 1.28 & 0.21 & 3.1 & 1.9 \\
\hline 4 & 18 & $134-833 \mathrm{~B}-65 \mathrm{R}-3,83-85$ & 678.03 & 21.07 & 8.94 & 16.77 & 11.36 & 3.48 & 1.04 & 3.36 & 3.59 & 1.89 & 2.0 & 0.31 & 4.5 & 1.9 \\
\hline 4 & 19 & $134-833 \mathrm{~B}-65 \mathrm{R}-4,134-136$ & 680.04 & 15.08 & 5.34 & 11.59 & 8.23 & 2.43 & 0.71 & 2.49 & 2.5 & 1.33 & 1.54 & 0.23 & 3.5 & 2.2 \\
\hline 4 & 20 & $134-833 \mathrm{~B}-65 \mathrm{R}-6,101-103$ & 682.71 & 10.37 & 4.65 & 11.95 & 6.77 & 2.64 & 0.62 & 2.74 & 2.12 & 1.51 & 1.29 & 0.22 & 3.6 & 2.6 \\
\hline 4 & 21 & $134-833 \mathrm{~B}-66 \mathrm{R}-3,4-6$ & 686.84 & 4.93 & 1.4 & 4.33 & 2.67 & 0.82 & 0.27 & 0.93 & 0.89 & 0.61 & 0.55 & 0.08 & 2.5 & 3.1 \\
\hline 4 & 22 & $134-833 \mathrm{~B}-66 \mathrm{R}-4,41-43$ & 688.71 & 16.01 & 5,48 & 11.66 & 8.58 & 2.76 & 0.76 & 3.03 & 2.69 & 1.72 & 1,6 & 0.26 & 3.4 & 2.1 \\
\hline 4 & 23 & $134-833 \mathrm{~B}-71 \mathrm{R}-1,64-66$ & 732.84 & 14.04 & 4.84 & 14.53 & 8.94 & 3.75 & 0.88 & 4.05 & 2.73 & 1.99 & 1.51 & 0.26 & 3.2 & 3.0 \\
\hline 4 & 24 & $134-833 \mathrm{~B}-71 \mathrm{R}-2,49-51$ & 734.19 & 17.95 & 7.59 & 17.11 & 11.68 & 4.26 & 0.9 & 4.01 & 3.14 & 2.15 & 1.82 & 0.31 & 4.4 & 2.3 \\
\hline 4 & 25 & $-78 R-2,12-1$ & 800.62 & 10.21 & 4.01 & 7.1 & 5.18 & 1.45 & 0.46 & 2.13 & 1.52 & 1.12 & 0.93 & 0.19 & 4.3 & 1.8 \\
\hline 4 & 26 & $134-833 \mathrm{~B}-78 \mathrm{R}-4,27-29$ & 803.77 & 12.72 & 3.45 & 7.09 & 5.42 & 1.63 & 0.48 & 1.75 & 2.14 & 1.22 & 1.31 & 0.19 & 2.6 & 2.1 \\
\hline 4 & 27 & 134-833B-79R-1, $18-20$ & 808.88 & 14.46 & 5.97 & 10.96 & 9.02 & 2.53 & 0.66 & 2.69 & 2.28 & 1.42 & 1.33 & 0.21 & 4.5 & 1.8 \\
\hline 4 & 28 & 134-833B-79R-2, $103-105$ & 811.23 & 15.71 & 6.12 & 11.29 & 8.67 & 2.17 & 0.71 & 2.47 & 2.64 & 1.34 & 1.53 & 0.21 & 4.0 & 1.8 \\
\hline 4 & 29 & 134-833B-80R-5, 53-55 & 824.83 & 22.43 & 12.89 & 26.55 & 16.96 & 4.37 & 1.12 & 4.11 & 3.7 & 2.18 & 2.17 & 0.3 & 5.9 & 2.1 \\
\hline 4 & 30 & $134-833 \mathrm{~B}-8 \mid \mathrm{R}-2,18-20$ & 829.6 & 11.77 & 4.26 & 5.66 & 6.13 & 1.75 & 0.61 & 2.23 & 1.84 & 1.2 & 1.2 & 0.21 & 3.6 & 1.3 \\
\hline 5 & 31 & 134-833B-93R-3, 45-47 & 937.05 & 26.63 & 20.98 & 40.65 & 24.04 & 6.22 & 1.65 & 5.18 & 4.12 & 2.33 & 2.37 & 0.39 & 8.9 & 1.9 \\
\hline 5 & 32 & 134-833B-94R-2, 48-50 & 945.28 & 12.76 & 4.74 & 6.98 & 6.02 & 1.52 & 0.56 & 1.77 & 1.8 & 1.13 & 1.17 & 0.19 & 4.1 & 1.5 \\
\hline
\end{tabular}

Several important correlations can be noted from the above tabulation. One sees a positive correlation between primary volcanogenic indicator elements such as K, with total REEs at Site 833. At Site 832, positive correlation between primary volcanogenic indicator elements such as $\mathrm{K}$, with LREEs only. We have used $\mathrm{MgO}$ content to look more closely at the distribution of REEs (Table 12). Using correlation coefficient, we focused on the distribution of REEs versus $\mathrm{K}_{2} \mathrm{O}, \mathrm{TiO}_{2}$, and $\mathrm{P}_{2} \mathrm{O}_{5}$. Samples showing $\mathrm{MgO}>5 \mathrm{wt} \%$ have positive correlation with LREEs that appears to be related to $\mathrm{TiO}_{2}$ and $\mathrm{P}_{2} \mathrm{O}_{5}$ Samples showing $\mathrm{MgO}<5 \mathrm{wt} \%$ have positive correlation with total REEs that are related to $\mathrm{K}_{2} \mathrm{O}$. These samples showing $\mathrm{MgO}<5 \mathrm{wt} \%$ have also positive correlation of LREEs that appears to follow $\mathrm{P}_{2} \mathrm{O}_{5}$. (REEs are discussed in more detail in the next section.)

$\mathrm{P}$ distribution at both Sites 832 and 833 is interesting. No correlation exist with $\mathrm{Ca} . \mathrm{P}$ is positively correlated with total REEs and $\mathrm{Pb}$. At Site $833, \mathrm{P}$ is also positively correlated with $\mathrm{Ba}, \mathrm{Cu}$, and $\mathrm{Zn}$. The distribution of $\mathrm{P}$ is probably reflecting an hydrothermal origin rather than a biogenic one, with possible Ba phosphate occurrence.

The significance of correlations between major oxides and REEs becomes apparent when one considers the distribution of the various elements between primary and authigenic phases, one of the important objectives of this study. Major elements incorporated into authigenic phases include $\mathrm{K}, \mathrm{Na}$, and $\mathrm{Ca}$ taken into the zeolites and $\mathrm{Mg}, \mathrm{Mn}$, and Fe taken into the clay minerals, such as the smectite and chlorite groups. Here we are looking for REE correlations, which may tell us something about low grade hydrothermal alteration of the volcanogenic sediments of North Aoba Basin. Combined with mineralogical evidence, we can make some simple observations. Site 832 and 833 have different geochemical and mineralogical signals. At Site 832 , where $\mathrm{Mg}$ is negatively correlated with HREEs, Na is positively correlated with HREEs, and $\mathrm{K}$ is positively correlated with total REEs, we may be able to differentiate between primary chemical signals and the altered chemical over- 

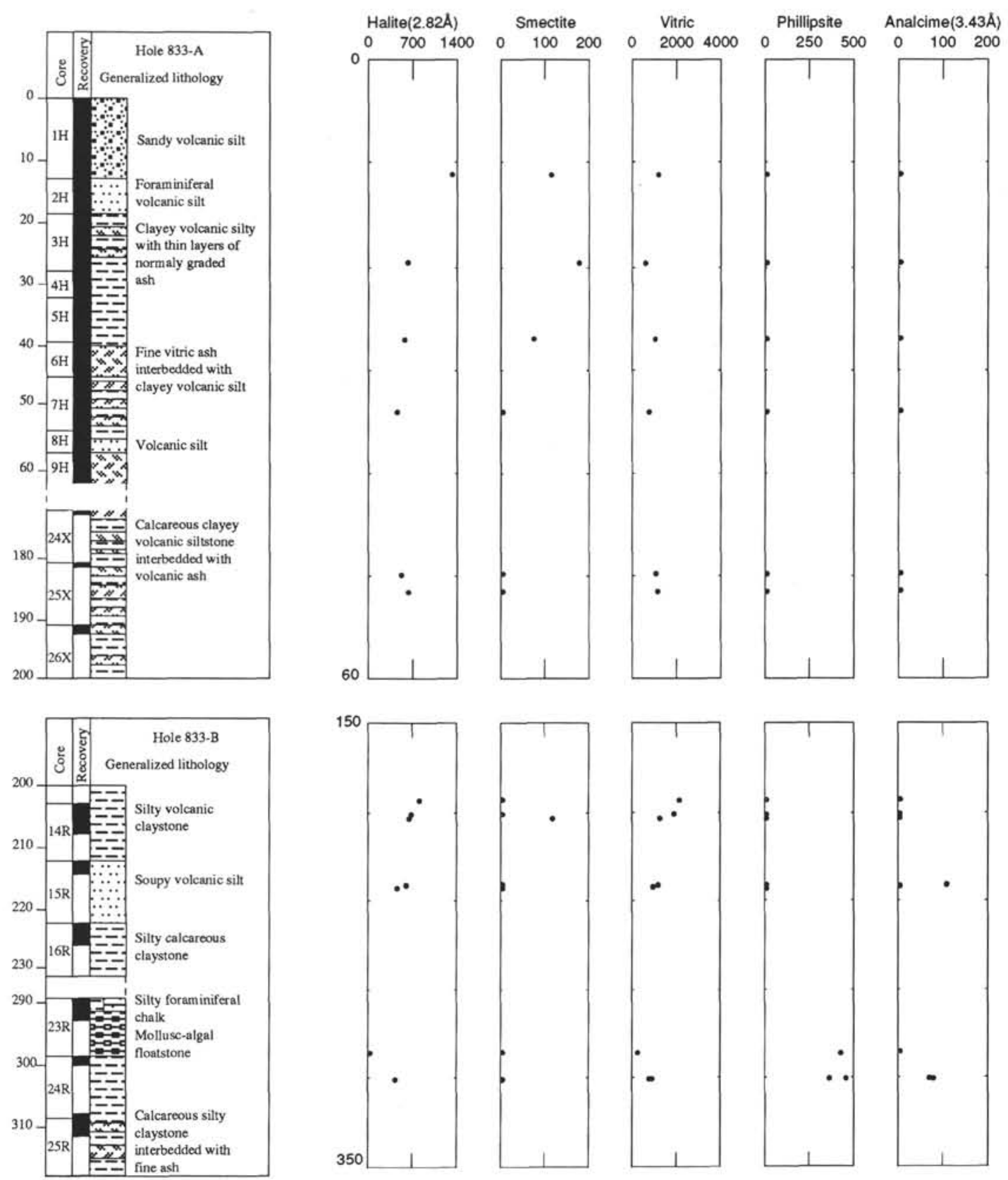

Figure 10. Mineralogical logs of the major mineralogical phases, associated with lithostratigraphic column, Site 833. Logs vs. depth are a semiquantitative representation (in arbitrary units:counts). The semiquantitative data are relative to evolution of each mineral phase, with the depth. But the abundance content of two different phases are not numerically comparable. This representation gives global trends of the evolution of the different phases.

print. Positive correlation between $\mathrm{K}$ and total REEs suggests that these geochemical signals are derived from unaltered primary volcanogenic components. Fractionation of HREEs correlated with $\mathrm{Mg}$ and $\mathrm{Na}$ suggests that these signals are associated with the alteration overprint.

$\mathrm{La} / \mathrm{Yb}$ is a parameter that indicates fractionation of LREEs over HREEs. Ce can be in the $3+$ or $4+$ oxidation state while La remains $3+$ regardless of redox conditions. $\mathrm{Ce} / \mathrm{La}$ can be used as an indication of redox conditions. Thus, the $\mathrm{La} / \mathrm{Yb}$ ratio versus $\mathrm{Ce} / \mathrm{La}$ ratio can be used to characterize typical marine materials (Jarvis, 1985; Kunzendorf, 1988; Van der Flier-Keller, 1991). Most of the samples from Sites 832 and 833 fall within the region of altered marine basalts (see Fig. 19 next section).
North Aoba Basin bulk sediment Fe and Mn is influenced by normal diagenesis and by the conditions of alteration observed in coarse grained authigenic mineral host units. Highest values of Mn are associated with highest values of Fe at both sites. At Site 833, the near surface sediments, with high concentrations of $\mathrm{Mn}$ and $\mathrm{Fe}$ show opaque Mn-Fe micro-nodules. For example, Sample 134-833A-3H$1,84-86 \mathrm{~cm}, 19.84 \mathrm{mbsf}$, displays $\mathrm{MnO}$ values of $0.19 \%$ and $\mathrm{Fe}_{2} \mathrm{O}_{3}$ values of 11.73. Surficial detrital smectites occur in these shallow intervals, at both sites, that do not have (or if so, rare) zeolite minerals (Tables 1 and 5). In contrast, at Site 832, high values of $\mathrm{Mn}$ and $\mathrm{Fe}$ (for example Sample 134-832B-89R-3, 105-106 cm, at $994.85 \mathrm{mbsf}$, $\mathrm{MnO}=0.19 \mathrm{wt} \%$, total $\mathrm{Fe}=10.64 \mathrm{wt} \%$ ) are associated with a com- 
Quartz(3.34A) Calcite(3.04A) Plagioclase(3.21A) Pyroxene(2.99A)

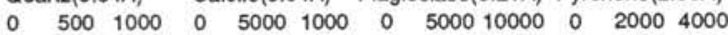
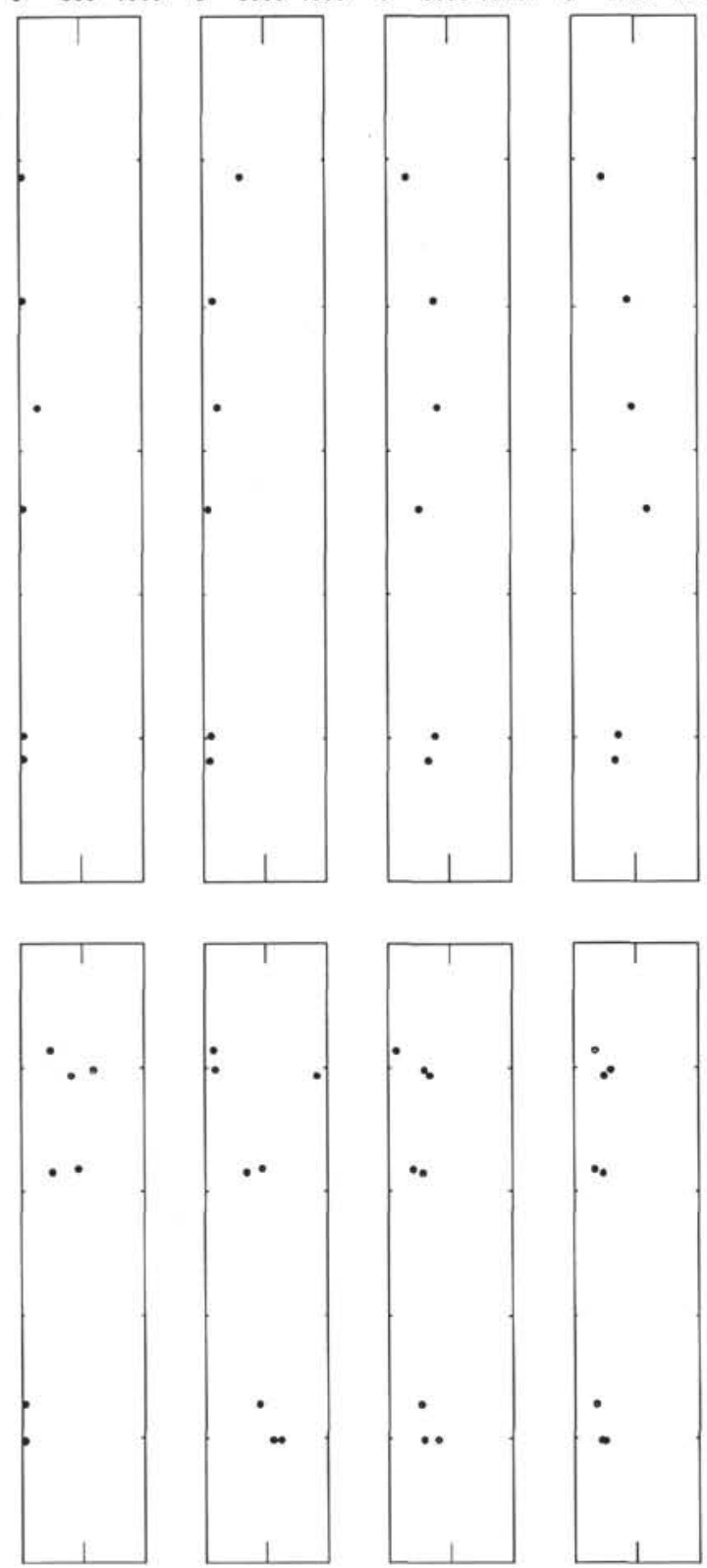

Figure 10 (continued).

plex authigenic assemblage; zeolites (phillipsite, analcime, chabazite, heulandite, and erionite) and smectites. This sample is a dark unconsolidated silty sandstone, one of the most altered intervals.

\section{Normalization to Arc Tholeiites}

REE normalization diagrams are routinely used as a device for relating measured REE values in samples under investigation to well characterized rocks whose geochemical history has already been determined. Figure 16A gives REE from selected samples from Sites 832 and 833 normalized to the unaltered Central New Hebrides Island (CNHI) arc tholeiite of Monjaret (1989). In general, shallower sediments show REE enrichments (up to three times CNHI values). Deeper sediments are relatively depleted in REEs and show selective depletion of LREEs over HREEs. For example, Sample 134-832B-36R-1, $108-110 \mathrm{~cm}, 481 \mathrm{mbsf}$, contains the highest REE concentrations
Table 10. C, $\mathrm{N}$ analysis results (with $\mathrm{CHN}$ ).

\begin{tabular}{|c|c|c|c|c|c|c|c|c|}
\hline Sample 134- $(\mathrm{cm})$ & $N$ & $\begin{array}{l}\text { Depth } \\
\text { (mbsf) }\end{array}$ & $\begin{array}{c}\text { C } \\
\text { (\%) }\end{array}$ & $\mathrm{MgO}$ & $\mathrm{CaO}$ & LOI & $\mathrm{CO}_{2}$ & $\mathrm{H}_{2} \mathrm{O}^{+}$ \\
\hline $\begin{array}{l}832 \mathrm{~A}- \\
19 \mathrm{H}-1,85-87\end{array}$ & 2 & 141.85 & 0.523 & 2.31 & 6.09 & 5.47 & 1.92 & 3.55 \\
\hline \multicolumn{9}{|l|}{$832 \mathrm{~B}$ - } \\
\hline $23 \mathrm{R}-3,42-44$ & 3 & 360.02 & 1.956 & 4.32 & 13.76 & 13.12 & 7.17 & 5.95 \\
\hline $36 \mathrm{R}-1,108-110$ & 4 & 481.88 & 1.043 & 2.50 & 9.19 & 7.63 & 3.82 & 3.81 \\
\hline $39 \mathrm{R}-2,91-93$ & 5 & 512.21 & 3.185 & 2.91 & 20.06 & 17.67 & 11.68 & 5.99 \\
\hline $40 R-2,23-25$ & 6 & 521.23 & 3.405 & 4.24 & 19.28 & 16.32 & 12.49 & 3.84 \\
\hline SIR-1, 26-28 & 7 & 625.96 & 0.135 & 7.63 & 9.28 & 12.00 & 0.50 & 11.51 \\
\hline $52 \mathrm{R}-1,35-37$ & 8 & 635.65 & 0.218 & 8.75 & 11.5 & 10.49 & 0.80 & 9.69 \\
\hline $52 \mathrm{R}-1,115-117$ & 9 & 636.45 & 0,106 & 5.66 & 9.28 & 13.26 & 0.39 & 12.87 \\
\hline $52 \mathrm{R}-3,25-27$ & 10 & 638.61 & 0.138 & 8.53 & 9.41 & 9.94 & 0.51 & 9.43 \\
\hline $83 R-3,69-71$ & 11 & 936.99 & 0.457 & 7.10 & 7.69 & 12.90 & 1.68 & 11.22 \\
\hline $84 \mathrm{R}-1,14-16$ & 12 & 943.04 & 0.188 & 2.77 & 4.00 & 11.39 & 0.69 & 10.70 \\
\hline $85 R-4,17-19$ & 13 & 957.27 & 1.050 & 2.50 & 7.44 & 17.31 & 3.85 & 13.46 \\
\hline $86 R \cdot 2,71-73$ & 14 & 977.91 & 0.411 & 7.05 & 8.10 & 11.70 & 1.51 & 10.19 \\
\hline $89 \mathrm{R}-3,105-107$ & 15 & 994.85 & 0.567 & 3.89 & 6.91 & 12.03 & 2.08 & 9.95 \\
\hline $94 \mathrm{R}-2,102-103$ & 16 & 1041.52 & 1.862 & 10.75 & 5.66 & 16.72 & 6.83 & 9.89 \\
\hline $99 \mathrm{R}-1,43-45$ & 17 & 1087.73 & 0.325 & 5.87 & 4.66 & 21.46 & 1.19 & 20.27 \\
\hline $100 R-4,42-44$ & 18 & 1101.92 & 0.221 & 6.44 & 7.94 & 8.15 & 0.81 & 7.34 \\
\hline \multicolumn{9}{|l|}{$833 \mathrm{~A}-$} \\
\hline $3 \mathrm{H}-1,84-86$ & 1 & 19.84 & 0.137 & 4.83 & 10.00 & 5.04 & 0.50 & 4.54 \\
\hline $13 R-1,33-35$ & 2 & 193.43 & 2.499 & 2.91 & 16.46 & 13.76 & 9.16 & 4.60 \\
\hline $39 \mathrm{R}-\mathrm{I}, 86-88$ & 4 & 444.06 & 0.795 & 5.51 & 7.00 & 12.82 & 2.92 & 9.91 \\
\hline $39 \mathrm{R}-3,23-25$ & 5 & 444.43 & 0.230 & 8.00 & 9.05 & 9.71 & 0.84 & 8.87 \\
\hline $47 R-2,29-31$ & 6 & 501.79 & 0.275 & 8.91 & 11.33 & 8.57 & 1.01 & 7.56 \\
\hline $47 R-4,130-132$ & 7 & 505.80 & 0.269 & 8.16 & 10.49 & 7.77 & 0.99 & 6.78 \\
\hline $47 \mathrm{R}-6,35-37$ & 8 & 507.85 & 0.371 & 5.82 & 9.80 & 7.60 & 1.36 & 6.24 \\
\hline $53 \mathrm{R}-1,23-25$ & 9 & 558.13 & 0.195 & 7.25 & 9.71 & 11.92 & 0.72 & 11.21 \\
\hline $53 \mathrm{R}-1,40-42$ & 10 & 558.30 & 0.371 & 7.30 & 9.71 & 12.84 & 1.36 & 11.48 \\
\hline $53 R-3,29-31$ & 11 & 561.19 & 0.335 & 8.73 & 9.69 & 10.42 & 1.23 & 9.19 \\
\hline $53 R-6,15-17$ & 12 & 565.55 & 0.861 & 6.78 & 10.30 & 11.65 & 3.16 & 8.49 \\
\hline 54R-7, 22-24 & 14 & 577.02 & 0.272 & 7.69 & 9.60 & 10.23 & 1.00 & 9.23 \\
\hline $55 R-6,113-115$ & 16 & 586.33 & 0.307 & 6.58 & 10.58 & 11.86 & 1.13 & 10.73 \\
\hline $65 \mathrm{R}-1,138-140$ & 17 & 675.58 & 1.604 & 4.00 & 10.80 & 17.95 & 5.88 & 12.07 \\
\hline $65 \mathrm{R}-3,83-85$ & 18 & 678.03 & 0.801 & 5.41 & 9.46 & 12.77 & 2.94 & 9.83 \\
\hline $65 R-4,134-136$ & 19 & 680.04 & 0.729 & 4.89 & 11.23 & 13.25 & 2.67 & 10.58 \\
\hline $65 \mathrm{R}-6,101-103$ & 20 & 682.71 & 1.071 & 4.51 & 9.25 & 15.94 & 3.93 & 12.01 \\
\hline $66 \mathrm{R}-3,4-6$ & 21 & 686.84 & 0.252 & 5.79 & 9.38 & 12.78 & 0.92 & 11.86 \\
\hline $66 \mathrm{R}-4,41-43$ & 22 & 688.71 & 0.919 & 6.29 & 8.33 & 15.22 & 3.37 & 11.85 \\
\hline 71R-1, 64-66 & 23 & 732.84 & 0.417 & 6.19 & 9.85 & 10.33 & 1.53 & 8.80 \\
\hline $71 \mathrm{R}-2,49-51$ & 24 & 734.19 & 3.480 & 3.59 & 17.63 & 20.87 & 12,76 & 8.11 \\
\hline $78 R-4,27-29$ & 26 & 803.77 & 3.107 & 6.24 & 8.39 & 17.24 & 11.39 & 5,85 \\
\hline $79 \mathrm{R}-2,103-105$ & 28 & 811.83 & 2.915 & 3.58 & 14.91 & 18.74 & 10.69 & 8.05 \\
\hline $80 \mathrm{R}-5,53-55$ & 29 & 824.83 & 1.912 & 2.66 & 10.48 & 20.79 & 7.01 & 13.78 \\
\hline $81 R-2,18-20$ & 30 & 829,68 & 3.676 & 1.85 & 18.66 & 19.45 & 13.48 & 5.97 \\
\hline
\end{tabular}

Notes: $\mathrm{MgO}, \mathrm{CaO}$ analysis results (with ICP. Induced Coupled $\mathrm{Plasma}$ ). $\mathrm{CO}_{2}$ is calculated from $\mathrm{C}$ data. $\mathrm{H}_{2} \mathrm{O}^{+}$represents the differnce between $\mathrm{LOI}$ and $\mathrm{CO}_{2}$.

observed at this site. This interval is characterized by clay-size volcanic siltstone with abundant biogenic carbonate (foraminifers). XRD analyses does not record the presence of authigenic minerals, such as zeolites or clay minerals. $\mathrm{SiO}_{2}$ content is over $50.21 \mathrm{wt} \%$. In contrast, the interval showing the lowest concentrations of REEs is Sample 134-832B94R-2, 102-104 cm, $1041.52 \mathrm{mbsf}$. XRD data show smectite and zeolite occurrences (phillipsite, analcime, chabazite) and no occurrence of calcite. $\mathrm{SiO}_{2}$ content is $45.34 \%$. This interval displays the highest content of $\mathrm{MgO}$ at Site 832. Mineralogical content of this sample is also characterized by dolomite and magnesite.

The greatest depletion of LREEs is noticed at Sample 134-832B$89 \mathrm{R}-3,105-106 \mathrm{~cm}, 995.85 \mathrm{mbsf}$. This sample is an unconsolidated silty sandstone. This interval showing a strong REE fractionation, displays the highest content of $\mathrm{Fe}_{2} \mathrm{O}_{3}(10.64 \mathrm{wt} \%)$ and $\mathrm{MnO}(0.19$ wt\%). XRD analyses record the highest occurrence of erionite in Site 832 , with high chabazite content. Phillipsite, analcime, and chabazite are the other major zeolitic phases. Heulandite is noticeable.

Many of Site 832 samples have REE abundances very close to those of CNHI arc tholeiite. This suggests that these sediments retain a REE signature that is close to representative of their original magmatic signature. However, those samples with REE signatures (depletion) very different from $\mathrm{CNHI}$ arc tholeiite have altered (smectites, zeolites). REE are mobilized by the alteration processes, which have promoted zeolitization of the deeper sediments in this region. An Eu negative anomaly is observed, probably related to redox condition.

Site 833 (Fig. 16B) shows similar trends to those observed at Site 832 , though some of the trends are more exaggerated at Site 833: enrichment of LREE in surficial samples, close geochemical composition to arc tholeiite with Eu negative anomaly, irregular Ce negative anomaly. Sample 833B-66R-3,4-6 cm, is singular: very depleted 


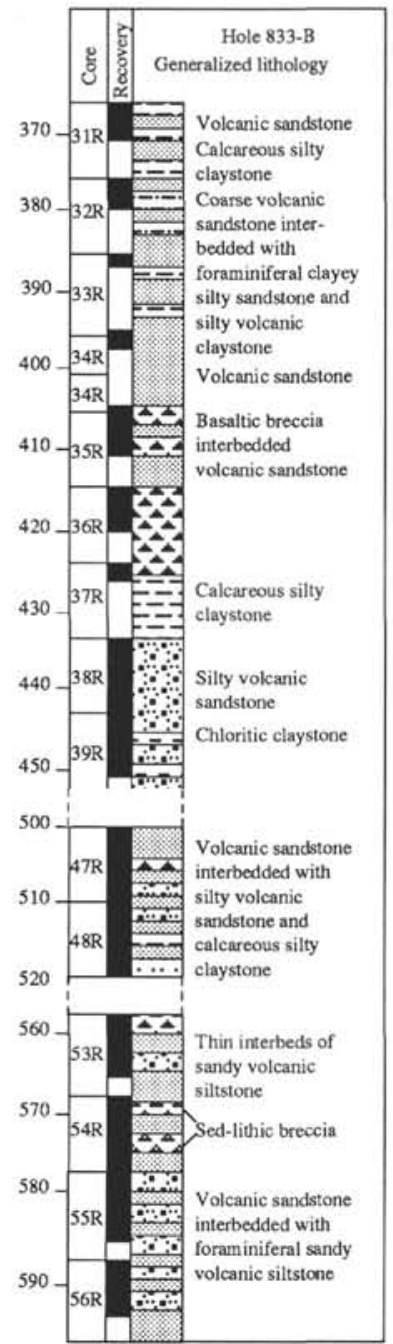

Figure 10 (continued).
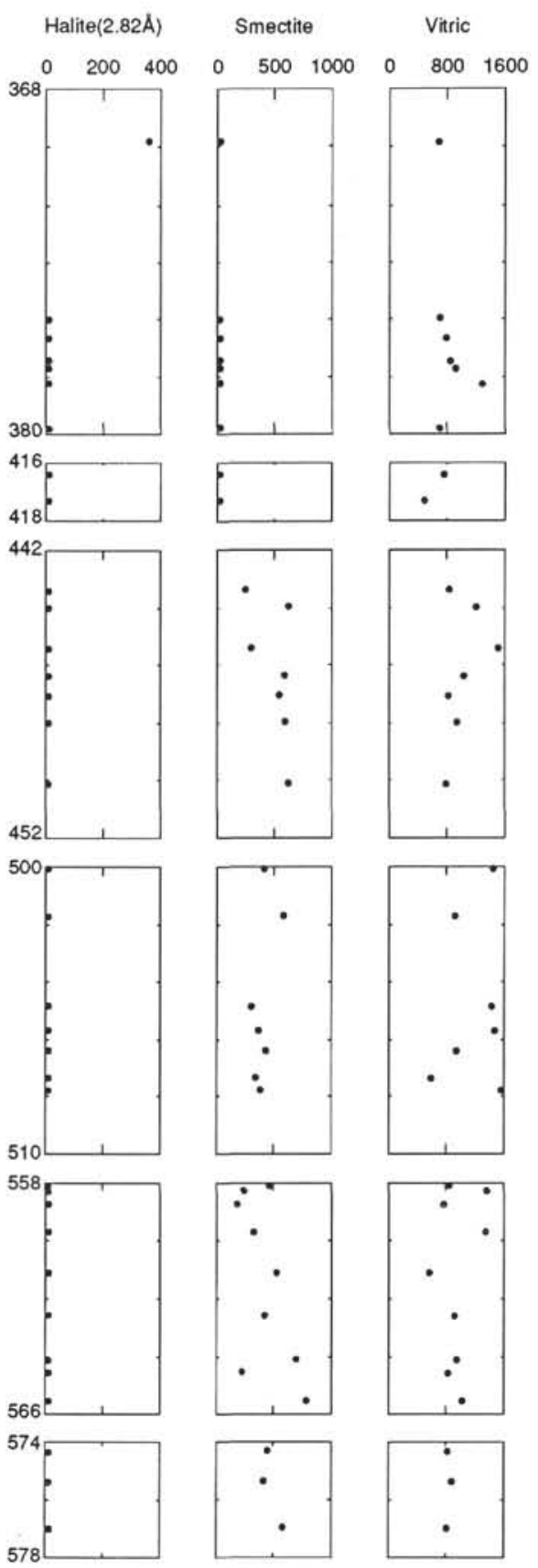

Phillipsite

Analcime $(3.43 \AA)$

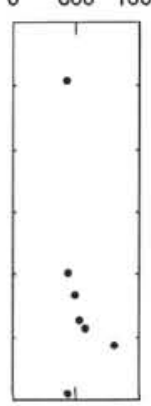

$0 \quad 10002000$
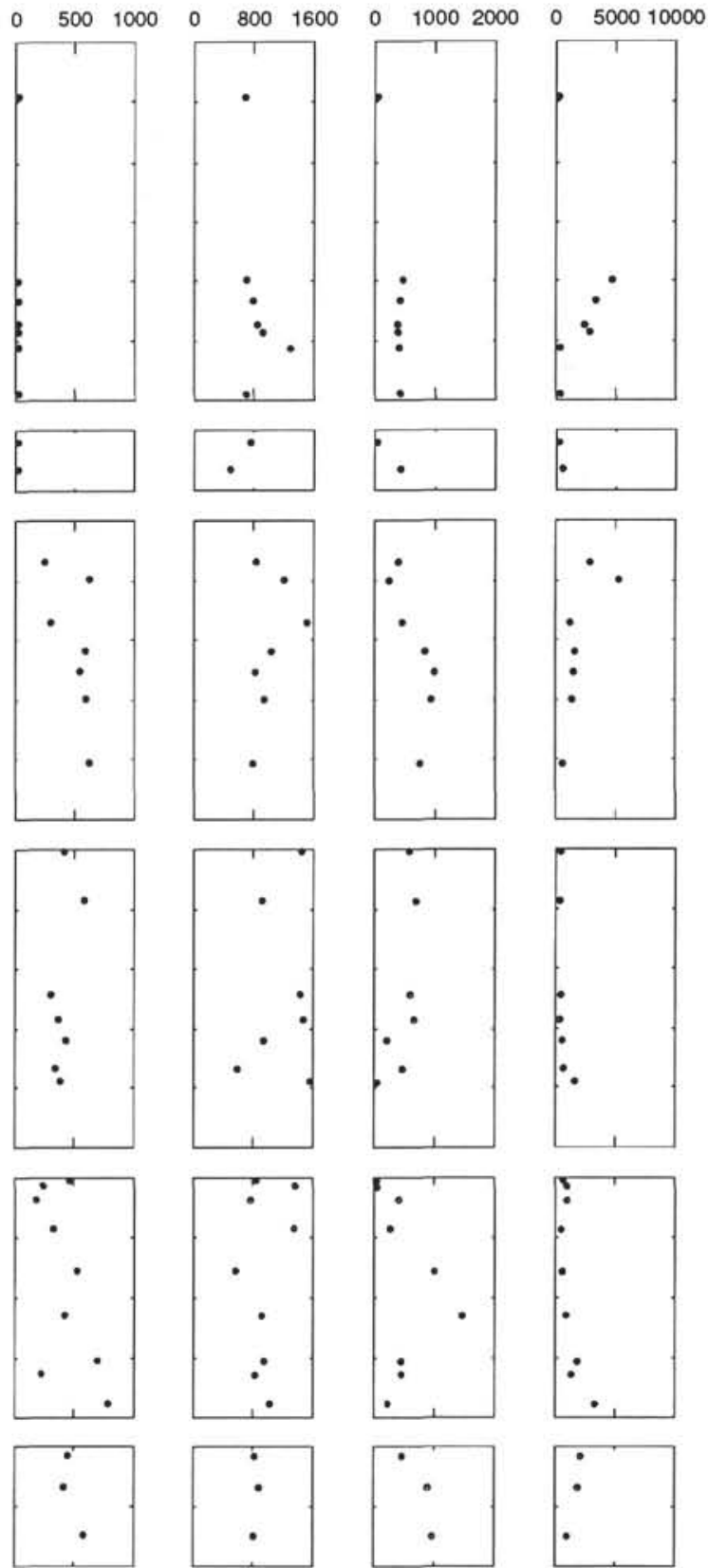

in REE, especially in La, and Eu. This sample is strongly enriched with authigenic minerals (phillipsite, analcime, chabazite, thomsonite, and smectite).

\section{REE Normalization to North American Shale Composite}

Figures 17A and B show selected REE abundances for Sites 832 and 833 relative to North American Shale Composite (NASC) (Gromet et al., 1984). NASC is a standard reference rock considered to be representative of average continental crust. When compared to NASC, sediments from North Aoba Basin are relatively depleted in REEs and significantly more depleted in LREEs than HREEs. In general, REE depletions observed at both sites are greater in deeper sediments than in surficial sediments. A moderate positive Eu anomaly may be attributed to volcanic feldspars (Cullers and Graf, 1984) and may be con- sidered further evidence of the unaltered character of some of the original volcanogenic components. A noticeable $\mathrm{Ce}$ anomaly is observed in sediments from Site 833, but this Ce anomaly is unusually weak, for the southwestern Pacific. Other Pacific and Indian oceans and Lau Basin spreading center ridges sediments generally have a stronger $\mathrm{Ce}$ anomaly (Henderson, 1984; Kunzendorf et al., 1988).

\section{Incompatible Element Normalization to MORB}

Figures $18 \mathrm{~A}$ and B show selected incompatible element abundances for Sites 832 and 833 relative to average mid ocean ridge basalt (MORB) (Sun and McDonough, 1989). The purpose of the MORB normalization diagrams is to compare Site 832 and 833 volcanogenic components to those of Santa Maria Island (SMI). Normalization to MORB of SMI volcanic rocks are given by Briqueu (1985). SMI 


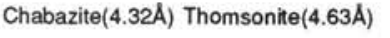

Heulandite
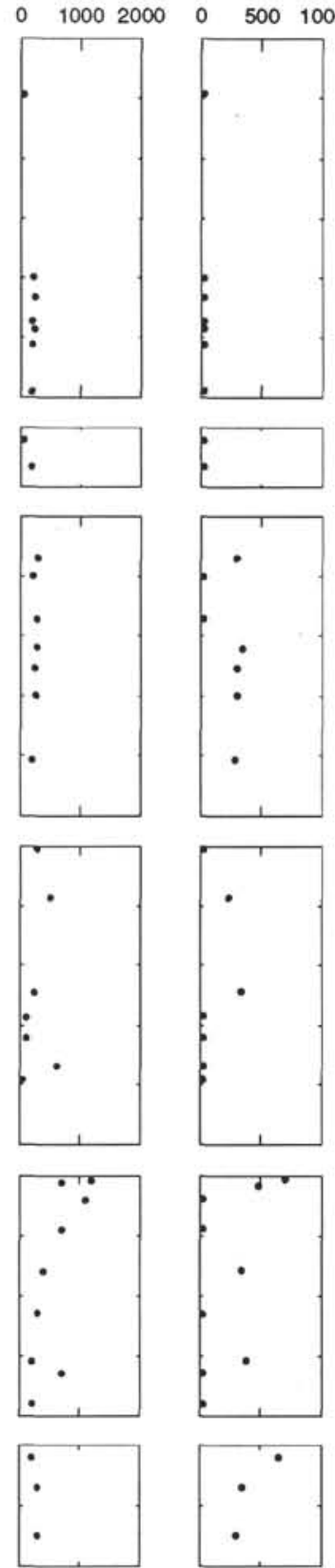

Figure 10 (continued).

volcanic emissions are characterized by enrichments in incompatible elements, up to 10 times that of MORB, with $\mathrm{Nb}$ depletion, positive $\mathrm{Ce}$ anomaly, and enrichment of $\mathrm{Sr}, \mathrm{K}, \mathrm{Rb}$ and $\mathrm{Ba}$ relative to $\mathrm{P}, \mathrm{Zr}, \mathrm{Ti}$, and $\mathrm{Y}$.

The relatively shallow sediments, compared to other ash levels and lavas (Collot, Greene, Stokking, et al., 1992), for example Sample 134-832A-2H-2, 6-8 cm, or Sample 134-832A-19H-1, 85-87 cm, composed of vitric ash, have an incompatible element pattern very similar to that of Santa Maria (or Aoba) volcanics, giving further evidence that these ashes are derived from Santa Maria eruptions, and they are typical of subduction zone volcanic rocks. Samples from greater depths below the sea floor show evidence of increased extent of alteration with increasing depth. But porosity is still the dominant factor. Deeper sediments have MORB-normalized patterns that are similar in shape to unaltered samples, but relative abundance of elements is lower.

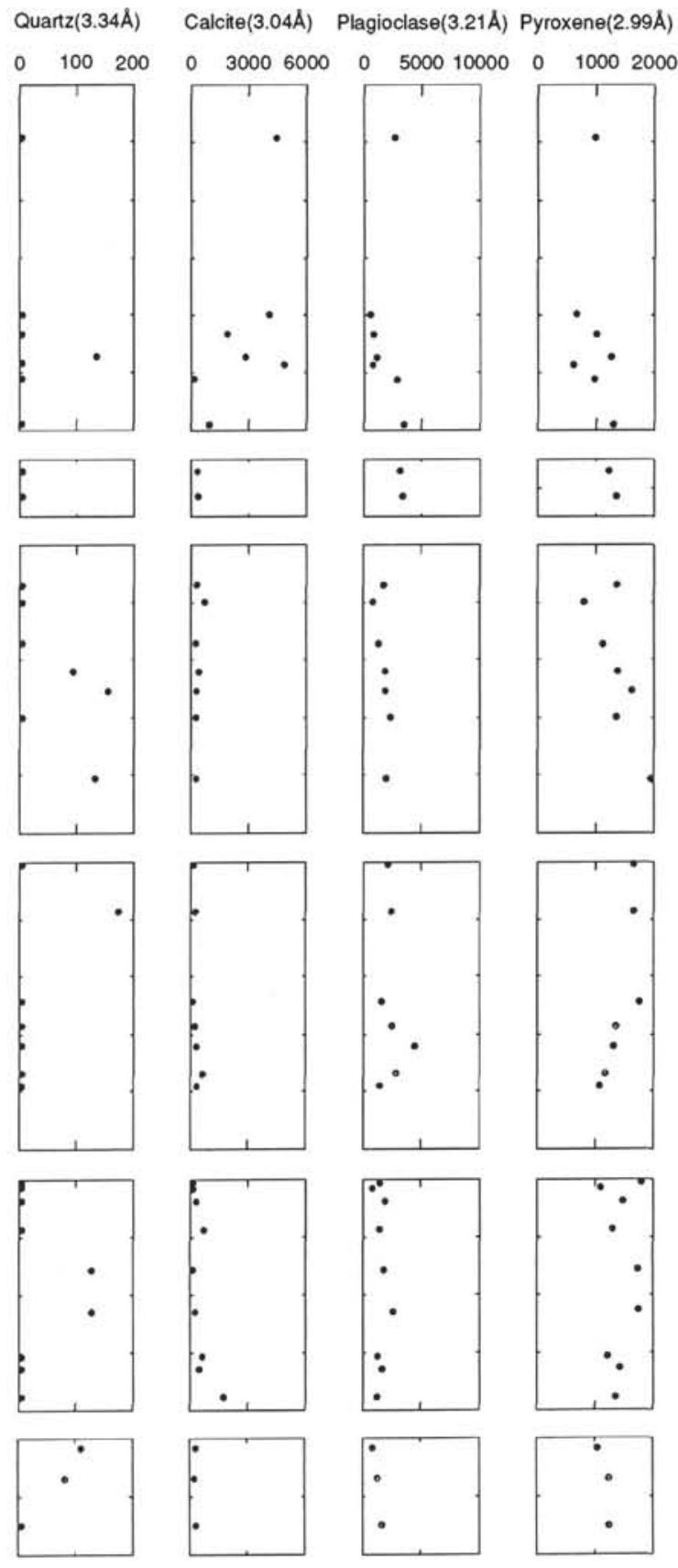

\section{SUMMARY AND CONCLUSION}

Mineralogy and geochemistry of volcanosedimentary deposits of the North Aoba Basin are controlled by two major factors: (1) volcanic emissions (either submarine or subaerial) from the surrounding New Hebrides Island Arc volcanoes; and (2) in-situ alteration of the primary components.

Volcanic emissions provide primary pyroclastic materials which accumulate as sediments in North Aoba Basin. The pyroclastic units include microbreccias, volcanic sandstones, siltstones, and claystones (ash levels, hyaloclastites) that are interbedded with the biogenic carbonate materials (foraminifers and nannofossils). In general, finegrained units (siltstones, claystones) are not extensively altered. Fine-grained units reflect the chemical and mineralogical characteristics of the magmatic source: calc-alkaline and low $\mathrm{K}$ series basalts and basaltic andesites (Figs. 14 and 15). The unaltered units are typical 


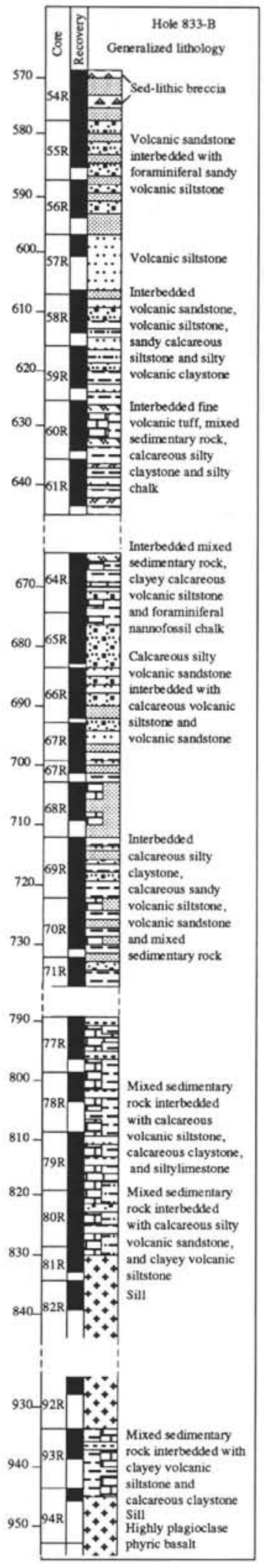

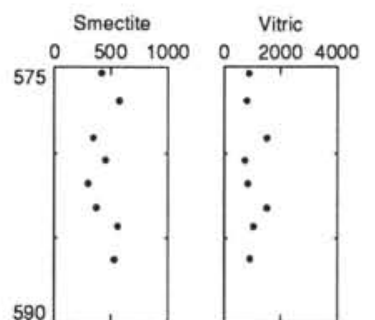

615
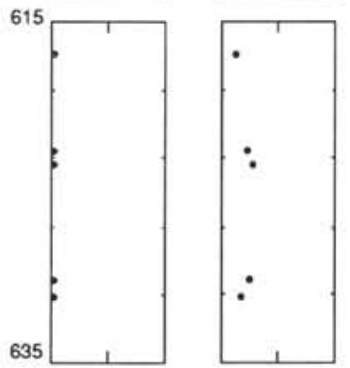

670
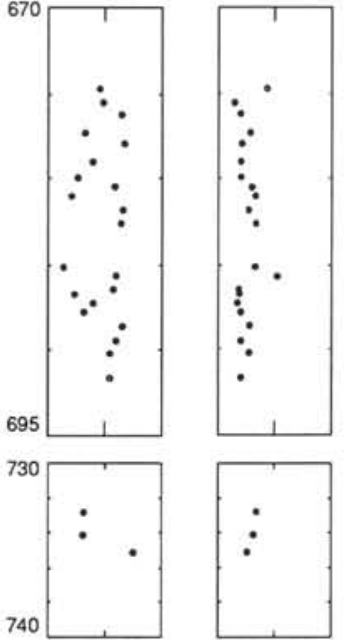

795
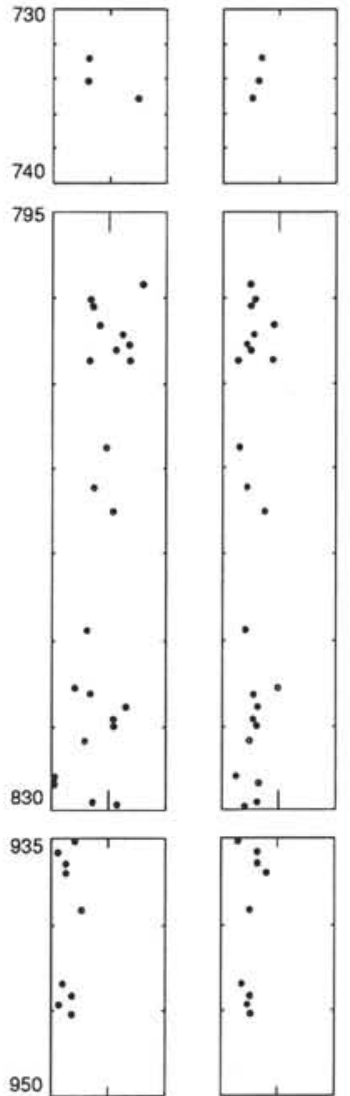

Phillipsite Analcime(3.43A) Chabazite(4.32A) Thomsonite(4.63A) r

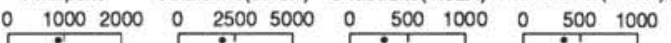
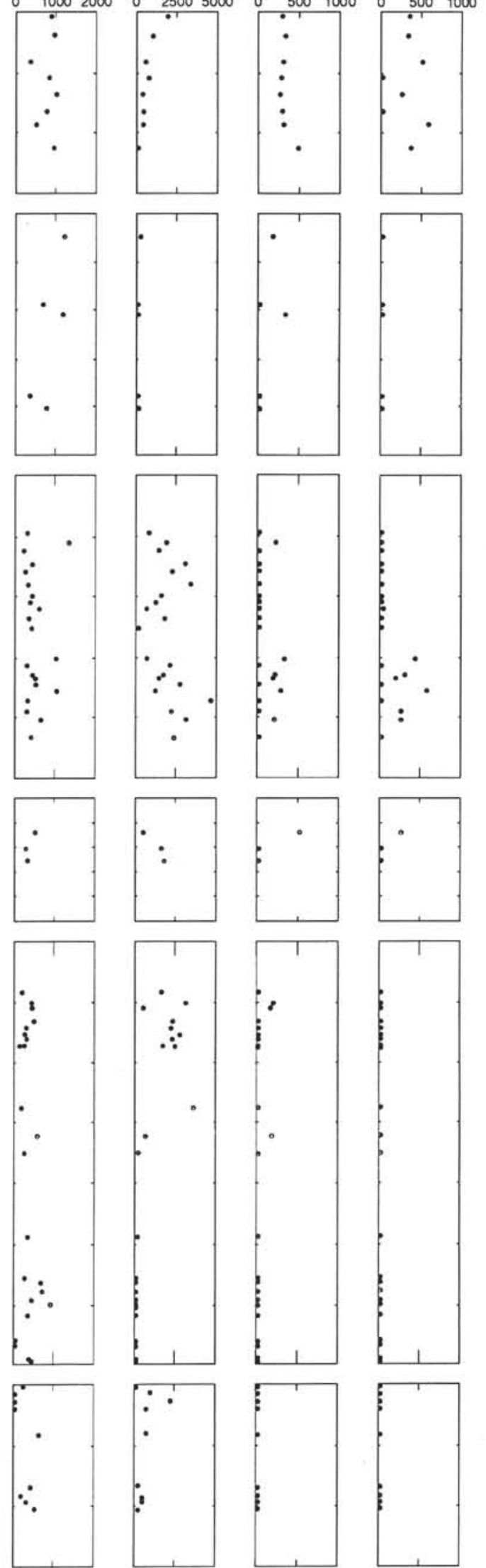

Figure 10 (continued). 


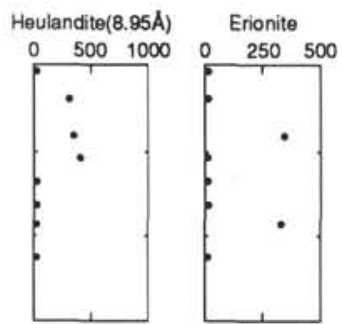

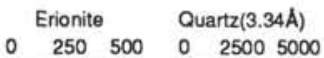

$\begin{array}{llllll}\text { Calcite(3.04A) Plagioclase(3.21A) } & \text { Pyroxene(2.99A) } \\ 0 \quad 700014000 & 0 & 500010000 & 0 & 1000 & 2000\end{array}$
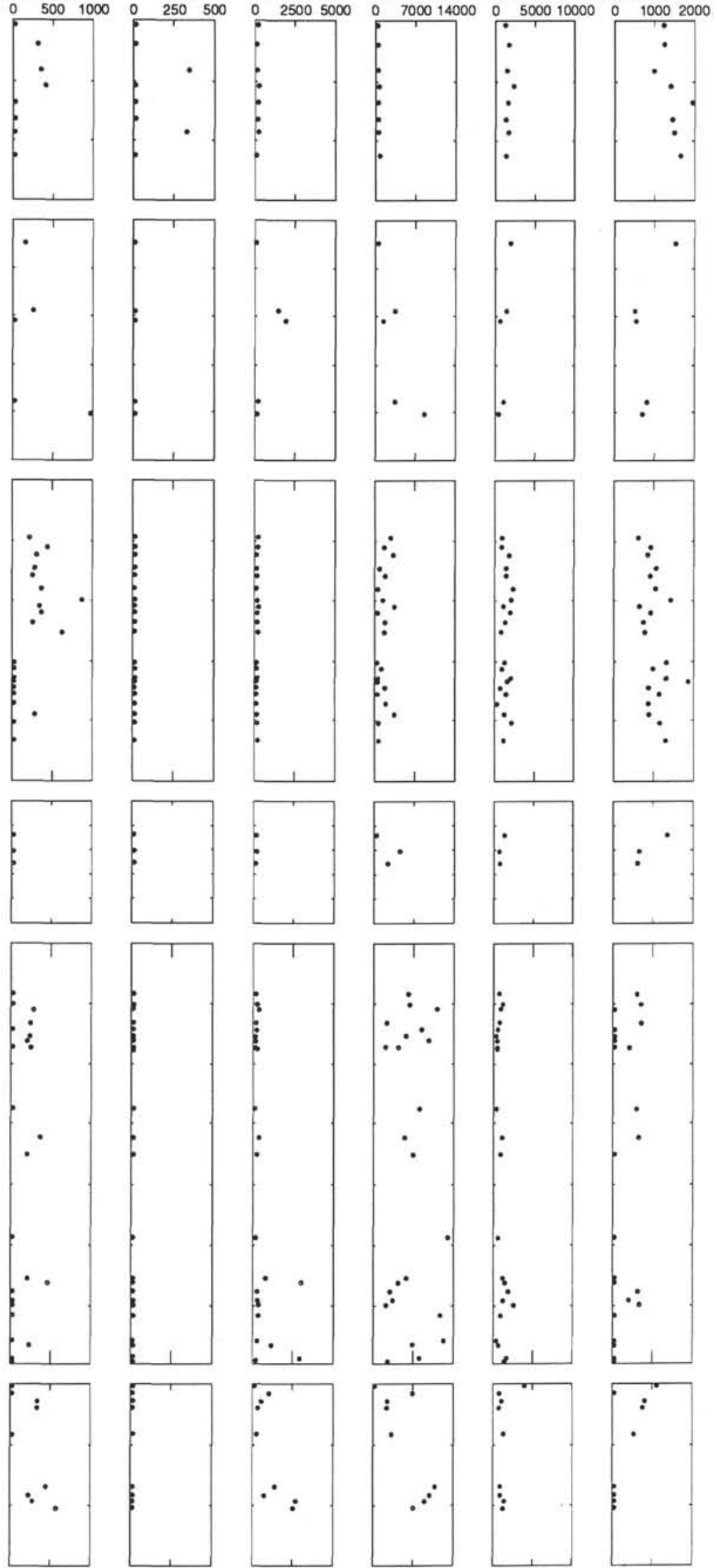

Figure 10 (continued). 

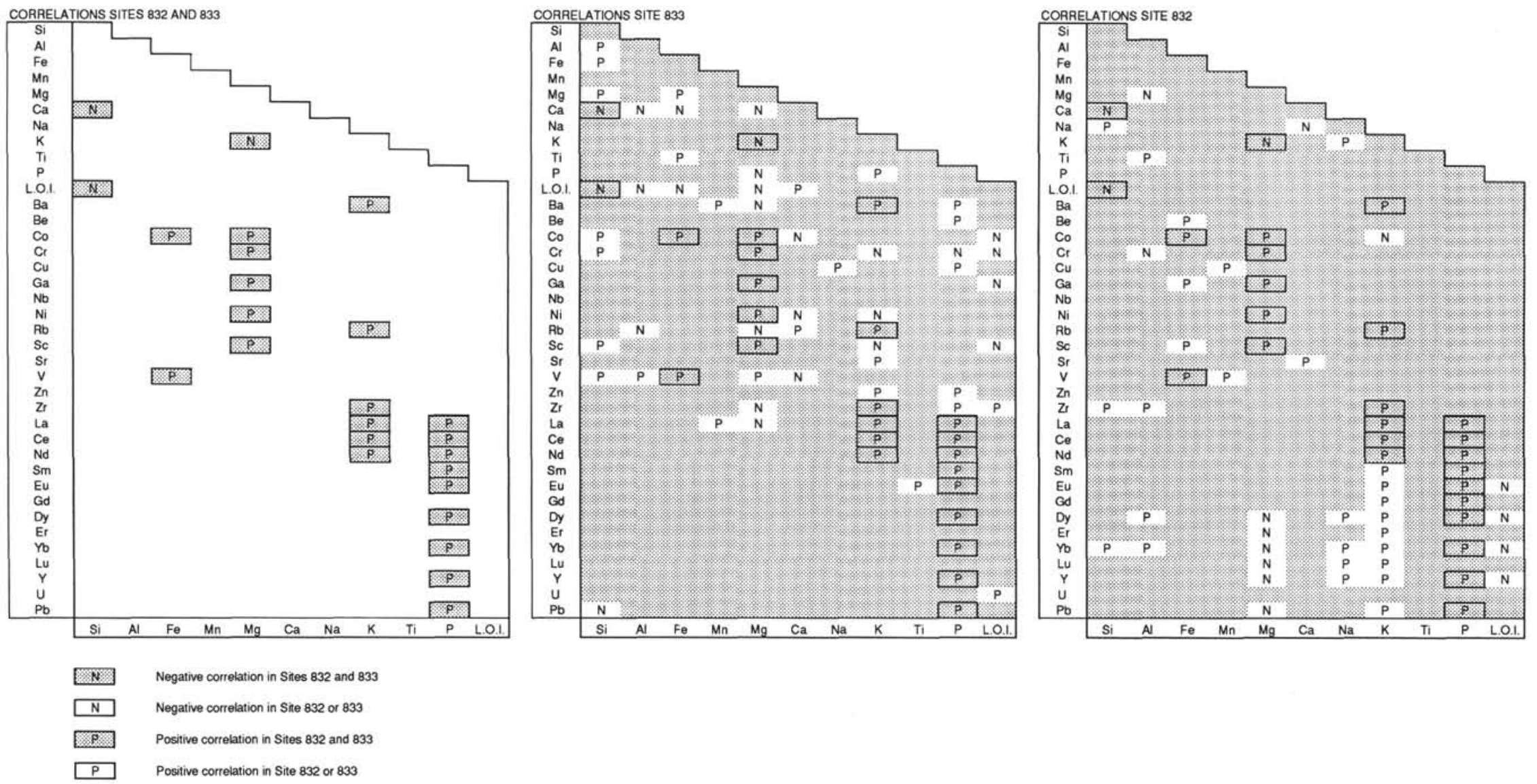

Figure 11. Elemental correlations for Sites 832 and 833 and global data from Sites 832 and 833. $P=$ positive, $N=$ negative. 


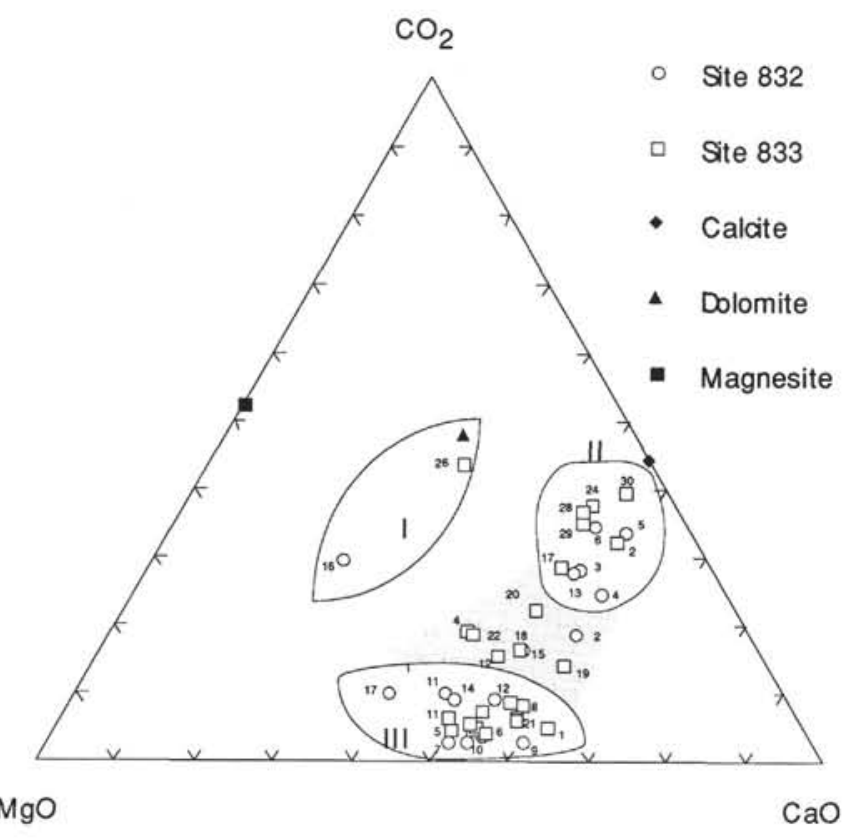

Figure 12. Ternary $\mathrm{CO}_{2}-\mathrm{MgO}-\mathrm{CaO}$ diagram. $\mathrm{MgO}$ and $\mathrm{CaO}$ from bulk analysis. Stoichiometric calcite, magnesite, and dolomite are plotted in the diagram. Notice the partition of carbonates related to these minerals. The numbers refer to major elements results of Tables 6 and 7.

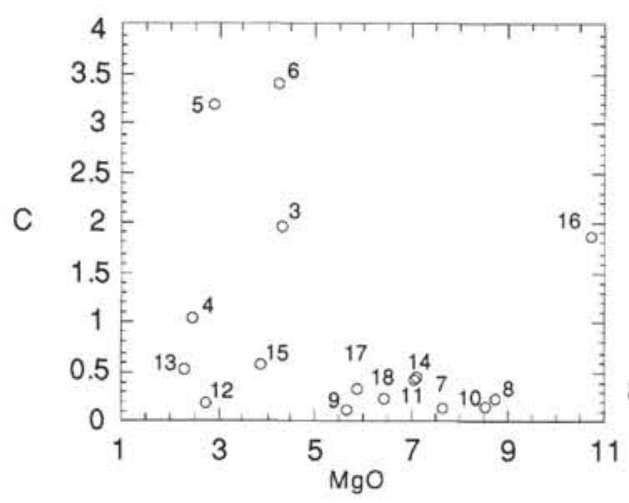

832

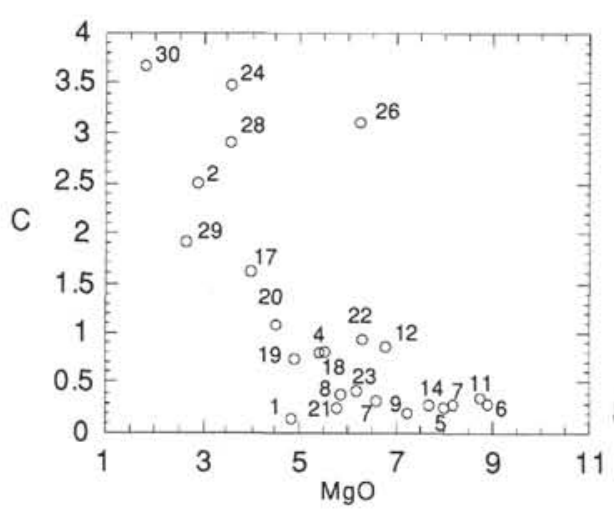

833

Figure 13. C-MgO diagrams (on samples from Sites 832 and 833). The numbers refer to major elements results of Tables 6 and 7. Notice the two populations: $<5 \%,>5 \%$; and the rich $\mathrm{MgO}$ sample that shows magnesite on XRD data.
832

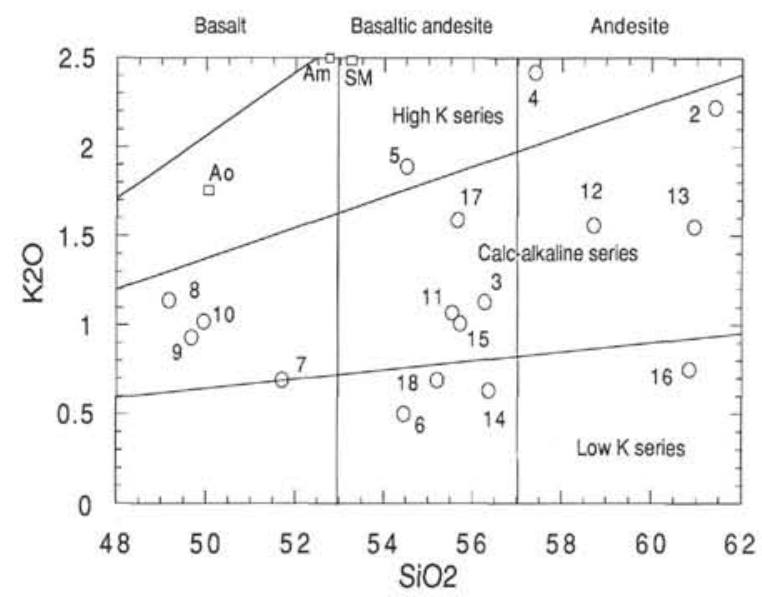

Figure 14. $\mathrm{K}_{2} \mathrm{O}-\mathrm{SiO}_{2}$ diagram on anhydrous and carbonate-free basis, Holes $832 \mathrm{~A}$ and $832 \mathrm{~B}$. The numbers refer to major elements results of Table 6.

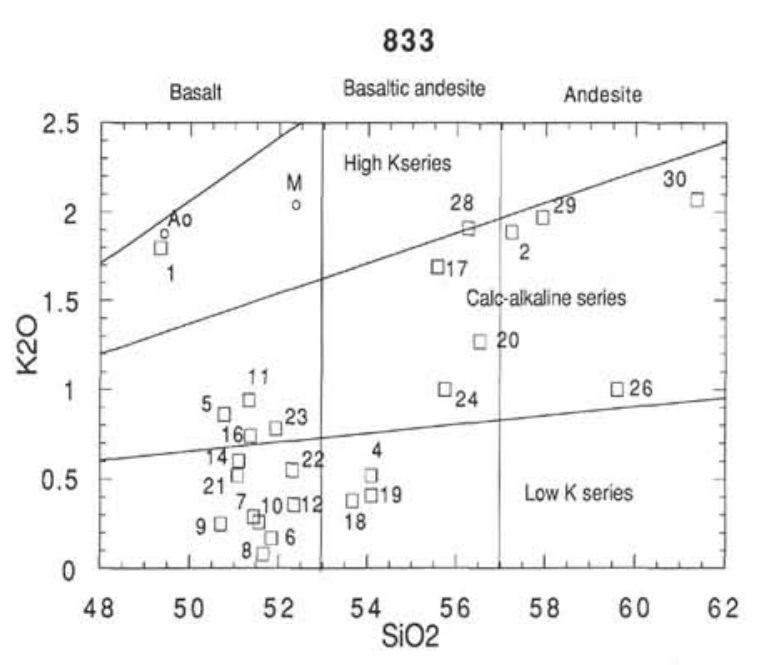

Figure $15 . \mathrm{K}_{2} \mathrm{O}-\mathrm{SiO}_{2}$ diagram on anhydrous and carbonate free basis, Holes $833 \mathrm{~A}$ and $833 \mathrm{~B}$. The numbers refer to major elements results of Table 7.

of subduction zone related volcanic arc materials from near by islands, such as Santa Maria or Aoba islands.

Superimposed on the primary volcanogenic and biogenic components accumulated in North Aoba Basin is a recognizable alteration overprint. The mineralogical and geochemical overprint has affected sediments through most of the sequence recovered during Leg 134, including relatively shallow Pleistocene units. The alteration overprint is observed primarily in more coarse-grained units (microbreccias and sandstones). Factors controlling volcaniclastic sandstone diagenesis in island arc basins are age of the deposits, composition, heat flow from the basement, and burial diagenesis. Authigenic phases in the North Aoba Basin include zeolite minerals, clay minerals, inorganic carbonate minerals, and authigenic quartz.

Drilling at Site 833, located near the western margin of North Aoba Basin (Fig. 1), penetrated a sill complex (Fig. 2). We submit that the observed mineralogical and chemical alteration overprint results from a recent sill intrusions.

Intrusion of the sill complex into water-saturated sediments would heat adjacent material and expel heated fluids into surrounding porous units. We base this model on the occurrence of depth controlled changes in authigenic minerals that suggest increasing intensity of 
alteration with proximity to the sill complex. The zeolite assemblage phillipsite plus heulandite (and the notable lack of analcime, chabazite, and thomsonite) occurs only in the vicinity of the sill. Carbonates that occur near the sill complex exhibit flower structures an external morphology typical of hydrothermally formed carbonates (Pl. 3). In the Guyamas Basin (Kastner, 1982) calcite and dolomite are present in the authigenic minerals assemblage attributed to hydrothermalism associated with sill intrusion; for a hydrothermal system connected with a magmatic chamber those minerals do not occur. This hydrothermal mechanism is a deuteritic alteration type: when the sill intrudes the sediments saturated with pore interstitial water, the temperature of these solutions increases. Alteration takes place on the border of the intrusion and the solutions migrate on the pore space of the sediments hosts, perpendicular to the axis of the sill.

Fe oxides, with rosette shape, show typical micro-morphology of deuteritic alteration of volcanic material. Authigenic quartz is observed in the deeper intervals near the sill complex. Clay minerals, such as the smectite group minerals saponite and nontronite, are observed associated with the zeolites and authigenic carbonates.

A sill complex was not encountered at Site 832, located in the deepest region of the basin. The zoned character of authigenic minerals is similar at Site 832 to sediments observed at Site 833, though the zeolite assemblages are more complex at Site 833 than at Site 832 . Dolomite and magnesite are present in the deeper parts of the sedimentary column. The presence of $\mathrm{Mg}$-carbonates in the deeper portions of the hole suggest that these sediments have been influenced by fluids that are more $\mathrm{Mg}$-enriched than fluids that have influenced shallower portions of the sedimentary sequence. We submit that the sill intrusion may have influenced sediments at Site 832, but that the sill may be outside the extent of drilling at this site. A specific REE signature is displayed for this altered samples. REE distribution normalized to arc tholeiite displays a pattern with enriched LREE in the upper samples. Ce and Eu negative anomalies characterized these samples except for those from the top of the holes. The volcaniclastic sediments are globally depleted when normalized to shale. This is interpreted as the result of hydrothermal effect. The sample the most depleted in REE (normalized to shale or tholeiite) is also affected by a strong P negative anomaly and characterized by a complex zeolitic assemblages (phillipsite, analcime, chabazite, and thomsonite). It confirms the hydrothermal origin of $\mathrm{P}$ in these deposits.

Samples of Site 833 show like those of Site 832 a global depletion in LREE, an Eu positive anomaly (normalized to shale) attributed to volcaniclastic phase (feldspar) (Henderson, 1984). A Ce negative anomaly (normalized to shale, restricted to few samples) is more accentuated at Site 833 than Site 832, less influenced by redox conditions (Fleet, 1984).

Fractionation LREE/HREE and redox incidences permit to define areas of typical marine deposits (Jarvis, 1985; Kunzendorf, 1988; Van der Flier-Keller, 1991). Our samples plotted on $\mathrm{La} / \mathrm{Ce}$ vs. Ce/La diagram (Fig. 19) show that the samples are situated in the marine basalts altered rocks area, and some of them from Site 833 are comparable with the hydrothermally affected ridge sediments (HARS). The North Aoba Basin's deposits provide an example of low hydrothermally affected intra-arc sediments.

Our model of sill injection as the mechanism driving hydrothermal alteration in North Aoba Basin relies heavily on the observed zonation of the zeolite assemblages. Major groups of minerals, which are used as tracers for alteration mechanisms are phyllosilicates, zeolites, and carbonates. Phyllosilicates are represented by $\mathrm{Mg}$ or Fe smectites, such as saponite and nontronite, which are typical of hydrothermal alteration. No beidellite occurs which could have been attributed to weathering. No nontronite transformation in celadonite appear like in some paleohydrothermal Mn crust from Vot Tande back arc trough, in the north New Hebrides back arc troughs (Gérard et al., 1987; Gérard, 1993). All this confirms recent (pliocene-pleistocene?) hydrothermal activity. Rare occurrence of chlorite points out a peak of stronger hydrothermal activity.
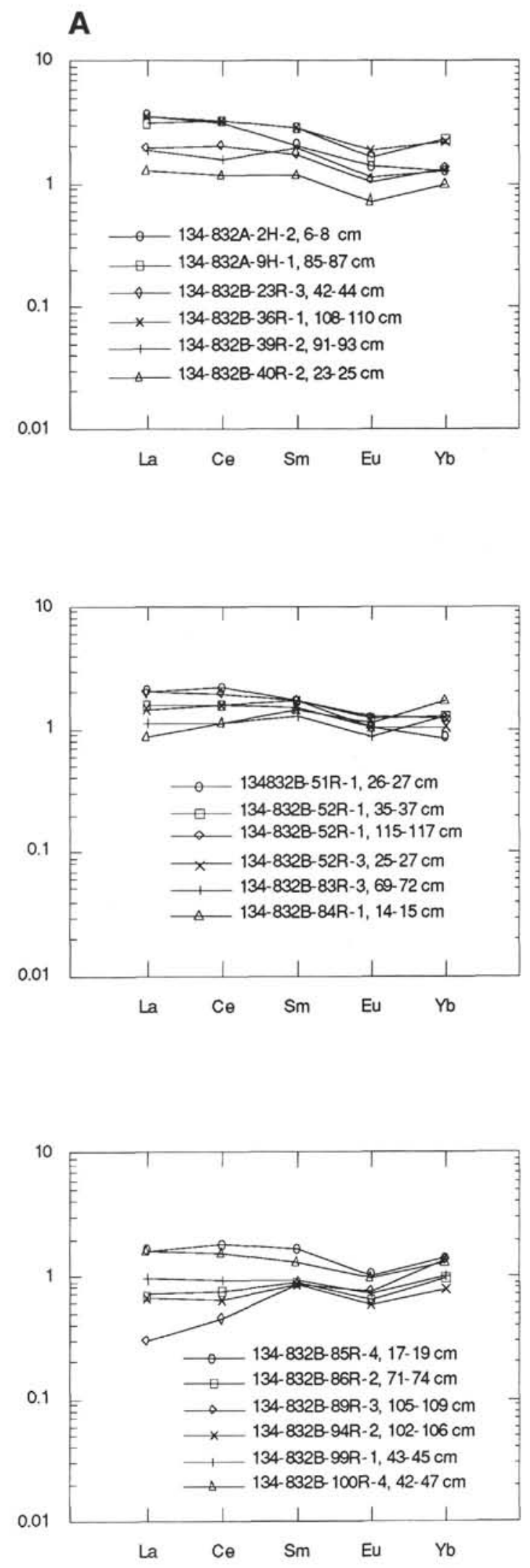

Figure 16. REE normalizations to arc tholeiites in samples from Site 832 (A) and Site 833 (B). 
B
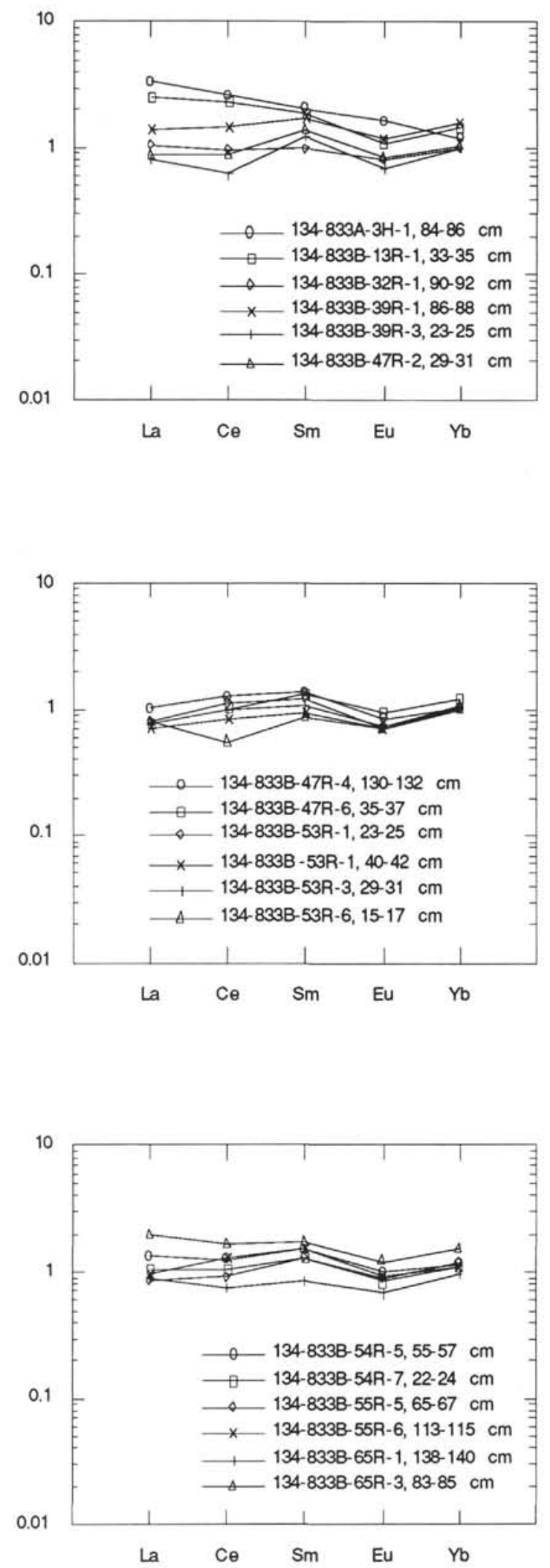

Figure 16 (continued).
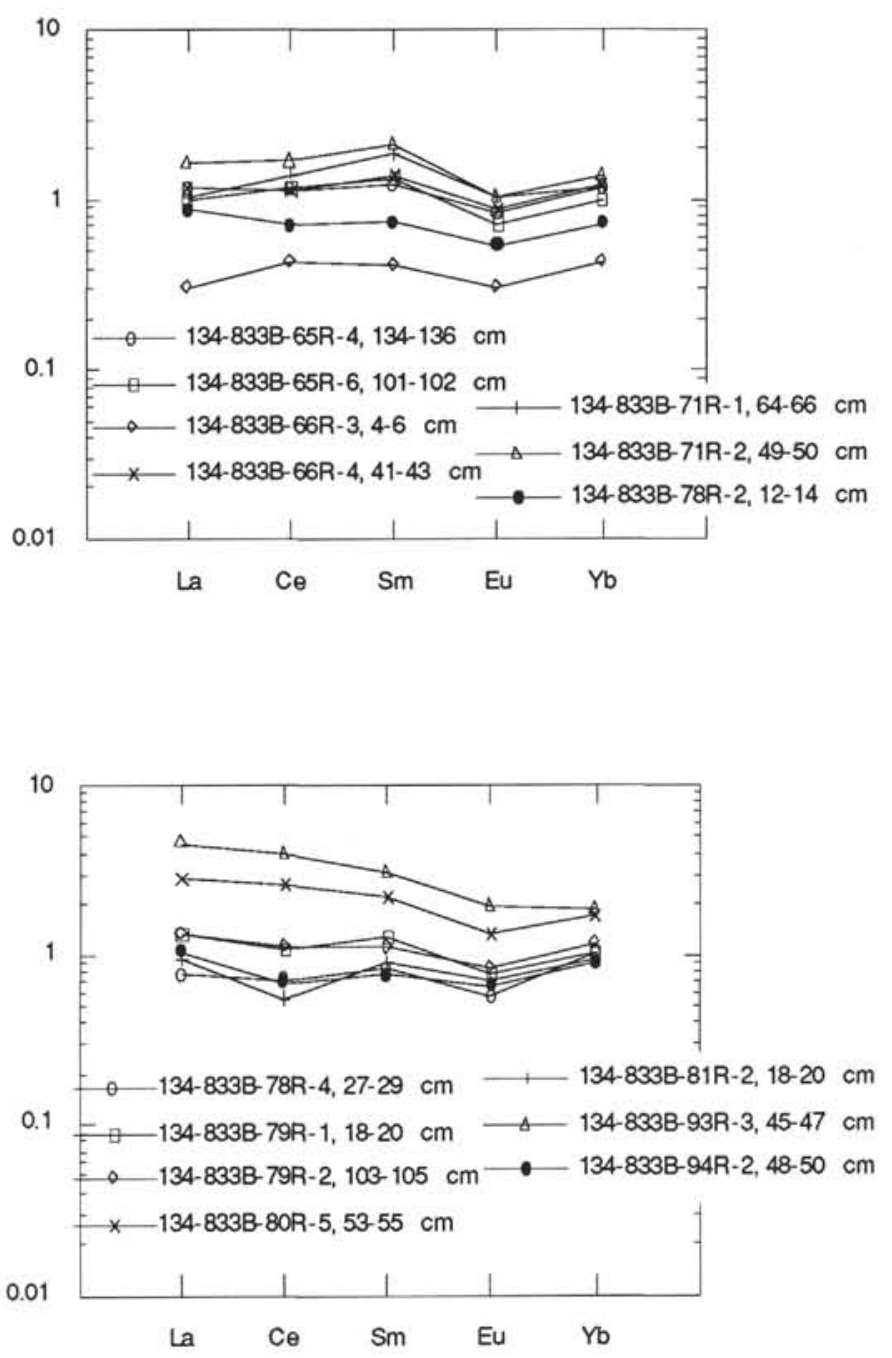
Table 11. Ca and $\mathrm{Sr}$ content and $\mathrm{Sr} / \mathrm{Ca}$ molar ratio.

\begin{tabular}{|c|c|c|c|c|c|c|c|c|c|c|}
\hline Unit & $N$ & Sample 134- & $\begin{array}{l}\text { Depth } \\
\text { (mbsf) }\end{array}$ & $\begin{array}{l}\mathrm{CaO} \\
(\%)\end{array}$ & $\begin{array}{c}\mathrm{Sr} \\
(\mathrm{ppm})\end{array}$ & $\begin{array}{c}\mathrm{Ca} \\
(\mathrm{mM} / \mathrm{kg})\end{array}$ & $\begin{array}{c}\mathrm{Sr} \\
(\mathrm{mM} / \mathrm{kg})\end{array}$ & $\mathrm{Sr} / \mathrm{Ca}$ & $\mathrm{CaO}$ & $\begin{array}{l}\mathrm{CaO} \\
\text { (free) }\end{array}$ \\
\hline $1 \mathrm{~A}$ & 1 & $832 \mathrm{~A}-2 \mathrm{H}-2,6-8$ & 7.4 & 5.66 & 773 & 1011 & 8.8 & 0.0087 & 5.66 & \\
\hline $1 \mathrm{~A}$ & 2 & $832 \mathrm{~A}-19 \mathrm{H}-1,85-87$ & 141.85 & 6.09 & 420 & 1088 & 4.8 & 0.0044 & 6.09 & 3.65 \\
\hline IB & 3 & $832 \mathrm{~B}-23 \mathrm{R}-3,42-44$ & 360.02 & 13.76 & 696 & 2457 & 7.9 & 0.0032 & 13.76 & 4.63 \\
\hline 3 & 4 & $832 \mathrm{~B}-36 \mathrm{R}-1,108-110$ & 481.88 & 9.19 & 549 & 1641 & 6.3 & 0.0038 & 9.19 & 4.32 \\
\hline 3 & 5 & 832B-39R-2, 91-93 & 512.21 & 20.06 & 659 & 3582 & 7.5 & 0.0021 & 20.06 & 5.2 \\
\hline 3 & 6 & $832 \mathrm{~B}-40 \mathrm{R}-2,23-25$ & 521.23 & 19.28 & 715 & 3443 & 8.2 & 0.0024 & 19.28 & 3.39 \\
\hline 4 & 7 & $832 \mathrm{~B}-51 \mathrm{R}-1,26-27$ & 625.96 & 9.28 & 334 & 1657 & 3.8 & 0.0023 & 9.28 & 8.65 \\
\hline 4 & 8 & $832 \mathrm{~B}-52 \mathrm{R}-1,35-37$ & 635.65 & 11.5 & 446 & 2054 & 5.1 & 0.0025 & 11.5 & 10.48 \\
\hline 4 & 9 & $832 \mathrm{~B}-52 \mathrm{R}-1,115-117$ & 636.45 & 9.28 & 798 & 1657 & 9.1 & 0.0055 & 9.28 & 8.79 \\
\hline 4 & 10 & $832 \mathrm{~B}-52 \mathrm{R}-3,25-27$ & 638.61 & 9.41 & 259 & 1680 & 3 & 0.0018 & 9.41 & 8.77 \\
\hline 6 & 11 & $832 \mathrm{~B}-83 \mathrm{R}-3,69-72$ & 936.99 & 7.69 & 209 & 1373 & 2.4 & 0.0017 & 7.69 & 5.56 \\
\hline 6 & 12 & $832 \mathrm{~B}-84 \mathrm{R}-1,14-15$ & 943.04 & 4 & 399 & 714 & 4.6 & 0.0064 & 4 & 3.12 \\
\hline 7 & 13 & $832 \mathrm{~B}-85 \mathrm{R}-4,17-19$ & 957.27 & 7.44 & 447 & 1329 & 5.1 & 0.0038 & 7.44 & 2.54 \\
\hline 7 & 14 & 832B-86R-2. 71-74 & 977.91 & 8.1 & 210 & 1446 & 2.4 & 0.0017 & 8.1 & 6.18 \\
\hline 7 & 15 & $832 \mathrm{~B}-89 \mathrm{R}-3,105-109$ & 994.85 & 6.91 & 210 & 1234 & 2.4 & 0.0019 & 6.91 & 4.26 \\
\hline 7 & 16 & $832 \mathrm{~B}-94 \mathrm{R}-2,102-106$ & 1041.52 & 5.66 & 116 & 1011 & 1.3 & 0.0013 & 5.66 & \\
\hline 7 & 17 & $832 \mathrm{~B}-99 \mathrm{R}-1,43-45$ & 1087.73 & 4.66 & 255 & 832 & 2.9 & 0.0035 & 4.66 & 3.14 \\
\hline 7 & 18 & $832 \mathrm{~B}-100 \mathrm{R}-4,42-47$ & 1101.92 & 7.94 & 213 & 1418 & 2.4 & 0.0017 & 7.94 & 6.91 \\
\hline $1 \mathrm{~A}$ & 1 & $833 \mathrm{~A}-3 \mathrm{H}-1,84-86$ & 19.84 & 10 & 885 & 1786 & 10.1 & 0.0057 & 10 & 9.36 \\
\hline $2 \mathrm{~B}$ & 2 & $833 \mathrm{~B}-13 \mathrm{R}-1,33-35$ & 193.43 & 16.46 & 592 & 2939 & 6.8 & 0.0023 & 16.46 & 4.8 \\
\hline 3 & 3 & $833 \mathrm{~B}-32 \mathrm{R}-1,90-92$ & 376.7 & 9.21 & 374 & 1645 & 4.3 & 0.0026 & & \\
\hline 3 & 4 & $833 \mathrm{~B}-39 \mathrm{R}-1,86-88$ & 444.06 & 7 & 156 & 1250 & 1.8 & 0.0014 & 7 & 3.29 \\
\hline 3 & 5 & $833 \mathrm{~B}-39 \mathrm{R}-3,23-25$ & 444.43 & 9.05 & 496 & 1616 & 5.7 & 0.0035 & 9.05 & 7.98 \\
\hline 3 & 6 & $833 B-47 R-2,29-31$ & 501.79 & 11.33 & 349 & 2023 & 4 & 0.002 & 11.33 & 10.05 \\
\hline 3 & 7 & $833 \mathrm{~B}-47 \mathrm{R}-4,130-132$ & 505.8 & 10.49 & 226 & 1873 & 2.6 & 0.0014 & 10.49 & 9.23 \\
\hline 3 & 8 & $833 \mathrm{~B}-47 \mathrm{R}-6,35-37$ & 507.85 & 9.8 & 235 & 1750 & 2.7 & 0.0015 & 9.8 & 8.07 \\
\hline 3 & 9 & $833 \mathrm{~B}-53 \mathrm{R}-1,23-25$ & 558.13 & 9.71 & 294 & 1734 & 3.4 & 0.0019 & 9.71 & 8.8 \\
\hline 3 & 10 & $833 B-53 R-1,40-42$ & 558.3 & 9.71 & 256 & 1734 & 2.9 & 0.0017 & 9.71 & 7.98 \\
\hline 3 & 11 & $833 \mathrm{~B}-53 \mathrm{R}-3,29-31$ & 561.19 & 9.69 & 275 & 1730 & 3.1 & 0.0018 & 9.69 & 8.13 \\
\hline 3 & 12 & 833B-53R-6, $15-17$ & 565.55 & 10.3 & 278 & 1839 & 3.2 & 0.0017 & 10.3 & 6.28 \\
\hline 3 & 13 & $833 \mathrm{~B}-54 \mathrm{R}-5,55-57$ & 574.35 & 9.24 & 305 & 1650 & 3.5 & 0.0021 & & \\
\hline 3 & 14 & $833 \mathrm{~B}-54 \mathrm{R}-7,22-24$ & 577.02 & 9.62 & 30 & 1714 & 2.6 & 0.0015 & 9.6 & 8.33 \\
\hline 4 & 15 & $833 \mathrm{~B}-55 \mathrm{R}-5,65-67$ & 584.35 & 11.25 & 307 & 2009 & 3.5 & 0.0017 & & \\
\hline 4 & 16 & 833B-55R-6, 113-115 & 586.33 & 10.58 & 409 & 1889 & 4.7 & 0.0025 & 10.58 & 9.15 \\
\hline 4 & 17 & $833 \mathrm{~B}-65 \mathrm{R}-1,138-140$ & 675.58 & 10.85 & 13 & 1929 & 5.9 & 0.003 & 10.8 & 3.31 \\
\hline 4 & 18 & $833 \mathrm{~B}-65 \mathrm{R}-3,83-85$ & 678.03 & 9.46 & 389 & 1689 & 4.4 & 0.0026 & 9.46 & 5.72 \\
\hline 4 & 19 & $833 \mathrm{~B}-65 \mathrm{R}-4,134-136$ & 680.04 & 11.23 & 719 & 2005 & 8.2 & 0.0041 & 11.23 & 7.83 \\
\hline 4 & 20 & $833 \mathrm{~B}-65 \mathrm{R}-6,101-103$ & 682.71 & 9.25 & 890 & 1652 & 10.2 & 0.0061 & 9.25 & 4.25 \\
\hline 4 & 21 & 833B-66R-3, 4-6 & 686.84 & 9.38 & 471 & 1675 & 5.4 & 0.0032 & 9.38 & 8.2 \\
\hline 4 & 22 & $833 \mathrm{~B}-66 \mathrm{R}-4,41-43$ & 688.71 & 8.33 & 443 & 1488 & 5.1 & 0.0034 & 8.33 & 4.04 \\
\hline 4 & 23 & $833 \mathrm{~B}-71 \mathrm{R}-1,64-66$ & 732.84 & 9.85 & 1612 & 1759 & 18.4 & 0.0105 & 9.85 & 7.9 \\
\hline 4 & 24 & 833B-71R-2, 49-51 & 734.19 & 17.63 & 488 & 3148 & 5.6 & 0.0018 & 17.6 & 31.39 \\
\hline 4 & 25 & 833B-78R-2, $12-14$ & 800.62 & 29.67 & 58 & 5280 & 8.7 & 0.0016 & & \\
\hline 4 & 26 & 833 B $-78 R-4,27-29$ & 803.77 & 8.39 & 346 & 1498 & 3.9 & 0.0026 & 8.39 & -6.11 \\
\hline 4 & 27 & 833B-79R-1, $18-20$ & 808.88 & 18.39 & 492 & 3284 & 5.6 & 0.0017 & & \\
\hline 4 & 28 & 833B-79R-2, 103-105 & 811.23 & 14.91 & 715 & 2663 & 8.2 & 0.0031 & 14.91 & 1.31 \\
\hline 4 & 29 & $833 \mathrm{~B}-80 \mathrm{R}-5,53-55$ & 824.83 & 10.48 & 717 & 1871 & 8.2 & 0.0044 & 10.48 & 1.56 \\
\hline 4 & 30 & $833 \mathrm{~B}-81 \mathrm{R}-2,18-20$ & 829.68 & 18.66 & 939 & 3332 & 10.7 & 0.0032 & 18.66 & 1.51 \\
\hline 5 & 31 & $833 \mathrm{~B}-93 \mathrm{R}-3,45-47$ & 937.05 & 11.74 & 3118 & 2096 & 35.6 & 0.017 & & \\
\hline 5 & 32 & $833 \mathrm{~B}-94 \mathrm{R}-2,48-50$ & 945.28 & 18.89 & 19 & 3350 & 10.5 & 0.0031 & & \\
\hline
\end{tabular}

Note: $\mathrm{CaO}$ content on carbonate free basis (calcite reference).

Table 12. Correlation values between $\mathrm{K}_{2} \mathrm{O}$, $\mathrm{TiO}_{2}, \mathrm{P}_{2} \mathrm{O}_{5}$, and $\mathrm{REE}$.

\begin{tabular}{|c|c|c|c|c|c|c|c|c|c|c|c|c|c|c|}
\hline & $n$ & $p>0.001$ & $\mathrm{p}>0.01$ & $\mathrm{La}$ & $\mathrm{Ce}$ & $\mathrm{Nd}$ & $\mathrm{Sm}$ & Eu & Gd & Dy & Er & $\mathrm{Yb}$ & $\mathrm{Lu}$ & $\mathrm{Y}$ \\
\hline \multicolumn{15}{|l|}{$\mathrm{K}_{2} \mathrm{O}$} \\
\hline ODP 832 & 17 & $r>0.693$ & $r>0.575$ & 0.672 & 0.682 & 0.736 & 0.794 & 0.819 & 0.857 & 0.886 & 0.888 & $\underline{0.89}$ & $\underline{0.89}$ & $\underline{0.879}$ \\
\hline ODP 833 & 27 & $r>0.580$ & $r>0.472$ & 0.662 & 0.552 & $\overline{0.568}$ & 0.338 & 0.406 & $\overline{0.205}$ & 0.215 & $\overline{0.083}$ & $\overline{0.198}$ & $\overline{0.098}$ & 0.257 \\
\hline ¿ODP & 44 & $r>0.470$ & $r>0.376$ & 0.683 & 0.645 & 0.673 & 0.574 & 0.633 & 0.553 & 0.592 & $\underline{0.494}$ & 0.597 & 0.535 & $\underline{0.596}$ \\
\hline $\mathrm{MgO}>5 \%$ & 26 & $r>0.589$ & $r>0.479$ & 0.236 & 0.206 & 0.172 & 0.06 & 0.129 & $-\overline{-0.102}$ & 0.024 & -0.188 & -0.002 & -0.169 & 0.058 \\
\hline $\mathrm{MgO}<5 \%$ & 18 & $r>0.679$ & $r>0.561$ & $\underline{0.722}$ & 0.706 & $\underline{0.735}$ & 0.67 & $\underline{0.793}$ & $\underline{0.728}$ & 0.727 & 0.63 & $\underline{0.694}$ & 0.663 & $\underline{0.708}$ \\
\hline $\mathrm{TiO}_{2}$ & & & & & & & & & & & & & & - \\
\hline ODP 832 & 17 & $r>0.693$ & $r>0.575$ & 0.051 & 0.104 & 0.174 & 0.2 & 0.405 & 0.244 & 0.446 & 0.301 & 0.455 & 0.326 & 0.409 \\
\hline ODP 833 & 27 & $r>0.580$ & $r>0.472$ & 0.462 & 0.404 & 0.452 & 0.376 & 0.565 & 0.244 & 0.341 & 0.123 & 0.227 & 0.176 & 0.249 \\
\hline$\Sigma O D P$ & 44 & $r>0.470$ & $r>0.376$ & 0.261 & 0.272 & 0.324 & 0.295 & $\underline{0.497}$ & 0.275 & 0.448 & 0.252 & 0.421 & 0.302 & 0.389 \\
\hline $\mathrm{MgO}>5 \%$ & 26 & $r>0.589$ & $r>0.479$ & 0.675 & 0.621 & 0.692 & 0.588 & 0.693 & 0.484 & 0.55 & 0.292 & 0.454 & 0.33 & 0.485 \\
\hline $\mathrm{MgO}<5 \%$ & 18 & $r>0.679$ & $r>0.561$ & 0.064 & 0.09 & $\overline{0.141}$ & 0.114 & $\overline{0.38}$ & 0.135 & 0.389 & 0.202 & 0.408 & 0.27 & 0.327 \\
\hline \multicolumn{15}{|l|}{$\mathrm{P}_{2} \mathrm{O}_{5}$} \\
\hline ODP 832 & 17 & $r>0.693$ & $r>0.575$ & $\underline{0.845}$ & $\underline{0.837}$ & 0.867 & $\underline{0.822}$ & $\underline{0.884}$ & $\underline{0.765}$ & 0.695 & 0.587 & 0.6 & 0.556 & 0.688 \\
\hline ODP 833 & 27 & $r>0.580$ & $r>0.472$ & $\underline{0.839}$ & 0.726 & $\underline{0.807}$ & 0.561 & 0.724 & 0.378 & 0.605 & 0.277 & $\underline{0.581}$ & 0.397 & $\underline{0.69}$ \\
\hline ¿ODP & 44 & $r>0.470$ & $r>0.376$ & 0.841 & 0.777 & 0.827 & $\underline{0.673}$ & $\underline{0.795}$ & $\underline{0.559}$ & 0.655 & 0.415 & 0.594 & 0.466 & 0.696 \\
\hline $\mathrm{MgO}>5 \%$ & 26 & $r>0.589$ & $r>0.479$ & 0.851 & 0.739 & 0.774 & 0.485 & 0.678 & 0.343 & 0.524 & 0.091 & 0.445 & 0.238 & 0.537 \\
\hline $\mathrm{MgO}<5 \%$ & 18 & $r>0.679$ & $r>0.561$ & $\underline{0.822}$ & 0.761 & 0.828 & $\underline{0.714}$ & 0.828 & 0.597 & 0.655 & 0.475 & 0.577 & 0.461 & $\underline{0.723}$ \\
\hline
\end{tabular}

Notes: Minimum values (r) are represented for probability (p) of $1 \%$ and 1 . Underlined data indicate significative value ( $r>$ minimum value). 
Zeolite minerals have been observed in many Cretaceous and Tertiary age marine sedimentary sections in the Indian (Stakes et al., 1991), Pacific (Bass et al., 1973; Honnorez et al., 1983; Viereck et al., 1986; Lee, 1988), and Atlantic (Desprairies et al., 1984; Morton and Keen, 1984; Simon and Schmincke, 1984) oceans. Others have attributed zeolite zonation to burial metamorphism in regions of normal geothermal gradient (e.g., Iijima and Utada, 1971) and to polyphase hydrothermal alteration at temperatures in excess of $100^{\circ} \mathrm{C}$ observed in Iceland (Walker, 1960; Viereck et al., 1982) or Réunion Island (Rançon, 1985). Gottardi (1989) provides a useful review of zeolite facies and their origins: normal burial diagenesis, very low-grade metamorphism, hydrothermal genesis, formation in vugs and geodes in basalts, and magmatic origins. Based on the order of appearance with depth of the zeolite minerals (phillipsite $<$ analcime $<$ chabazite $<$ thomsonite $<$ heulandite $<$ erionite), we place the assemblage observed in the North Aoba Basin at the upper limit of normal burial diagenetic temperature or at the lower limit of the hydrothermal temperature zone. However, we observed analcime as shallow as 200 mbsf, shallower than one would expect under burial diagenesis.

Phillipsite and analcime are nearly ubiquitous and contemporaneous. The other zeolites (chabazite, thomsonite, and heulandite) appear progressively with depth. Analcime does not increase strictly with depth. Near and above the sill, no analcime occurs. The distribution of zeolites is dependent of the sill. In case of diagenesis effect or low temperature metamorphism a mineralogical succession associated with burial depth is noticeable. In the case of low temperature hydrothermalism (Utada, 1980) this succession is reversely connected to the source (sill intrusion for example). Thus, we invoke thermally enhanced diagenesis or low grade hydrothermal alteration to explain the assemblage observed. Sill injection may be the mechanism that provided an anomalous pulse of thermal input to the sedimentary column.

The different zeolites assemblages are related to chemical composition of altered material and to polarity of hydrothermal fluids (from the bottom of the basin or sill intrusions, to the top). At Site 833, a basal zonation is noticed for zeolites, associated with sill intrusion (Table 5). Near sill sediments are depleted in zeolites but they are also characterized by low primary porosity, which seems here a very efficient phenomena to stop the zeolitization. The authigenic minerals that occur in the upper sediments of pleistocene age may be attributed to solutions of different origin and higher temperatures than the temperatures of the recent interstitial solutions.

\section{ACKNOWLEDGMENTS}

We would like to thank Anne Struz, Scripps Institution of Oceanography, for helpful manuscript reviews.

We acknowledge valuable discussions with Alain Blot and JeanMarie Wackermann, ORSTOM.

\section{REFERENCES}

Al-Aasm, I.S., and Blaise, B., 1991. Interaction between hemipelagic sediment and a hydrothermal system: Middle Valley, northern Juan de Fuca Ridge, subarctic northeast Pacific. Mar. Geol., 98:25-40.

Baker, P.A., Gieskes, J.M., and Elderfield, H., 1982. Diagenesis of carbonates in deep-sea sediments: evidence from $\mathrm{Sr}^{2+} / \mathrm{Ca}^{2+}$ ratios and interstitial dissolved $\mathrm{Sr}^{2+}$ data. J. Sediment. Petrol., 52:71-82.

Barsdell, M., Smith, I.E.M., and Sporli, K.B., 1982. The origin of reversed geochemical zoning in the Northern New Hebrides Volcanic Arc. Contrib. Mineral. Petrol., 81:148-155.

Bass, M.N., Moberly, R., Rhodes, J.M., Shih, C.C., and Church, S.E., 1973. Volcanic rocks cored in the central Pacific, Leg 17, Deep Sea Drilling

\footnotetext{
Abbreviations for names of organizations and publications in ODP reference lists follow the style given in Chemical Abstracts Service Source Index (published by American Chemical Society).
}

Project. In Winterer, E.L., Ewing, J.I., et al., Init. Repts. DSDP, 17: Washington (U.S. Govt. Printing Office), 429-503.

Briqueu, L., 1985. Etude du magmatisme associé aux zones de subduction à l'aide de traceurs géochimiques multiples: éléments traces et rapports isotopiques ${ }^{87} \mathrm{Sr} /{ }^{86} \mathrm{Sr}$ et ${ }^{143} \mathrm{Nd} /{ }^{144} \mathrm{Nd}$ [Thèse]. Univ. Montpellier, Doc. Trav. Cent. Geolog. Geophys., 5.

Collot, J.-Y., Greene, H.G., Stokking, L.B., et al., 1992. Proc. ODP, Init. Repts., 134: College Station, TX (Ocean Drilling Program).

Cullers, R.L., and Graf, J.L., 1984. Rare earth element in igneous rocks of the continental crust: intermediate and silicic rocks-ore petrogenesis. In Henderson, P. (Ed.), Rare Earth Element Geochemistry: Amsterdam (Elsevier), 275-308.

Desprairies, A., 1983. Relation entre le paramètre b des smectites et leur contenu en fer et magnésium. Application à l'étude des sédiments. Clay Miner., 18:165-175.

Desprairies, A., Bonnot-Courtois, C., Jehanno, C., Vernhet, S., and Joron, J.L., 1984. Mineralogy and geochemistry of alteration products in Leg 81 basalts. In Roberts, D.G., Schnitker, D., et al., Init. Repts. DSDP, 81: Washington (U.S. Govt. Printing Office), 733-742.

Fisher, R.V., and Schmincke, H.-U., 1984. Pyroclastic Rocks: New York (Springer-Verlag).

Fleet, A.J., 1984. Aqueous and sedimentary geochemistry of the rare earth elements. In Henderson, P. (Ed.), Rare Earth Element Geochemistry: New York (Elsevier), 343-373.

Gérard, M., 1993. Bassins d'arc et fossés arrière-arc dans un contexte de collision/subduction: l'arc des Nouvelles-Hébrides. Hydrothermalisme, néogenèses et diagenèse d'une série volcano-sédimentaire [Thèse de doctorat (Ph.D.)\}. Univ. de Paris 11.

Gérard, M., Person, A., Recy, J., and Dubois, J., 1987. Preliminary results of petrological and mineralogical studies of manganesiferous encrustations dredged over the New Hebrides back arc (Vanuatu). Terra Cognita, 7:189.

Gorton, M.P., 1974. The geochemistry and geochronology of the New Hebrides [Ph.D. dissert.]. Australian National Univ., Canberra.

1977. The geochemistry and origin of Quaternary volcanism in the New Hebrides. Geochim. Cosmochim. Acta, 41:1257-1270.

Gottardi, G., 1989. The genesis of zeolites. Eur. J. Mineral., 1:479-487.

Gottardi, G., and Galli, E., 1985. Natural Zeolites: Berlin (Springer-Verlag).

Gromet, L.P., Dymek, R.F., Haskin, L.A., and Korotev, R.L., 1984. The "North American Shale Composite": its compilation, major and trace element characteristics. Geochim. Cosmochim. Acta, 48:2469-2482.

Henderson, P., 1984. General geochemical properties and abundances of the rare earth elements. In Henderson, P. (Ed.), Rare Earth Element Geochemistry: New York (Elsevier), 1-29.

Hodkinson, R.A., and Cronan, D.S., 1991. Geochemistry of Recent hydrothermal sediments in relation to tectonic environment in the Lau Basin, southwest Pacific. Mar. Geol., 98:353-366.

Hoffert, M., Cheminée, J.L., Larqué, P., and Person, A., 1987. Dépôt hydrothermal associé au volcanisme sous-marin "intraplaque océanique." Prélèvements effectués acec Cyana sur le volcan Téahitia. C.R. Acad. Sci. Ser. 2, 304:829-833.

Hoffert, M., Person, A., Courtois, C., Karpoff, A.M., and Trauth, D., 1980. Sedimentology, mineralogy and geochemistry of hydrothermal deposits from Holes 424, 424A, 424B and 424C (Galapagos spreading center). In Rosendahl, B.R., Hekinian, R., et al., Init. Repts. DSDP, 54: Washington (U.S. Govt. Printing Office), 339-376.

Honnorez, J., Laverne, C., Hubberten, H.-W., Emmermann, R., and Muehlenbachs, K., 1983. Alteration processes in Layer 2 basalts from Deep Sea Drilling Project Hole 504B, Costa Rica Rift. In Cann, J.R., Langseth, M.G., Honnorez, J., Von Herzen, R.P., White, S.M., et al., Init. Repts. DSDP, 69: Washington (U.S. Govt. Printing Office), 509-546.

Iijima, A., 1978. Geological occurrences of zeolite in marine environments. In Sand, L.B., and Mumpton, F.A., (Eds.), Natural Zeolites Occurrence, Properties, Use: Oxford (Pergamon Press), 175-198.

Iijima, A., and Utada, M., 1971. Present-day zeolitic diagenesis of the Neogene geosynclinal deposits in the Niigata oil field, Japan. In Gould, R.F. (Ed.), Molecular Sieve Zeolites 1. Am. Chem. Soc., Adv. Chem. Ser., 101:342349.

Jarvis, I., 1985. Geochemistry and origin of Eocene-Oligocene metalliferous sediments from the central equatorial Pacific: Deep Sea Drilling Project Site 573 and 574. In Mayer, L., Theyer, F., Thomas, E., et al., Init. Repts. DSDP, 85: Washington (U.S. Govt. Printing Office), 781-804.

Kastner, M., 1982. Evidence for two distinct hydrothermal systems in the Guaymas Basin. In Curray, J.R., Moore, D.G., et al., Init. Repts. DSDP, 64 (Pt. 2): Washington (U.S. Govt. Printing Office), 1143-1157. 
Kunzendorf, H., Stoffers, P., and Gwozdz, R., 1988. Regional variations of REE patterns in sediments from active plate boundaries. Mar. Geol., 84:191-199.

Lee, Y.I., 1988. Chemistry and origin of zeolites in sandstones at DSDP Sites 445 and 446, Daito Ridge and Basin Province, Northwest Pacific. Chem. Geol., 67:261-273.

Macfarlane, A., Carney, J.N., Crawford, A.J., and Greene, H.G., 1988. Vanuatu-a review of the onshore geology. In Greene, H.G., and Wong, F.L. (Eds.), Geology and Offshore Resources of Pacific Island Arcs-Vanuatu Region. Circum-Pac. Counc. Energy Miner. Resour., Earth Sci. Ser. 8:45-91.

Mallick, D.I.J., and Neef, G., 1974. Geology of Pentecost. Reg. Rep.-New Hebrides Geol. Surv.

Monjaret, M.C., 1989. Le magmatisme des fossés à l'arrière de l'arc des Nouvelles-Hébrides (Vanuatu). (Campagne Seapso 2 du NO Jean Charcot). Implications géodynamiques: chronologie, pétrologie, géochimie [Thèse de doctorat (Ph.D.)]. Univ. Bretagne Occidentale, 1.

Morton, A.C., and Keene, J.B., 1984. Paleogene pyroclastic volcanism in the Southwest Rockall Plateau. In Roberts, D.G., Schnitker, D., et al., Init. Repts. DSDP, 81: Washington (U.S. Govt. Printing Office), 633-643.

Mumpton, F.A., and Ormsby, W.C., 1978. Morphology of zeolites in sedimentary rocks by scanning electron microscopy. In Sand, L.B., and Mumpton, F.A. (Eds.), Natural Zeolites: Oxford (Pergamon Press), 113-132.

Person, A., and Melières, F., 1978. Rôle de la todorokite dans un modèle d'altération deutérique (hydrothermale), mis en évidence à la base d'une coulée volcanique du massif du Cézallier. C. R. Acad. Sci. Ser. D, 287:783 786.

Rançon, J.P., 1985. Hydrothermal history of Piton des Neiges Volcano (Reunion Island, Indian Ocean). J. Vol. Res., 26:297-315.

Schallreuter, R., 1984. Framboidal pyrite in deep-sea sediments. In Hay, W.W., Sibuet, J.-C., et al., Init. Repts. DSDP, 75: Washington (U.S. Govt. Printing Office), 875-891.

Simon, M., and Schmincke, H.-U., 1984. Late cretaceous volcaniclastic rocks from the Walvis Ridge, Southeast Atlantic, Leg 74. In Moore, T.C., Jr., Rabinowitz, P.D., et al., Init. Repts. DSDP, 74: Washington (U.S. Govt. Printing Office), 765-791.

Stakes, D., Mével, C., Cannat, M., and Chaput, T., 1991. Metamorphic stratigraphy of Hole 735B. In Von Herzen, R.P., Robinson, P.T., et al., Proc. ODP, Sci. Results, 118: College Station, TX (Ocean Drilling Program), $153-180$.

Sun, S.-S., and McDonough, W.F., 1989. Chemical and isotopic systematics of oceanic basalts: implications for mantle composition and processes. In Saunders, A.D., and Norry, M.J. (Eds.), Magmatism in the Ocean Basins. Geol. Soc. Spec. Publ. London, 42:313-345.

Utada, M., 1980. Hydrothermal alterations related to igneous activity in Cretaceous and Neogene formations of Japan. Min. Geol. Spec. Iss., 8:67-83.

Van der Flier-Keller, E., 1991. Geochemistry and mineralogy of sediments, Atlantis II Fracture Zone, southwest Indian Ocean. In Von Herzen, R.P., Robinson, P.T., et al., Proc. ODP, Sci. Results, 118: College Station, TX (Ocean Drilling Program), 145-151.

Viereck, L.G., Griffin, B.J., Schmincke, H.-U., and Pritchard, R.G., 1982. Volcaniclastic rocks of the Reydarfjordur Drill Hole, eastern Iceland. 2. Alteration. J. Geophys. Res., 87:6459-6476.

Viereck, L.G., Simon, M., Schmincke, H.-U., 1986. Primary composition, alteration and origin of Cretaceous volcaniclastic rocks, East Mariana Basin (Site 585, Leg 89). In Moberly, R., Schlanger, S.O., et al., Init. Repts. DSDP, 89: Washington (U.S. Govt. Printing Office), 529-553.

Walker, G.P.L., 1960. Zeolite zones and dike distribution in relation to the structure of the basalts of eastern Iceland. J. Geol., 68:515-528.

Date of initial receipt: 1 June 1992

Date of acceptance: 28 September 1993

Ms 134SR-038
A
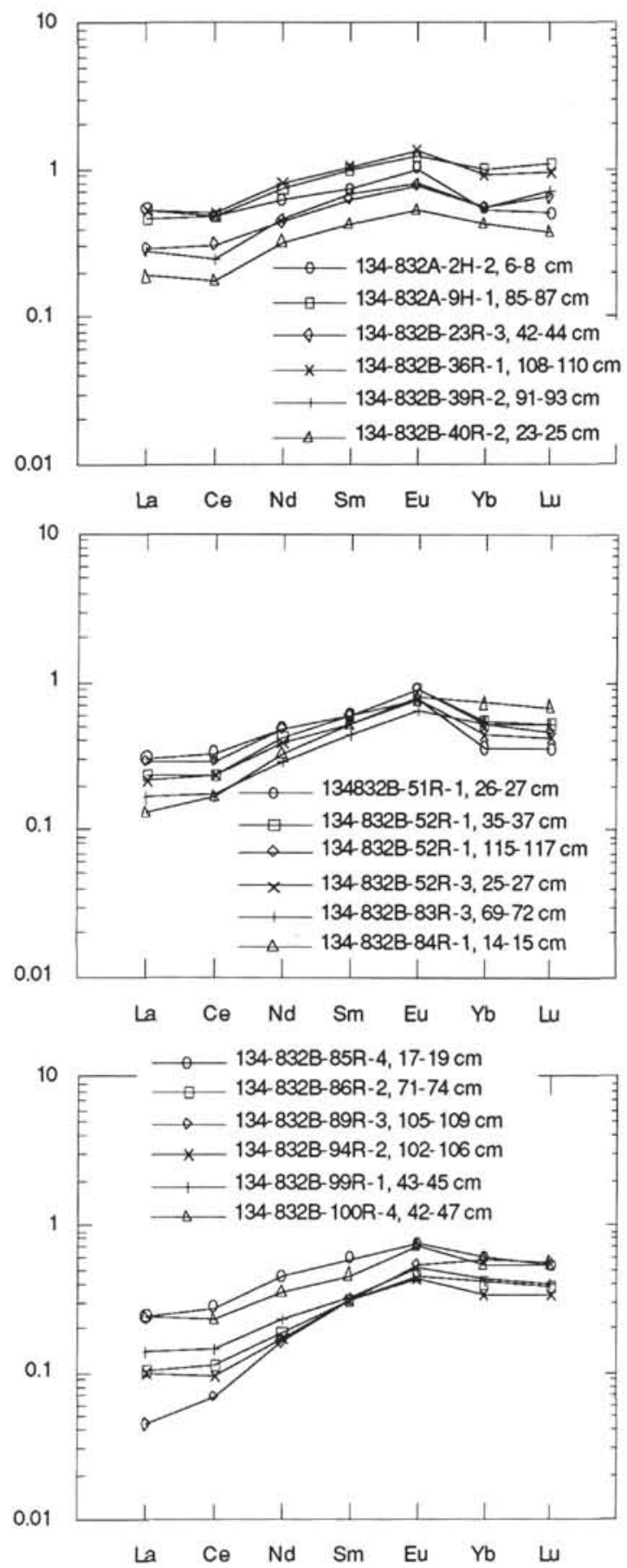

Figure 17. REE normalizations to North American shale composite in samples from Site 832 (A) and Site 833 (B). 
B
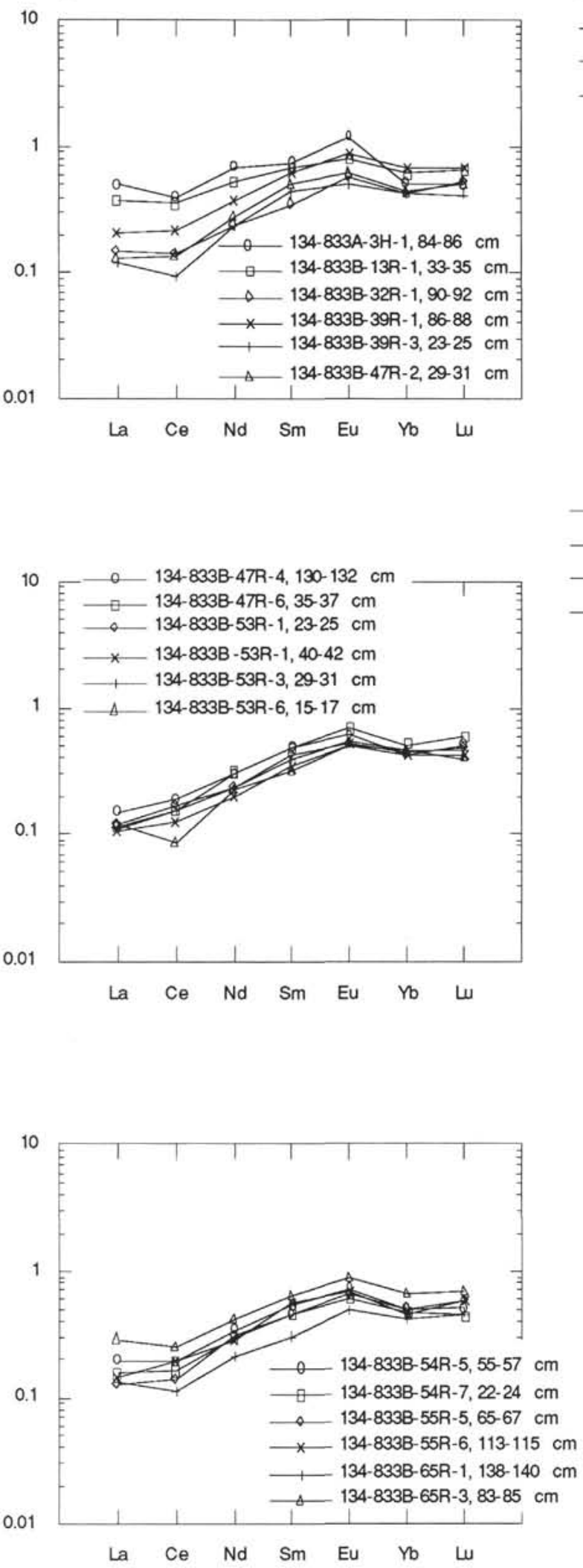

Figure 17 (continued).

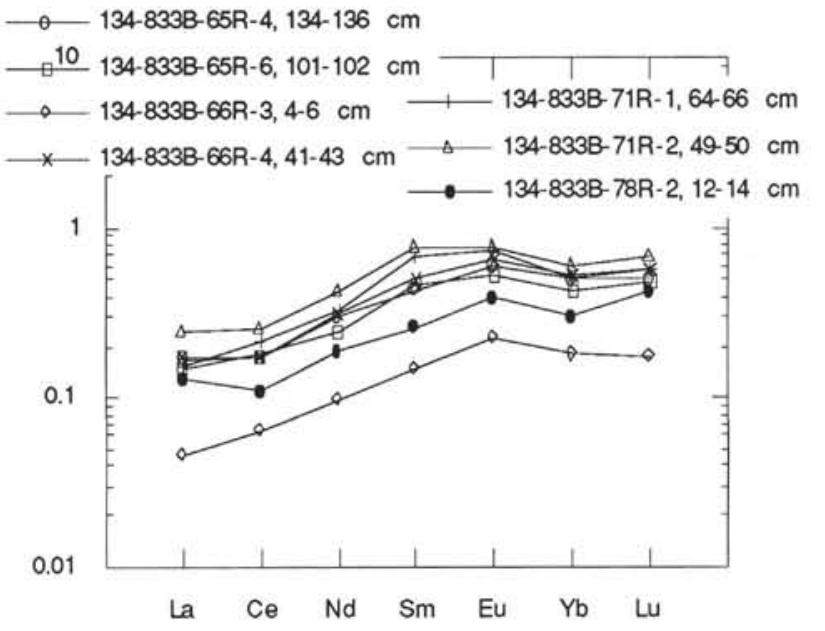

O $134-833 \mathrm{~B}-78 \mathrm{R}-4,27-29 \mathrm{~cm} \quad 134-833 \mathrm{~B}-81 \mathrm{R}-2,18-20 \mathrm{~cm}$ U 134-833B-79R-1, $18-20 \mathrm{~cm}$ - $134-833 \mathrm{~B}-93 \mathrm{R}-3,45-47 \mathrm{~cm}$ - 10134-833B-79R-2, $103-105 \mathrm{~cm} \longrightarrow$ 134-833B-94R-2, 48-50 cm $\times \quad 134-833 \mathrm{~B}-80 \mathrm{R}-5,53-55 \mathrm{~cm}$

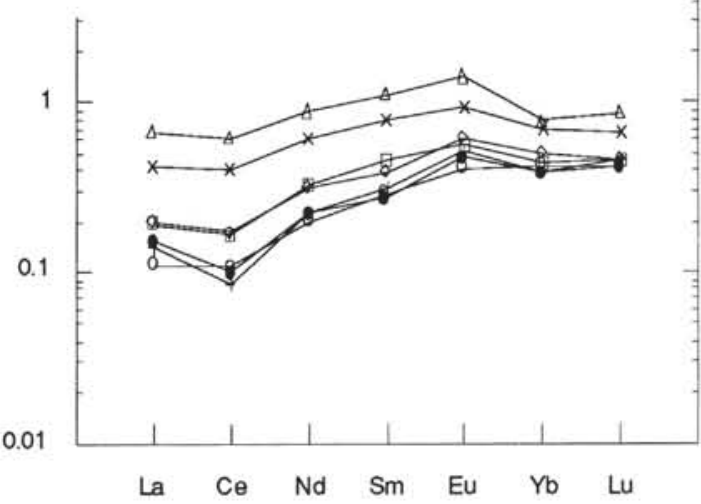


A
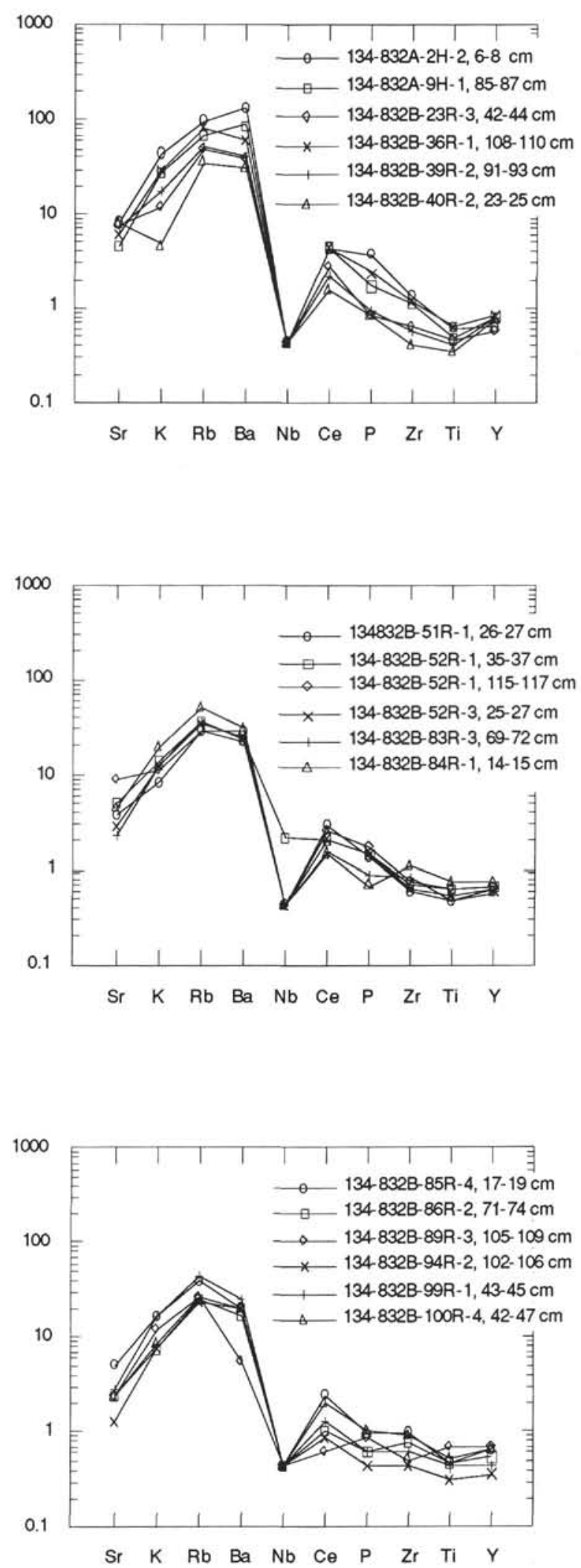

Figure 18. Normalizations to MORB in samples from Site 832 (A) and Site 833 (B). 
B
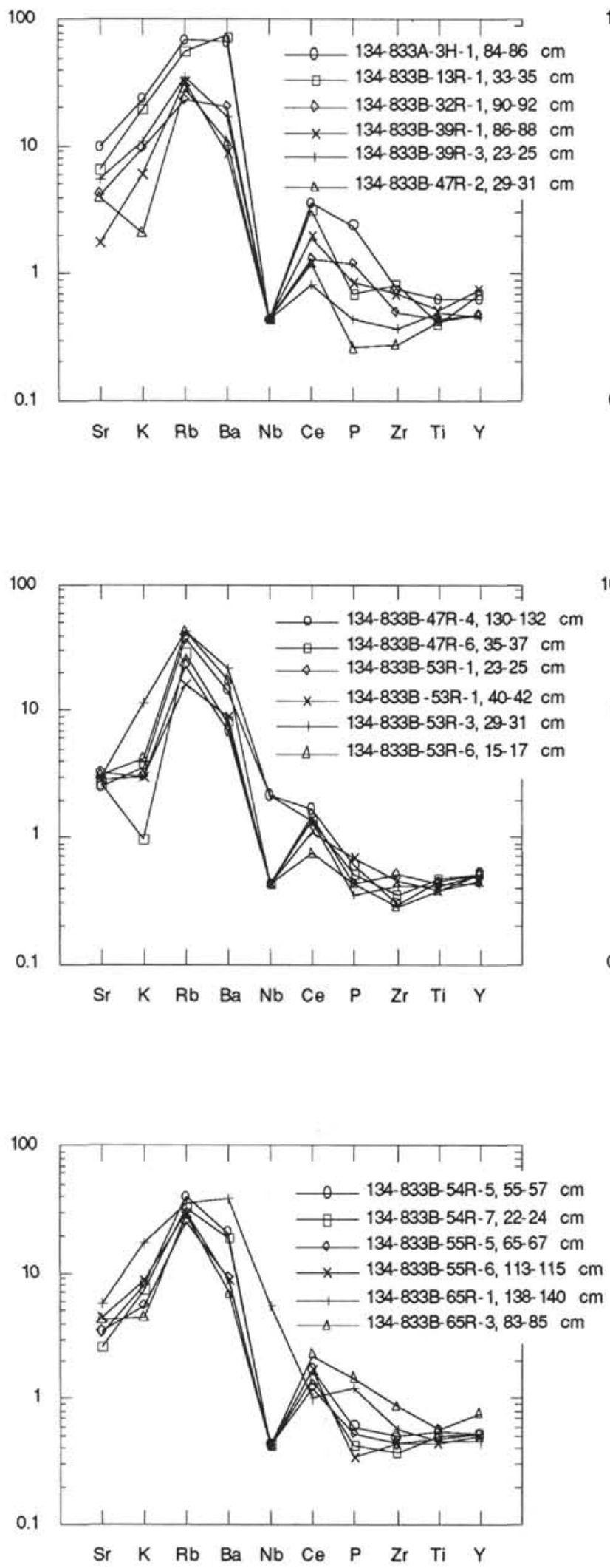

Figure 18 (continued).
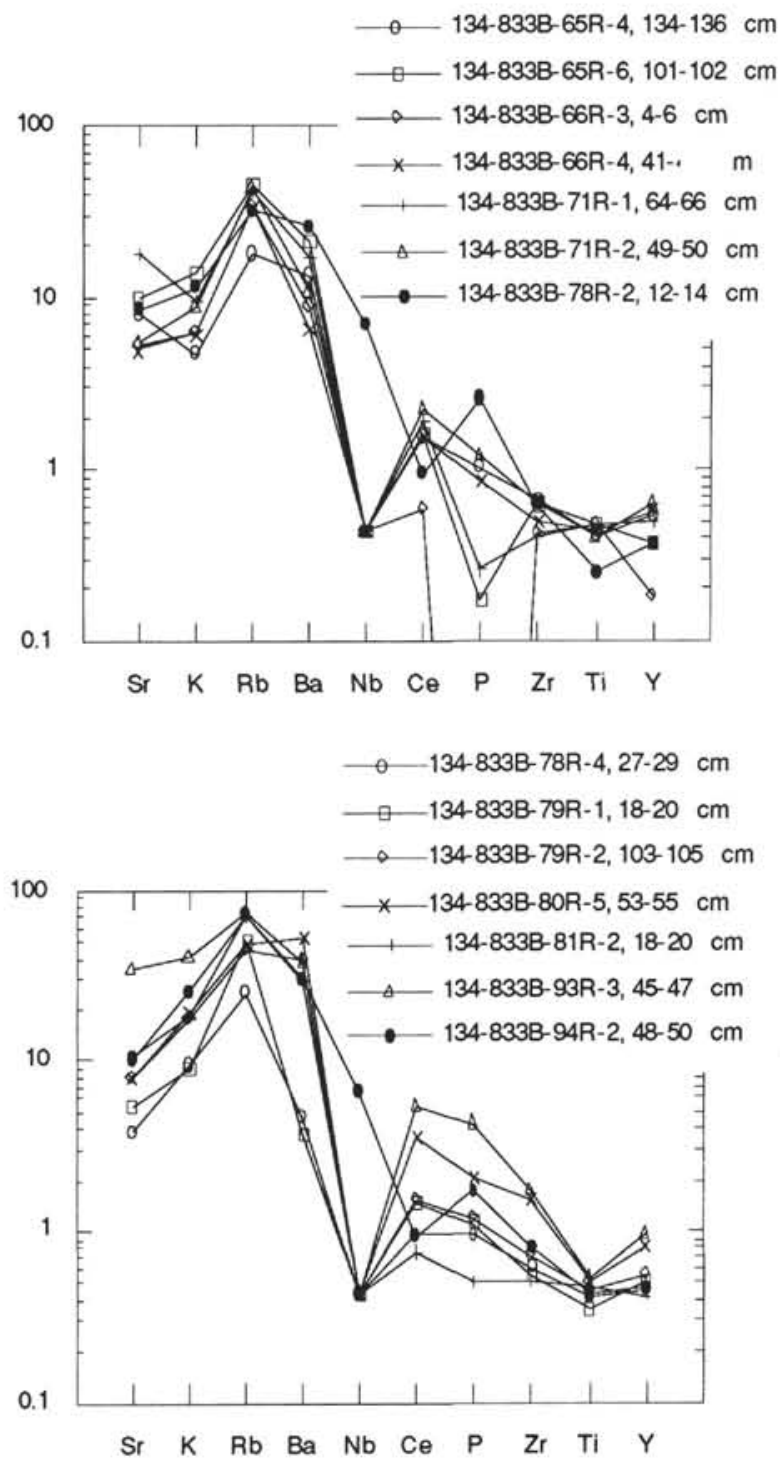


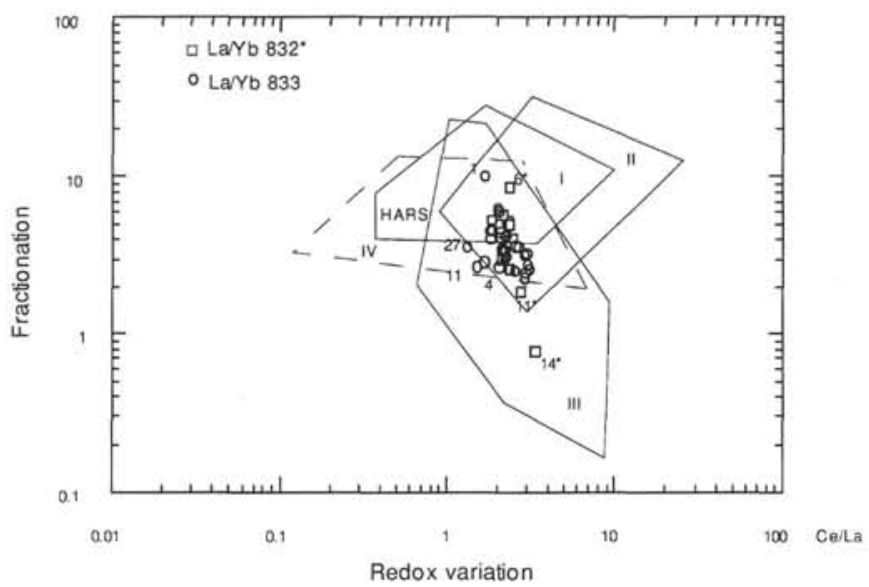

Figure 19. La/Yb vs. Ce/La diagram. This REE fractionation effect compares to redox variation, distinguishing several zones in marine deposits, according with Kunzendorf et al. (1988). I: deep-sea sediments, II: Fe-Mn nodules, III: marine basalt altered rocks, IV: seawater. The hydrothermally affected ridge sediments (HARS) according with Van der Flier-Keller (1991) is also plotted. The North Aoba Basin sediments are located in the marine basalt altered rocks in a close area from the HARS; some of the NAB sediments are in the NAB zone. The numbers refer to major elements results of Tables 8 and 9 . 

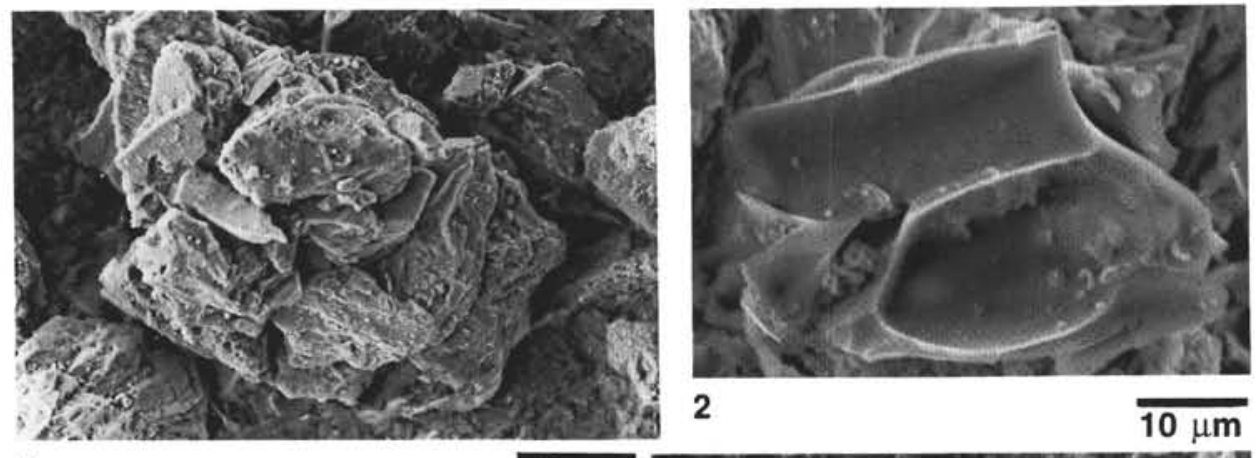

1
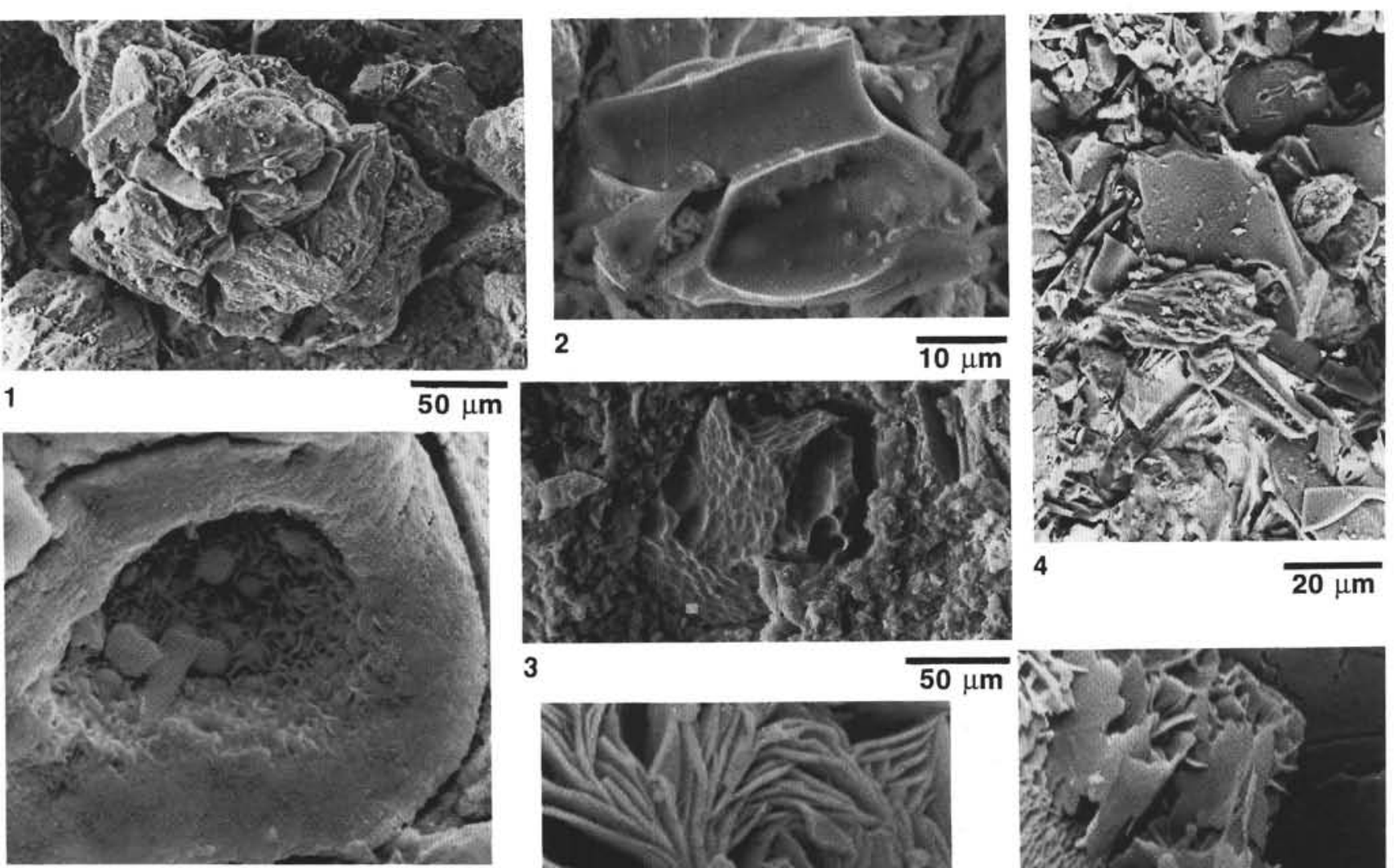

6

$\overline{5 \mu \mathrm{m}}$
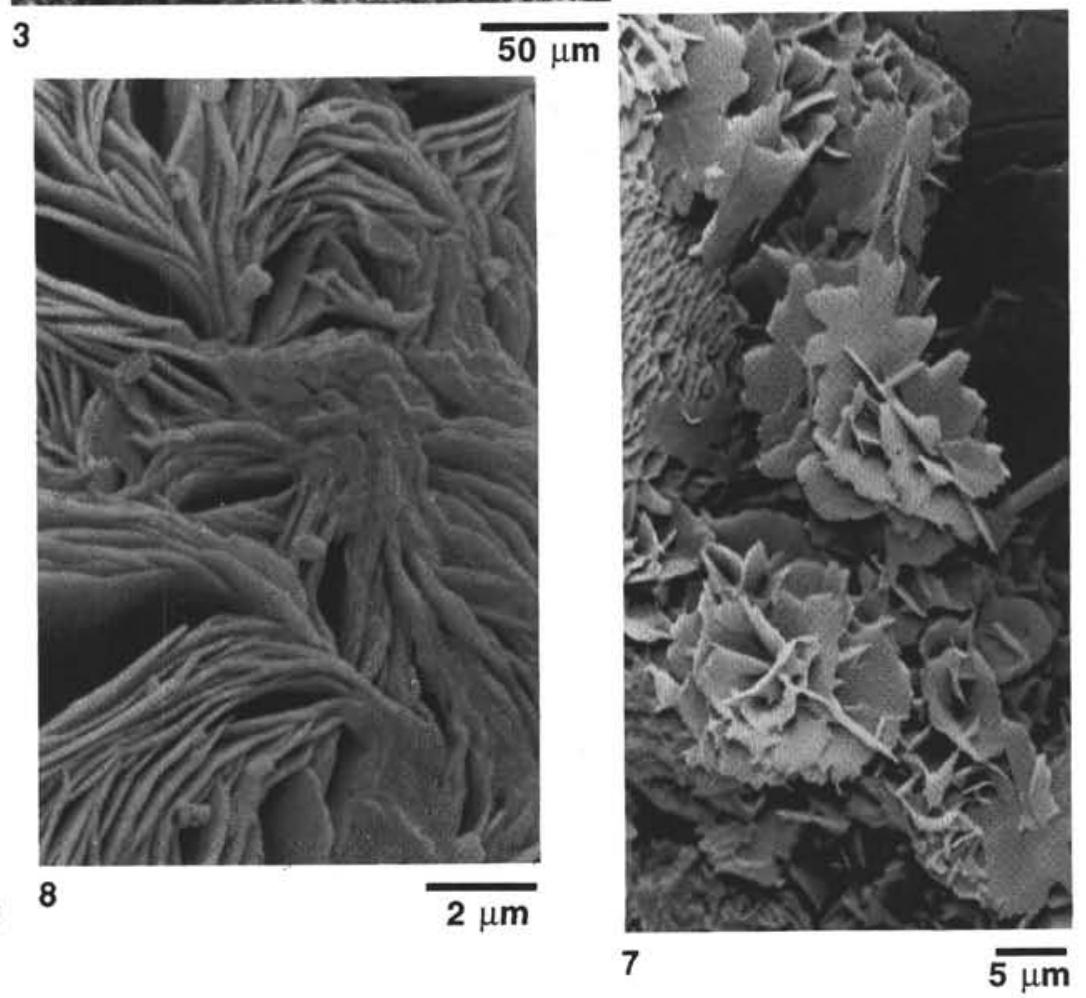

Plate 1. SEM photomicrographs of vitric particles, Site 832. 1. Sample $134-832 \mathrm{~A}-18 \mathrm{H}-1,32-33 \mathrm{~cm}, 131.82 \mathrm{mbsf}$; agglomerated vitric particle. 2. Sample 134-832A-1, 32-34 cm; cuspate glass shards. 3. Sample 134-832B-40R-2, 23-25 cm, 521.23 mbsf; vesicular glass particle in clayey matrix. 4. Sample 134-832A-19H-1, 85-87 cm, 141.85 mbsf; platy glass shards and pumice. 5. Sample 134-832B-94R-2, 102-104 cm; Fe vugs. 6. Sample 134-832B-94R-2, 102-104 cm; Fe-vugs filled with smectites overgrowth and authigenic lacite. 7. Sample 134-832B-52R-1, 35-37 cm; Fe-oxides en rosette shape. 8. Sample 134-832B-94R-2, 102-104 cm; lamellar smectites. 

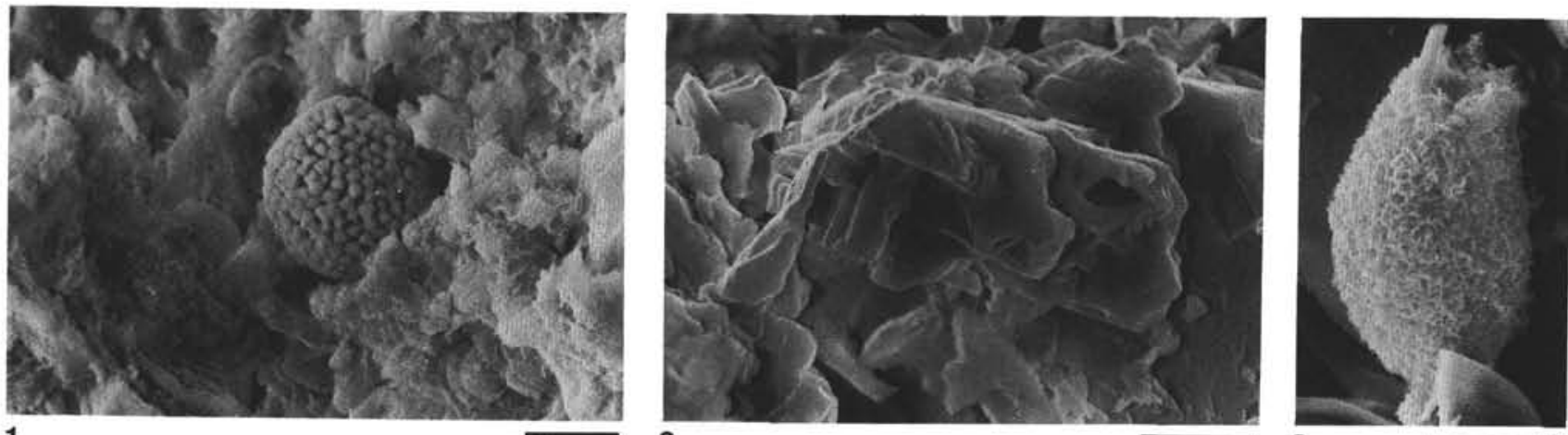

1

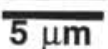

\section{2}
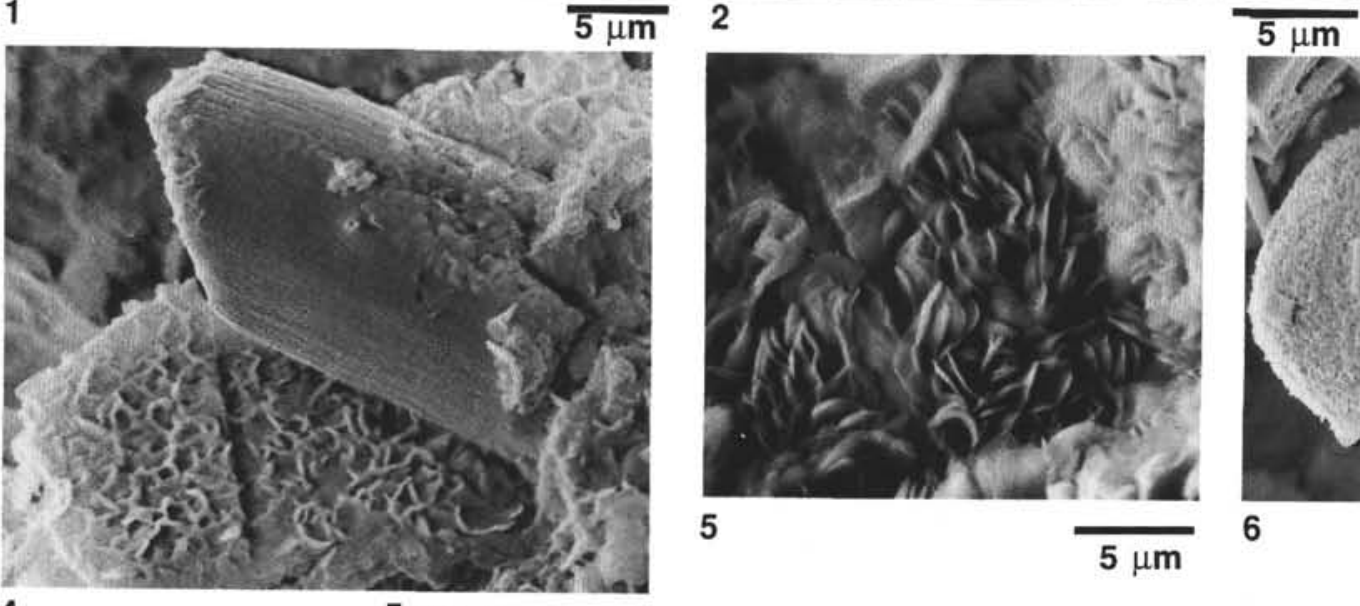

3

$10 \mu \mathrm{m}$

5

$5 \mu \mathrm{m}$

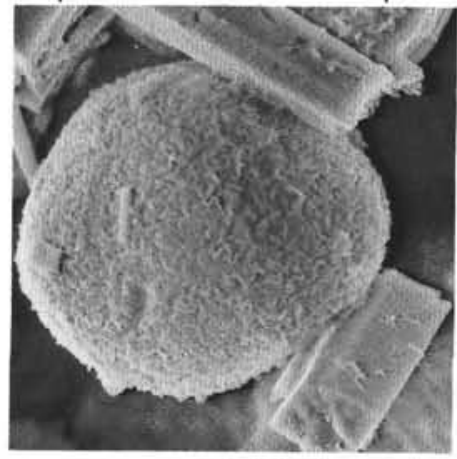

6

$5 \mu \mathrm{m}$

$5 \mu \mathrm{m}$

\section{4}

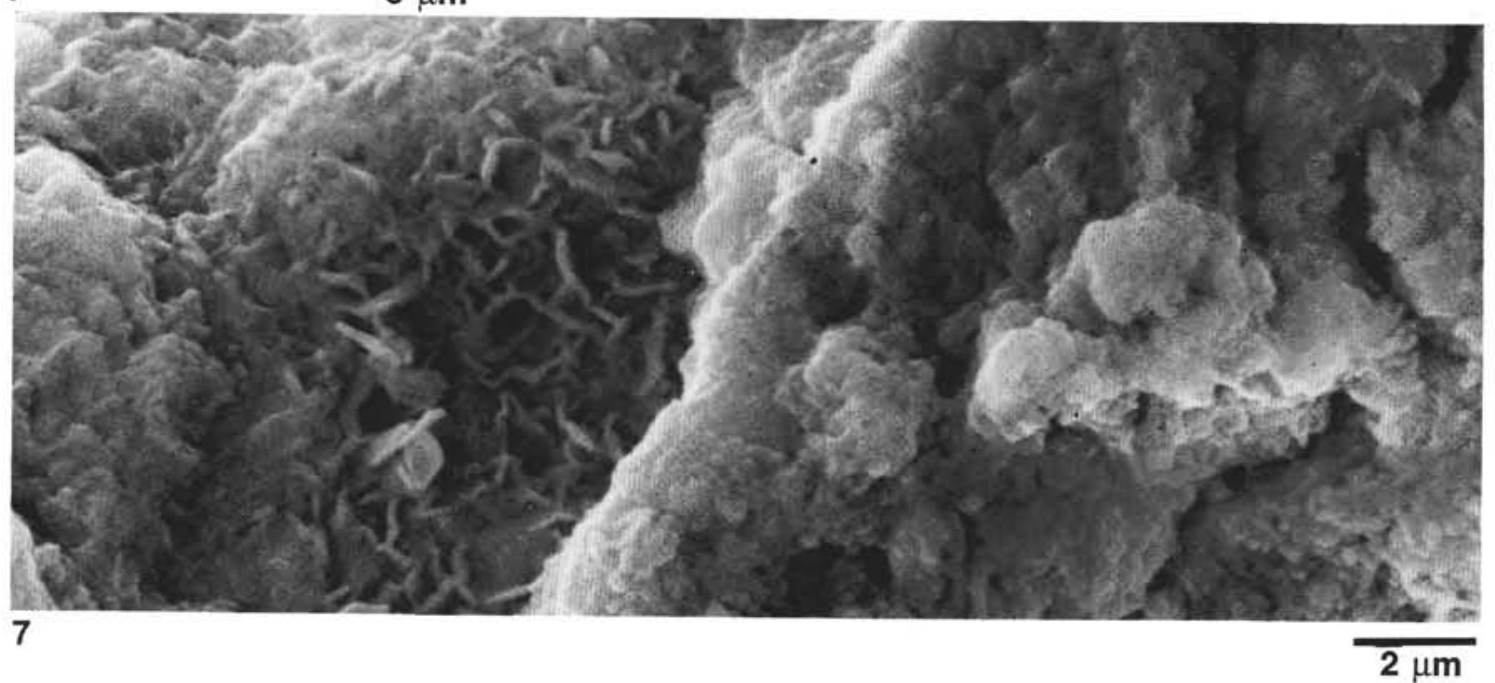

Plate 2. SEM photomicrographs of authigenic accessory minerals in smectitic levels (Hole 832B). 1. Sample 134-832B-85R-4, 17-19 cm, 957.27 mbsf; framboidal pyrite. 2. Sample 134-832B-85R-4, 17-19 cm; gypsum. 3. Sample 134-832B-36R-1, 108-110 cm, 481.88 mbsf; leucoxene (Si-Ca-Ti bearing alteration of titanomagnetite). 4. Sample 134-832B-52R-1(B), 115-117 cm; calcite monocrystal on Mg-Fe smectites. 5. Sample 832B-94R-2, 102-104 cm, 1041.52 mbsf; well-shaped lamellar Mg-Fe smectites. 6. Sample 134-832B-89R-3, 105-107 cm, 994.85 mbsf; leucoxene and Ca-plagioclases associated. 7. Sample 134-832B-89R-3, 105-107 cm; micromorphology variation of saponite. 

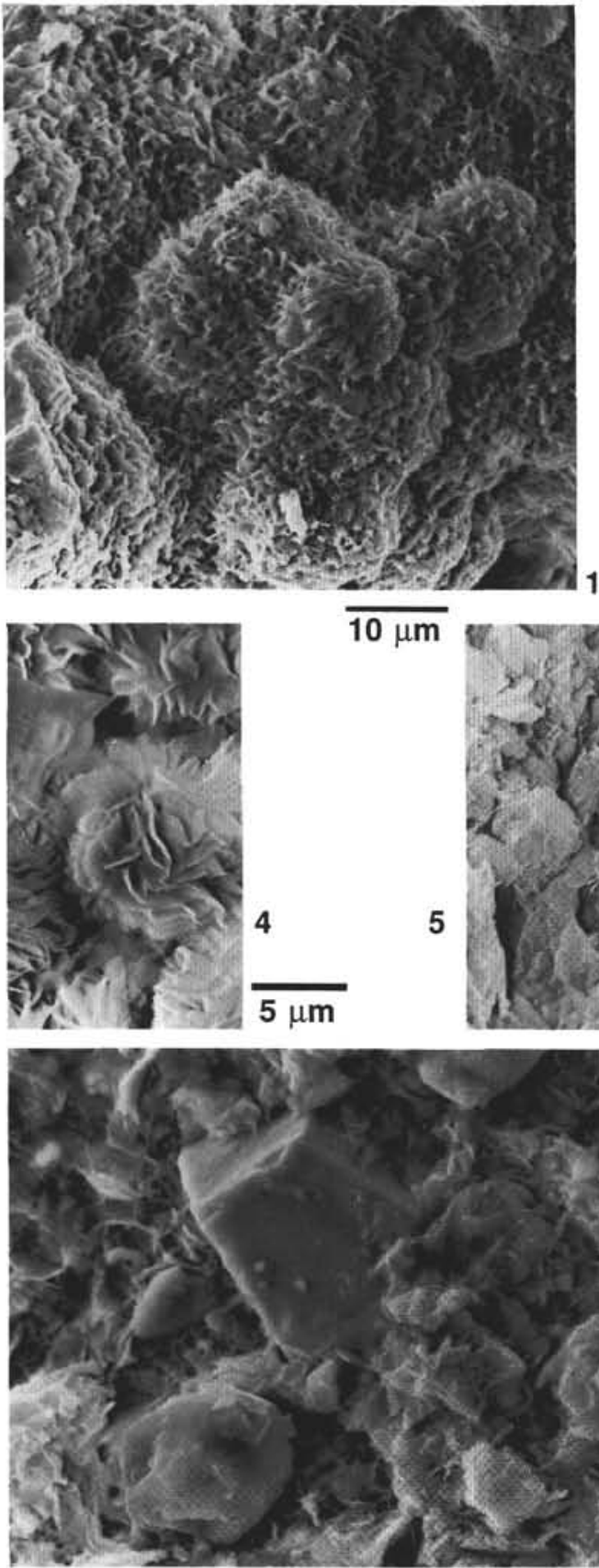

7

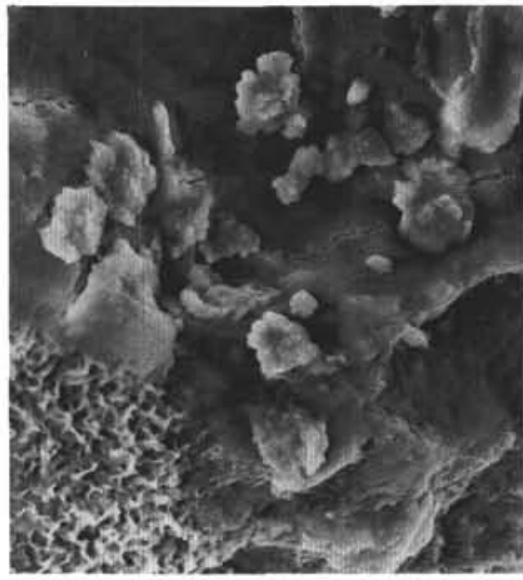

2

$10 \mu \mathrm{m}$

5

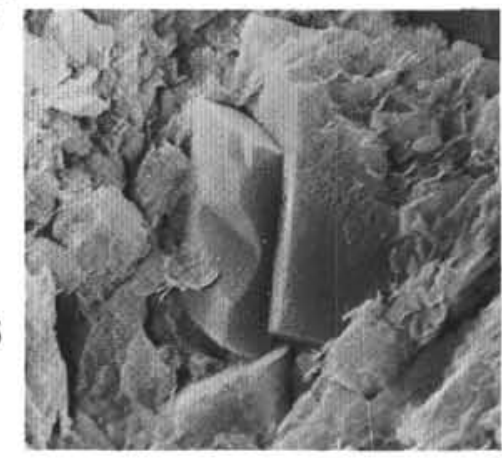

$5 \mu \mathrm{m}$
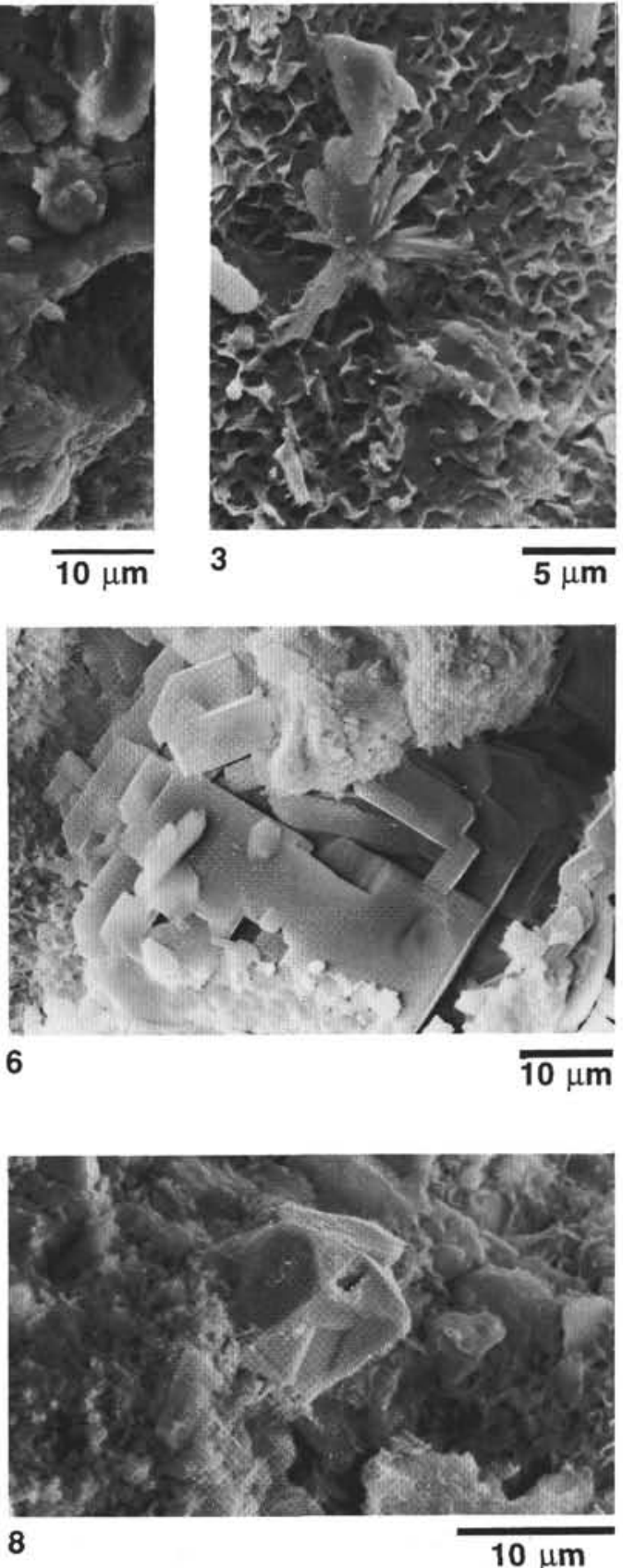

$10 \mu \mathrm{m}$

Plate 3. 1-6. SEM photomicrographs of authigenic minerals, Hole 833B. (1) Sample 134-833B-53R-1, 40-42 cm, 558.3 mbsf; nontronite globule constituted by anastomosed lamella, (2) Sample 134-833B-53R-1, 40-42 cm; growth of calcite on nontronite matrix, (3) Sample 134-833B-53R-1, 40-42 cm; flower growth of calcite on nontronite surface, (4) Sample 134-833B-53R-1, 40-42 cm; well-shaped rosette of smectite, (5) Sample 134-833B-78R, 12-14 cm, 800.62 mbsf; growing calcite monocrystals in smectitic matrix, (6) Sample 134-833B-53R-1, 40-42 cm; interrupted growth of anhydrite crystal. 7, 8. SEM photomicrographs of oxides, Hole 833B. (7) Sample 134-833B-78R-3, $46 \mathrm{~cm}, 802 \mathrm{mbsf}$; angular ti-magnetite (top) associated with analcime (bottom), in smectitic matrix, (8) Sample 134-833B-78R-3, $46 \mathrm{~cm}$; euhedral ti-magnetite. 

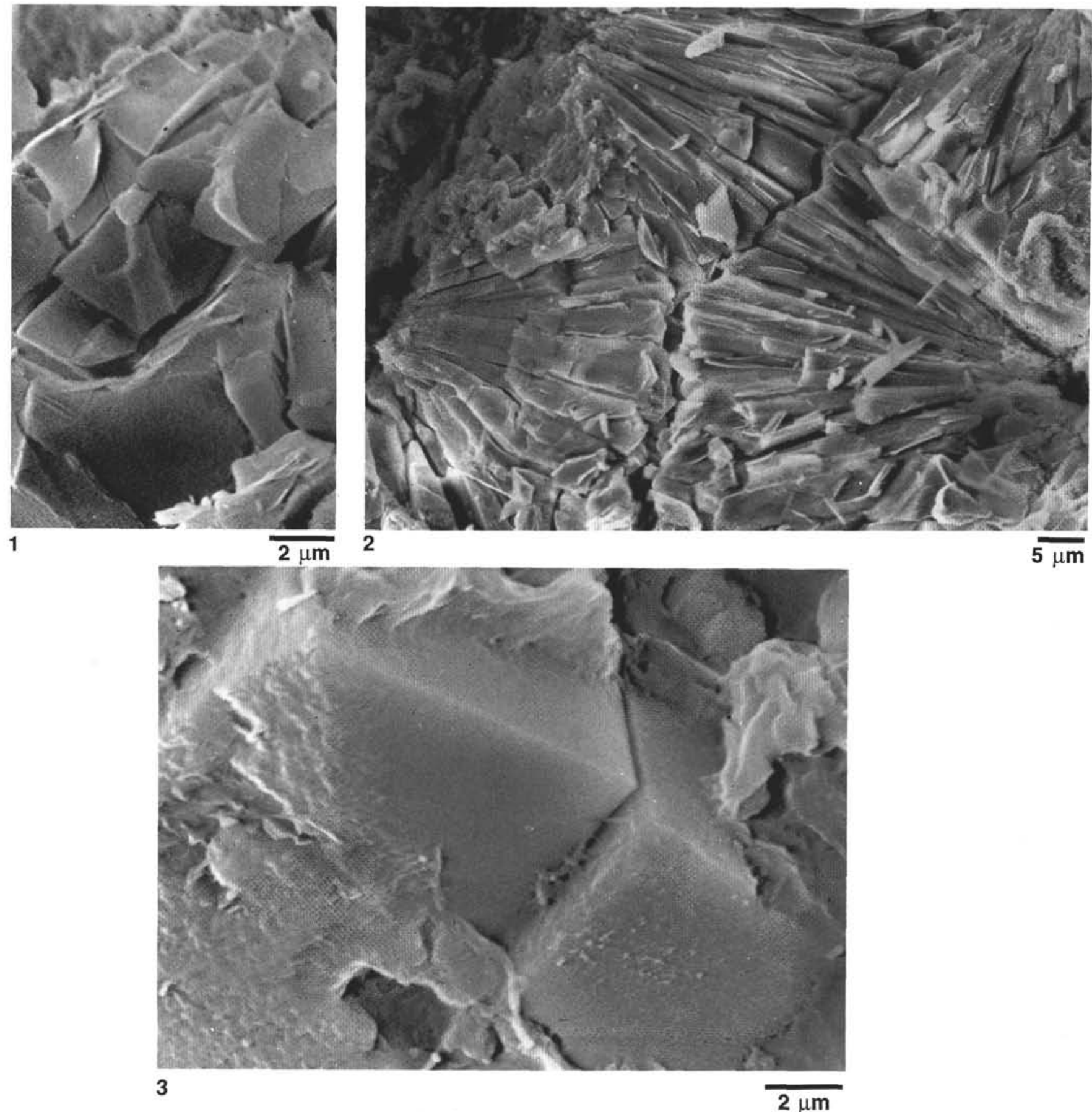

Plate 4. SEM photomicrographs of authigenic zeolites, Hole 832B. 1. Sample 134-832B-52R-1(b), 115-117 cm, 636.45 mbsf; phillipsite prisms. 2. Sample 134-832B-52R-1(b), 115-117 cm; radiating phillipsite. 3. Sample 134-832B-52R-1(b), 115-117 cm; well-formed chabazite crystals. 

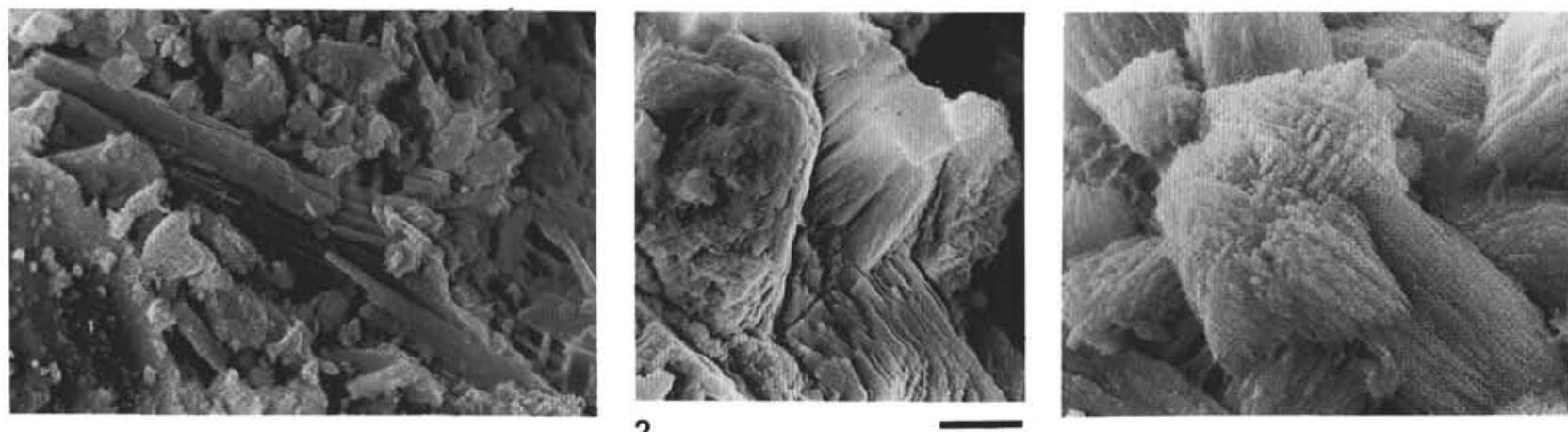

1

$5 \mu \mathrm{m}$

$\overline{5 \mu \mathrm{m}}$

$2 \mu \mathrm{m}$
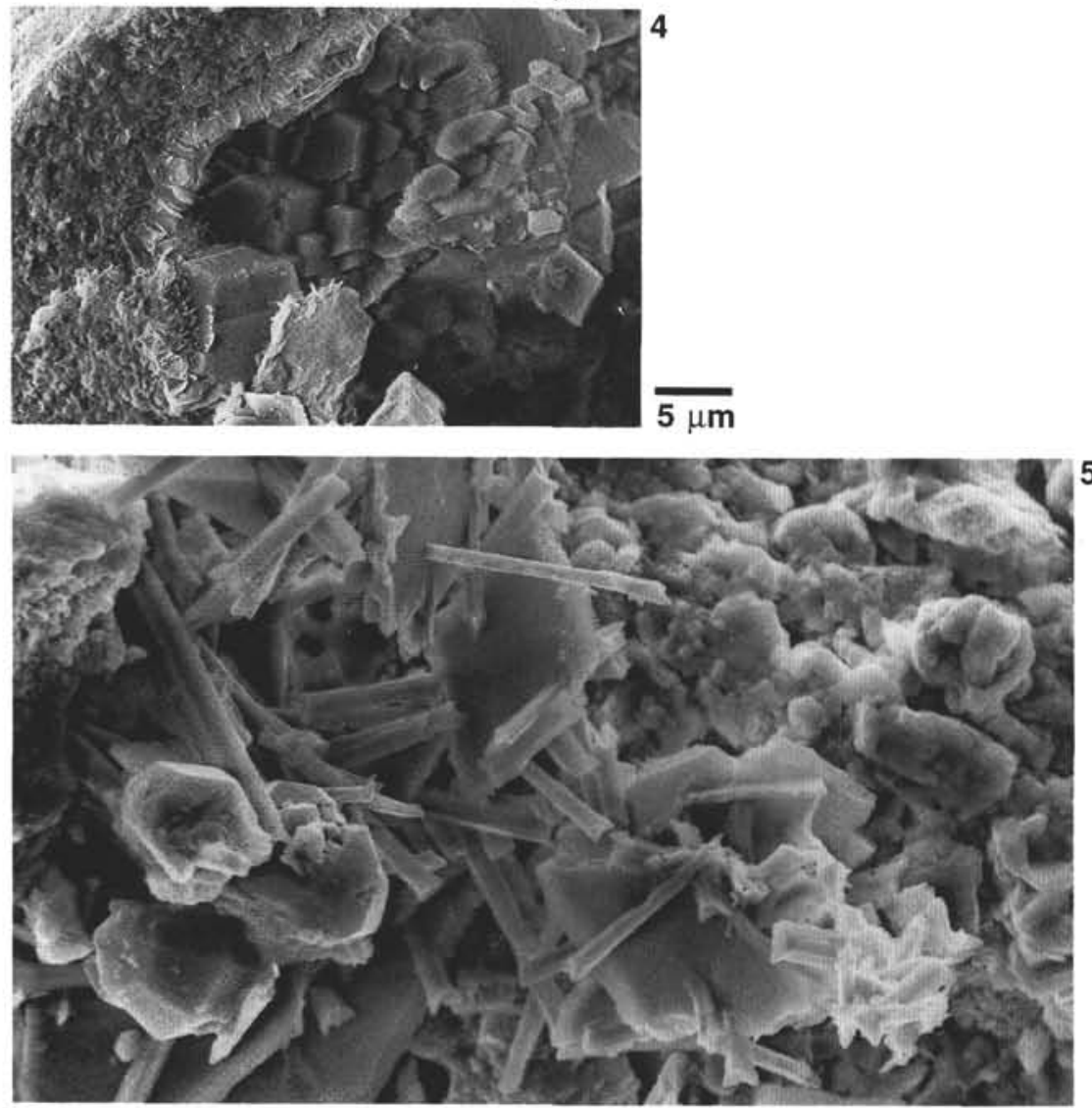

$10 \mu \mathrm{m}$

Plate 5. SEM photomicrographs: micromorphologies of authigenic erionite, Hole 832B. 1. Sample 134-832B-100R-4, $42-44 \mathrm{~cm}, 1101.92 \mathrm{mbsf}$; fibrous erionite. 2. Sample 134-832B-89R-3, 105-107 cm, 994.85 mbsf; compact bundles of fibrous erionite. 3. Sample 134-832B-36R-1, 108-110 cm, 481.88 mbsf; bundles of numerous individual needles of erionite similar to the erionite of Hector, California. 4. Sample 134-832B-94R-2, 102-104 cm, 1041.52 mbsf; smectitic coating of a vug filled by euhedral erionite. 5. Sample 134-832B-89R-3, 105-107 cm; zeolites assemblage of fibrous erionite, platy thomsonite, and euhedral analcime. 

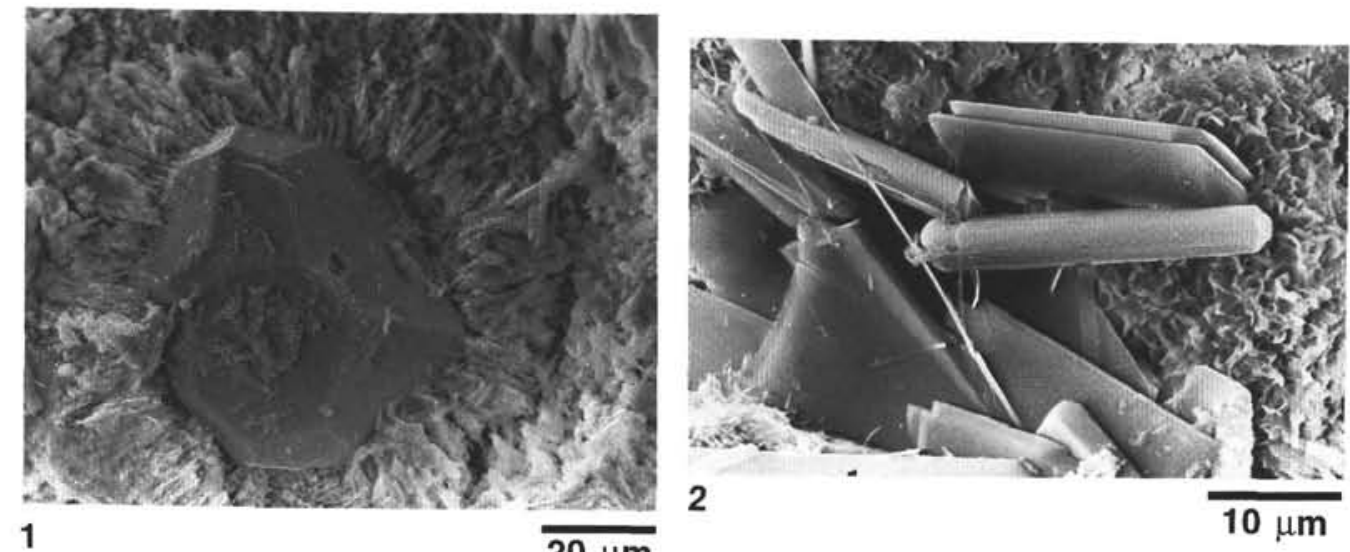

1
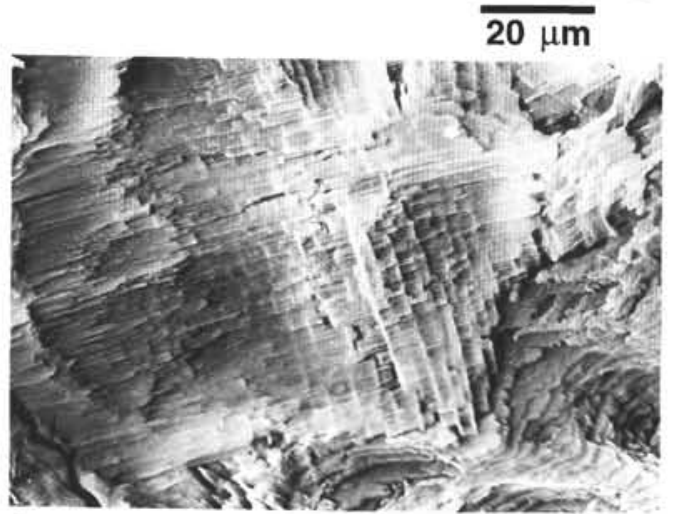

4
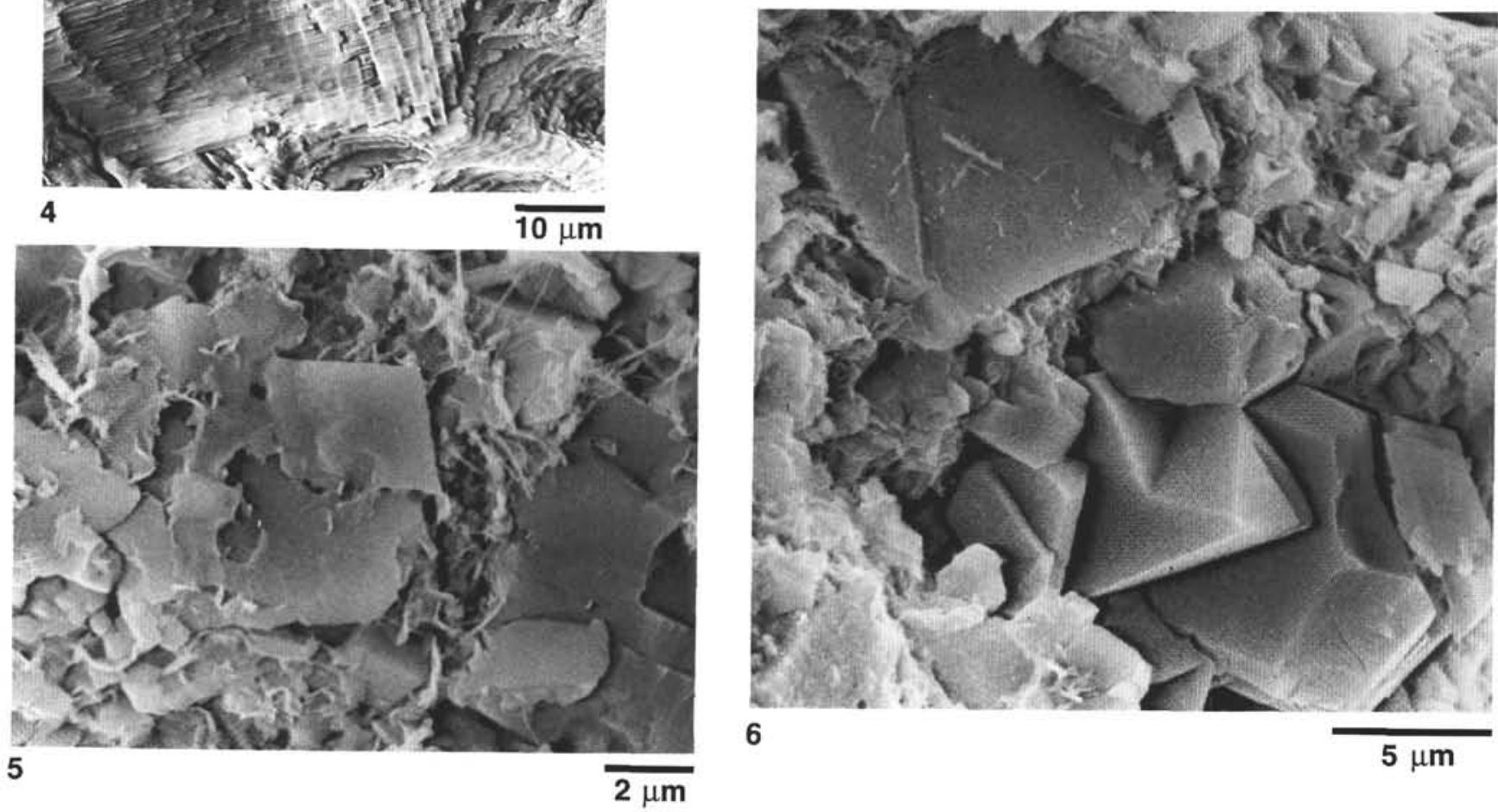

Plate 6. SEM photomicrographs of authigenic zeolites, Hole 833B. 1. Sample 134-833B-53R-1, $40-42 \mathrm{~cm}, 558.3$ mbsf; cubo-octahedral analcime monocrystal surrounding by radiating phillipsite. 2. Sample 134-833B-53R-1, 40-42 cm; lamellar thomsonite. 3. Sample 134-833B-66-R-3, 4-6 cm, 686.84 mbsf; lamellar thomsonite in saponite matrix. 4. Sample 134-833B-53R-1, 40-42 cm; parallel needles of erionite. 5. Sample 134-833B-78R-2, 12-14 cm, 800.62 mbsf; platy heulandite. 6. Sample 134-833B-78R-2, 12-14 cm; platy heulandite and well-formed phillipsite. 